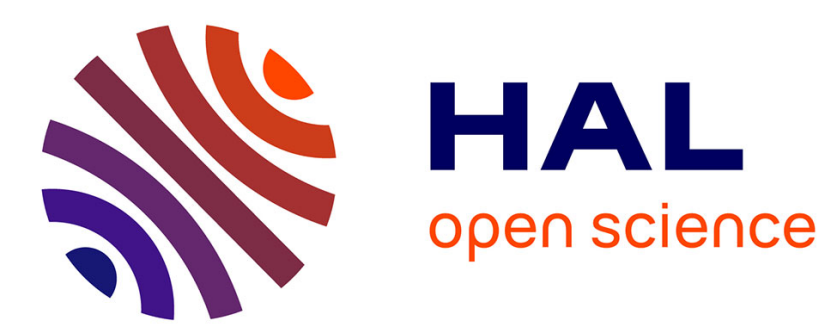

\title{
Evolution of Nucleic Acids Biosensors Detection Limit III
}

Yuan Yuan Zhang, François-Xavier Guillon, Sophie Griveau, Fethi Bedioui, Mathieu Lazerges, Cyrine Slim

\section{To cite this version:}

Yuan Yuan Zhang, François-Xavier Guillon, Sophie Griveau, Fethi Bedioui, Mathieu Lazerges, et al.. Evolution of Nucleic Acids Biosensors Detection Limit III. Analytical and Bioanalytical Chemistry, 2021, 10.1007/s00216-021-03722-9 . hal-03412677

\section{HAL Id: hal-03412677 \\ https://hal.science/hal-03412677}

Submitted on 3 Nov 2021

HAL is a multi-disciplinary open access archive for the deposit and dissemination of scientific research documents, whether they are published or not. The documents may come from teaching and research institutions in France or abroad, or from public or private research centers.
L'archive ouverte pluridisciplinaire HAL, est destinée au dépôt et à la diffusion de documents scientifiques de niveau recherche, publiés ou non, émanant des établissements d'enseignement et de recherche français ou étrangers, des laboratoires publics ou privés. 


\title{
Evolution of Nucleic Acids Biosensors Detection Limit III
}

Yuan Yuan. Zhang ${ }^{l}$, François-Xavier Guillon ${ }^{1}$, Sophie Griveau ${ }^{l}$, Fethi Bedioui $^{1}{ }^{*}$, Mathieu Lazerges $^{2}$, Cyrine Slim $^{1} *$

${ }^{1}$ Institute of Chemistry for Life and Health Sciences, Synthesis, Electrochemistry, Imaging and Analytical Systems for Diagnosis Team, Paris-Sciences-et-Lettres, CNRS, Chimie ParisTech, 11 rue Pierre et Marie Curie, 75005 Paris, France.

2 Faculté de Pharmacie de Paris, Faculté de Santé, Université de Paris, 4 avenue de l’Observatoire, 75006 Paris, France.

* fethi.bedioui@ chimieparistech.psl.eu

* cyrine.slim@chimieparistech.psl.eu

\begin{abstract}
This review is an update of two previous ones focusing on the limit of detection of electrochemical nucleic acid biosensors allowing direct detection of nucleic acid target (miRNA, mRNA, DNA) after hybridization event. A classification founded on the nature of the electrochemical transduction pathway is established. It provides an overall picture of the detection limit evolution of the various sensor architectures developed during the last three decades and a critical report of recent strategies.
\end{abstract}

Keywords. Analytical Chemistry, Biosensors, DNA, Electrochemistry, RNA.

\section{Acronyms}

\begin{tabular}{|c|c|}
\hline \multicolumn{2}{|c|}{ Electrode materials } \\
\hline $\mathrm{Au}$ & Gold \\
\hline $\mathrm{C}$ & Carbon \\
\hline Fo & Foam \\
\hline FTO & Fluorine doped Tin Oxide \\
\hline $\mathrm{GC}$ & Glassy Carbon (sp $^{2}$ carbon) \\
\hline $\mathrm{Gn}$ & Graphene \\
\hline $\mathrm{Gr}$ & Graphite \\
\hline
\end{tabular}




\begin{tabular}{|c|c|}
\hline GO & Graphene Oxide \\
\hline IDE & InterDigitated Electrode \\
\hline ILE & Ionic Liquid Electrode \\
\hline ITO & Indium Tin Oxide $\left(\mathrm{InO}_{2} / \mathrm{Sn}_{2} \mathrm{O}_{3}\right)$ \\
\hline MWNTs & Multi-Walled NanoTubes \\
\hline $\mathrm{NFs}$ & NanoFibers \\
\hline $\mathrm{NGn}$ & Nitrogen doped Graphene \\
\hline $\mathrm{NTs}$ & NanoTubes \\
\hline $\mathrm{NWs}$ & NanoWires \\
\hline $\mathrm{Pa}$ & Paste \\
\hline $\mathrm{PA}$ & Polycrylonitrile) \\
\hline $\mathrm{Pe}$ & Platinum \\
\hline $\mathrm{Pt}$ & PolyPyrrole \\
\hline $\mathrm{PEDOT}$ & Poly(3,4-EthyleneDioxyThiophene) \\
\hline $\mathrm{PPy}$ & PolyVinyl Ferrocene \\
\hline $\mathrm{PSS}$ & PolyVinyl Sulfonate \\
\hline $\mathrm{PVF}$ & Tin Oxide \\
\hline $\mathrm{PVS}$ & Screen-Printed Electrode \\
\hline $\mathrm{SnO}$ & \\
\hline $\mathrm{SPE}$ & \\
\hline
\end{tabular}

\begin{tabular}{|c|c|}
\hline \multicolumn{2}{|c|}{ Electrochemical setups } \\
\hline $2 \mathrm{E}$ & 2-electrode electrochemical cell \\
\hline $3 \mathrm{E}$ & 3-electrode electrochemical cell \\
\hline CMOS & Complementary Metal Oxide Semiconductor \\
\hline FET & Field Effect Transistor \\
\hline HEMT & High Electron Mobility Transistor \\
\hline
\end{tabular}

\begin{tabular}{|c|c|}
\hline \multicolumn{2}{|c|}{ Electrochemical techniques } \\
\hline CM & Capacity Measurement \\
\hline CP & ChronoPotentiometry \\
\hline CV & Cyclic Voltammetry \\
\hline DPV & Differential Pulsed Voltammetry \\
\hline EIS & Electrochemical Impedance Spectroscopy \\
\hline LSV & Linear Sweep Voltammetry \\
\hline SWV & Square Wave Voltammetry \\
\hline
\end{tabular}

\section{Introduction}

Nucleic acids detection for medical diagnosis is a major issue of life sciences. Nucleic acids are classically quantified by biological amplification (i.e. PCR) and subsequent fluorimetric detection. Electrochemical detection of nucleic acids provides advantages over PCR since it does not require PCR amplification and it allows direct transduction of a hybridization event conversely to optical and acoustic transduction techniques. The main limitation of electrochemical DNA-biosensors development is their high detection limit, which is beyond 
the PCR/fluorimetric assays one, and their limited reproducibility. Nevertheless, many works were performed to overcome these limitations [1,2]. This review focuses electrochemical biosensors designed by grafting nucleic acids, DNA or PNA (peptide nucleic acid), onto a solid electrode surface through physical adsorption, electrochemically assisted adsorption, chemical covalent attachment, or avidin-biotin complexation, etc., and based on a direct hybridization with a non-labelled DNA-target, with or without redox indicator. However, electrode surfaces modified with polymers or membranes useful for immobilization of capture probes are not discussed in this review.

\section{Biosensors based on direct DNA oxidation}

Hybridization event can be transduced by guanine oxidation (

Fig. 1).<smiles>C[C-](C)c1nc2c(=O)[nH]c(N)nc2[nH]1</smiles>

Fig. 1. Guanine oxidation mechanism.

The electrochemical oxidation signal increases after hybridization due to additional oxidation of the target guanine groups (Fig. 2). 

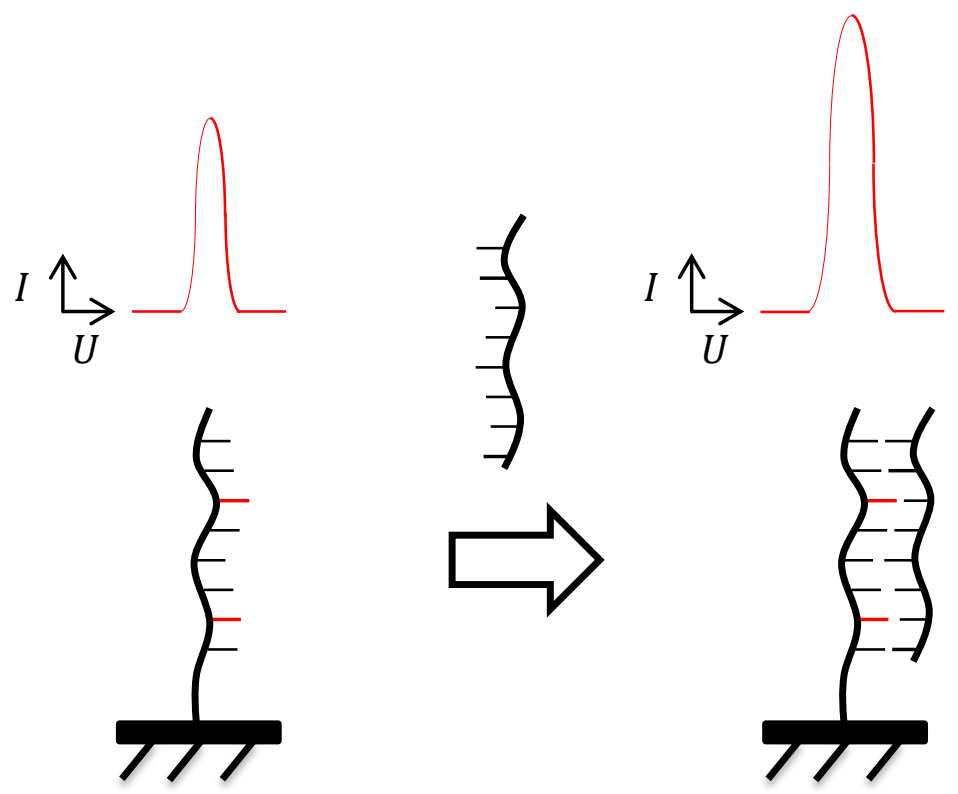

Fig. 2. Transduction based on the electrochemical oxidation of guanine (DPV) response: before (left) and after (right) hybridization (guanine groups are represented in red).

Guanine oxidation process is irreversible due to chemical reactions (i.e. proton losses) occurring after first electron transfer. The faradic oxidation charge $Q(\mathrm{C})$ of adsorbed DNA guanine is:

$$
\boldsymbol{Q}=\boldsymbol{\Gamma} \cdot \boldsymbol{F} \cdot \boldsymbol{A}[1]
$$

where $\Gamma\left(\mathrm{mol} / \mathrm{cm}^{2}\right)$ is the surface concentration of guanine onto electrode, $F(\mathrm{C} / \mathrm{mol})$ the Faraday constant and $A\left(\mathrm{~cm}^{2}\right)$ the electrode area. It is interesting to use Differential Pulsed Voltammetry (DPV) for this kind of hybridization transduction to remove the current due to the charge of the electrode-electrolyte interface capacity from the electrochemical response.

An interesting strategy was developed to increase signal/noise ratio by replacing guanine bases of an oligonucleotide probe by inosine bases that establish hydrogen bonding with $\mathrm{A}, \mathrm{T}$ and $\mathrm{C}$ bases (Fig. 3). 

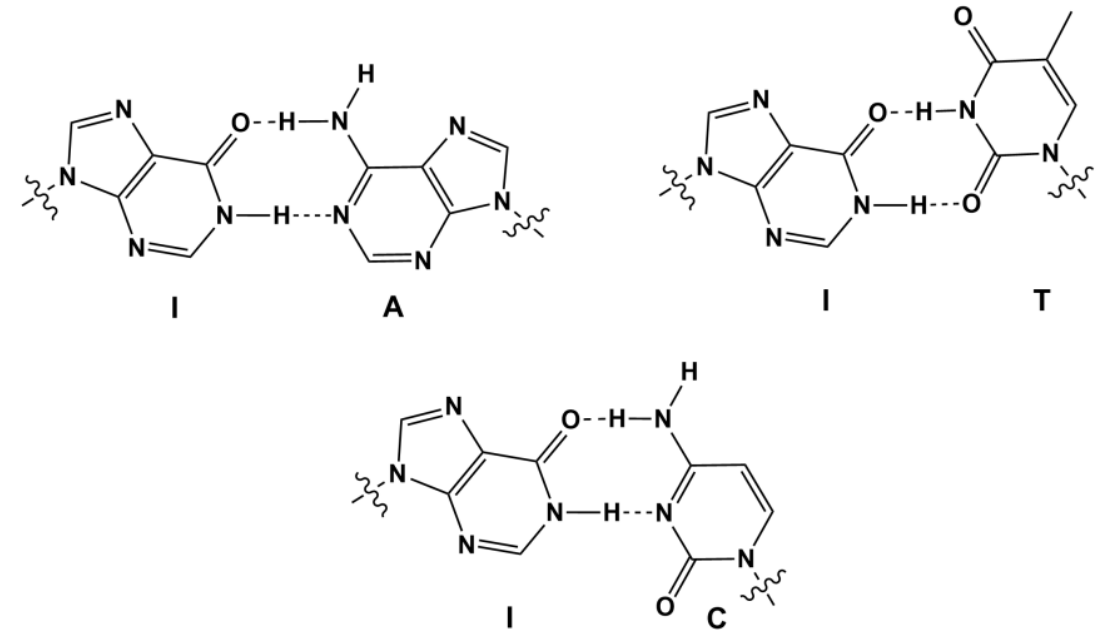

Fig. 3. Double hydrogen bonded complexes of inosine I with $\mathrm{A}, \mathrm{T}$ and $\mathrm{C}$ bases.

The inosine oxidation potential is higher than guanine one [3], thus the electrochemical response of the probe is silenced (Fig. 4).
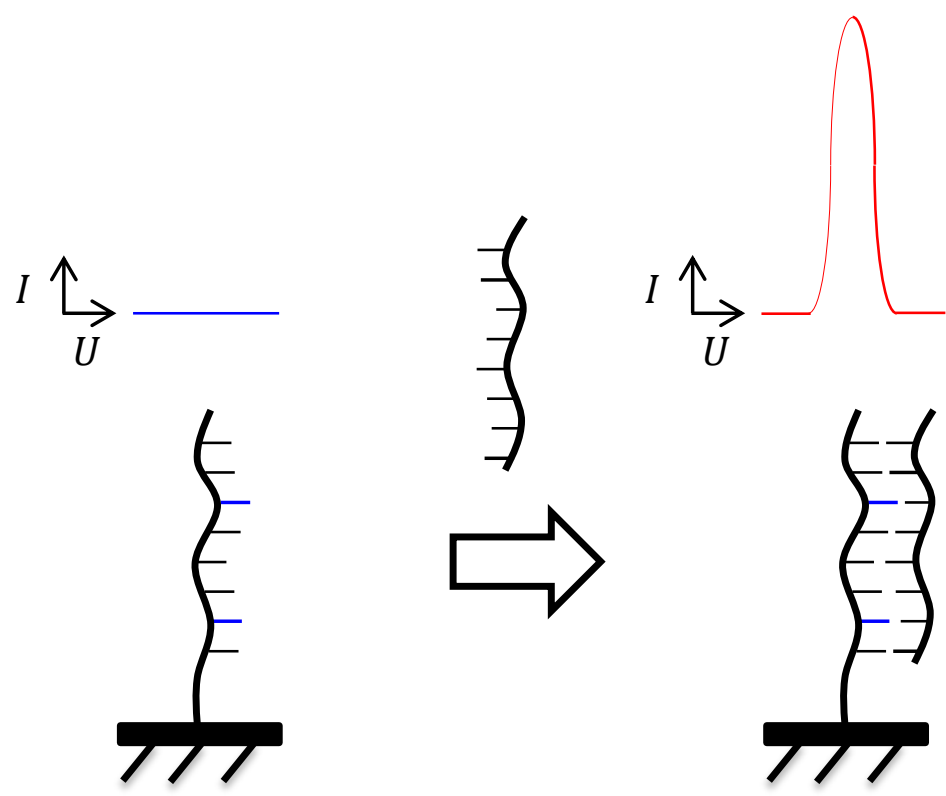

Fig. 4. Transduction based on the electrochemical oxidation of (DPV) response before (blue) and after (red) hybridization. The signal before hybridization is silenced by substitution of guanine with inosine (blue). 
A decrease of the biosensor selectivity was not mentioned by the authors, but it can be expected as the inosine, that is three orders of magnitude less reactive than guanosine, can form hydrogen bonded complexes with both $\mathrm{A}, \mathrm{T}$ and $\mathrm{C}$ bases. Anyhow, this does not constitute a shortcoming as it is possible to restore this loss of selectivity by increasing the probe size by few bases.

The performances of electrochemical DNA biosensors based on guanine oxidation are summarized in Table 1 and presented on Fig. 7.

Table 1. DNA detection limits of biosensors based on guanine oxidation.

\begin{tabular}{|c|c|c|c|c|c|c|c|c|c|}
\hline $\begin{array}{c}\text { Electrode } \\
\text { Material (Setup) }\end{array}$ & $\begin{array}{c}\text { Electrochemical } \\
\text { detection }\end{array}$ & Target & PCR & $\begin{array}{c}\text { Target } \\
\text { Volume }\end{array}$ & $\begin{array}{c}\text { Hybridization } \\
\text { time }\end{array}$ & $\begin{array}{l}\text { Mismatch } \\
\text { detection }\end{array}$ & $\begin{array}{c}\text { LOD } \\
(\mathrm{mol} / \mathrm{L})\end{array}$ & Year & Ref. \\
\hline C-Pa (3-electrode) & $\mathrm{CP}$ & $\begin{array}{l}\text { 29-base } \\
\text { DNA }\end{array}$ & No & - & $4 \min$ & - & $1.3 \cdot 10^{-8}$ & 1998 & [3] \\
\hline C-Pa (3-electrode) & $\mathrm{CV}$ & $\begin{array}{l}\text { 20-base } \\
\text { DNA }\end{array}$ & No & $10 \mu \mathrm{L}$ & $5 \mathrm{~min}$ & - & $1.0 \cdot 10^{-6}$ & 1997 & [4] \\
\hline $\begin{array}{c}\text { Gr-Pe } \\
\text { (3-electrode) }\end{array}$ & $\mathrm{CP}$ & $\begin{array}{l}\text { 19-base } \\
\text { DNA }\end{array}$ & No & $200 \mu \mathrm{L}$ & $2 \min$ & 1-base & $7.0 \cdot 10^{-8}$ & 2001 & [5] \\
\hline $\begin{array}{c}\text { C-SPE } \\
\text { (3-electrode) }\end{array}$ & SWV & $\begin{array}{l}\text { 244-base } \\
\text { DNA }\end{array}$ & Yes & $10 \mu \mathrm{L}$ & $10 \mathrm{~min}$ & 1-base & $4.0 \cdot 10^{-7}$ & 2002 & [6] \\
\hline $\mathrm{C}$-Pa (3-electrode) & DPV & $\begin{array}{l}\text { 23-base } \\
\text { DNA }\end{array}$ & Yes & $10 \mu \mathrm{L}$ & $6 \min$ & 1-base & $3.0 \cdot 10^{-9}$ & 2002 & [7] \\
\hline $\begin{array}{c}\text { Gr-PE } \\
\text { (3-electrode) }\end{array}$ & DPV & $\begin{array}{l}\text { 20-base } \\
\text { DNA }\end{array}$ & Yes & - & $15 \mathrm{~min}$ & 1-base & $5.0 \cdot 10^{-10}$ & 2005 & [8] \\
\hline $\begin{array}{l}\text { Gr-PE/C-NTs } \\
\text { (3-electrode) }\end{array}$ & DPV & $\begin{array}{l}\text { 20-base } \\
\text { DNA }\end{array}$ & No & $20 \mu \mathrm{L}$ & $20 \mathrm{~min}$ & - & $1.6 \cdot 10^{-8}$ & 2006 & [9] \\
\hline $\begin{array}{l}\mathrm{Pt} / \mathrm{PPy} / \mathrm{PVS} \\
\text { (3-electrode) }\end{array}$ & DPV & $\begin{array}{c}\text { 25-base } \\
\text { DNA }\left(G_{25}\right)\end{array}$ & No & - & $30 \mathrm{~s}$ & - & $1.0 \cdot 10^{-17}$ & 2007 & {$[10]$} \\
\hline $\begin{array}{c}\mathrm{Gr} / \mathrm{SnO}_{2}-\mathrm{NPs} / \mathrm{PVF} \\
\text { (3-electrode) }\end{array}$ & DPV & $\begin{array}{l}\text { 20-base } \\
\text { DNA }\end{array}$ & No & - & $30 \mathrm{~min}$ & 1-base & $3.0 \cdot 10^{-7}$ & 2010 & [11] \\
\hline $\begin{array}{c}\mathrm{Gr}-\mathrm{Pe} \\
\text { (3-electrode) }\end{array}$ & DPV & $\begin{array}{l}\text { 121-base } \\
\text { DNA }\end{array}$ & Yes & $2.5 \mu \mathrm{L}$ & $10 \mathrm{~min}$ & - & $1.0 \cdot 10^{-15}$ & 2011 & {$[12]$} \\
\hline $\begin{array}{c}\mathrm{Gr}-\mathrm{Pe} \\
\text { (3-electrode) }\end{array}$ & $\mathrm{CV}$ & $\begin{array}{l}\text { 500-base } \\
\text { DNA }\end{array}$ & No & - & $15 \mathrm{~min}$ & - & $3.9 \cdot 10^{-7}$ & 2014 & {$[13]$} \\
\hline $\begin{array}{c}\text { Gr-Pe/C-MWNTs } \\
\text { (3-electrode) }\end{array}$ & DPV & $\begin{array}{l}\text { 16-base } \\
\text { DNA }\end{array}$ & Yes & $30 \mu \mathrm{L}$ & $20 \mathrm{~min}$ & - & $1.7 \cdot 10^{-8}$ & 2017 & {$[14]$} \\
\hline $\begin{array}{c}\text { Gr-Pe/GO } \\
\text { (3-electrode) }\end{array}$ & DPV & $\begin{array}{l}\text { 20-base } \\
\text { DNA }\end{array}$ & No & $1 \mathrm{~mL}$ & $30 \mathrm{~min}$ & - & $4.3 \cdot 10^{-11}$ & 2017 & {$[15]$} \\
\hline $\begin{array}{c}\text { Gr-Pe/GO } \\
\text { (3-electrode) }\end{array}$ & DPV & $\begin{array}{l}\text { 22-base } \\
\text { miRNA }\end{array}$ & No & $40 \mu \mathrm{L}$ & $60 \mathrm{~min}$ & - & $1.1 \cdot 10^{-6}$ & 2017 & {$[16]$} \\
\hline $\begin{array}{l}\text { Gr-Pe/PA-NFs } \\
\text { (3-electrode) }\end{array}$ & DPV & $\begin{array}{l}\text { 18-base } \\
\text { DNA }\end{array}$ & No & $75 \mu \mathrm{L}$ & $30 \mathrm{~min}$ & 1-base & $3.7 \cdot 10^{-8}$ & 2018 & [17] \\
\hline $\begin{array}{c}\text { Gr-Pe/GO } \\
\text { (3-electrode) }\end{array}$ & DPV & $\begin{array}{l}\text { 22-base } \\
\text { miRNA }\end{array}$ & No & $100 \mu \mathrm{L}$ & $60 \mathrm{~min}$ & - & $7.0 \cdot 10^{-7}$ & 2018 & [18] \\
\hline $\begin{array}{l}\text { C-Pa/Ag-NPs } \\
\text { (3-electrode) }\end{array}$ & EIS & $\begin{array}{l}\text { 22-base } \\
\text { miRNA }\end{array}$ & No & - & $30 \mathrm{~min}$ & - & $1.0 \cdot 10^{-18}$ & 2018 & [19] \\
\hline $\begin{array}{c}\text { Gr-Pe } \\
\text { (3-electrode) }\end{array}$ & DPV & $\begin{array}{l}\text { 28-base } \\
\text { DNA }\end{array}$ & Yes & $200 \mu \mathrm{L}$ & $30 \mathrm{~min}$ & - & $2.1 \cdot 10^{-8}$ & 2018 & [20] \\
\hline $\begin{array}{c}\text { C-SPE } \\
\text { (3-electrode) }\end{array}$ & DPV & $\begin{array}{l}\text { 23-base } \\
\text { DNA }\end{array}$ & Yes & $10 \mu \mathrm{L}$ & $15 \mathrm{~min}$ & - & $1.2 \cdot 10^{-6}$ & 2019 & {$[21]$} \\
\hline $\mathrm{Gr}-\mathrm{Pe}$ & DPV & 22-base & No & $40 \mu \mathrm{L}$ & $30 \mathrm{~min}$ & 2-base & $8.0 \cdot 10^{-8}$ & 2019 & [22] \\
\hline
\end{tabular}




\begin{tabular}{c|c|c|c|c|c|c|c|c|c}
\hline $\begin{array}{c}\text { (3-electrode) } \\
\text { C-Pa/C-NTs/Au-NP } \\
\mathrm{s}(3 \text {-electrode) }\end{array}$ & DPV & $\begin{array}{c}\text { miRNA } \\
\begin{array}{c}22 \text {-base } \\
\text { miRNA }\end{array}\end{array}$ & No & - & $30 \mathrm{~min}$ & 1 -base & $4.7 \cdot 10^{-15}$ & 2019 & {$[23]$} \\
\hline $\begin{array}{c}\text { GO/PEDOT/PSS } \\
\text { (3-electrode) }\end{array}$ & DPV & $\begin{array}{c}21 \text {-base } \\
\text { DNA }\end{array}$ & No & - & $30 \mathrm{~min}$ & $\begin{array}{c}1,2,3,4-\text { bas } \\
\text { e }\end{array}$ & $1.5 \cdot 10^{-14}$ & 2020 & {$[24]$} \\
\hline
\end{tabular}

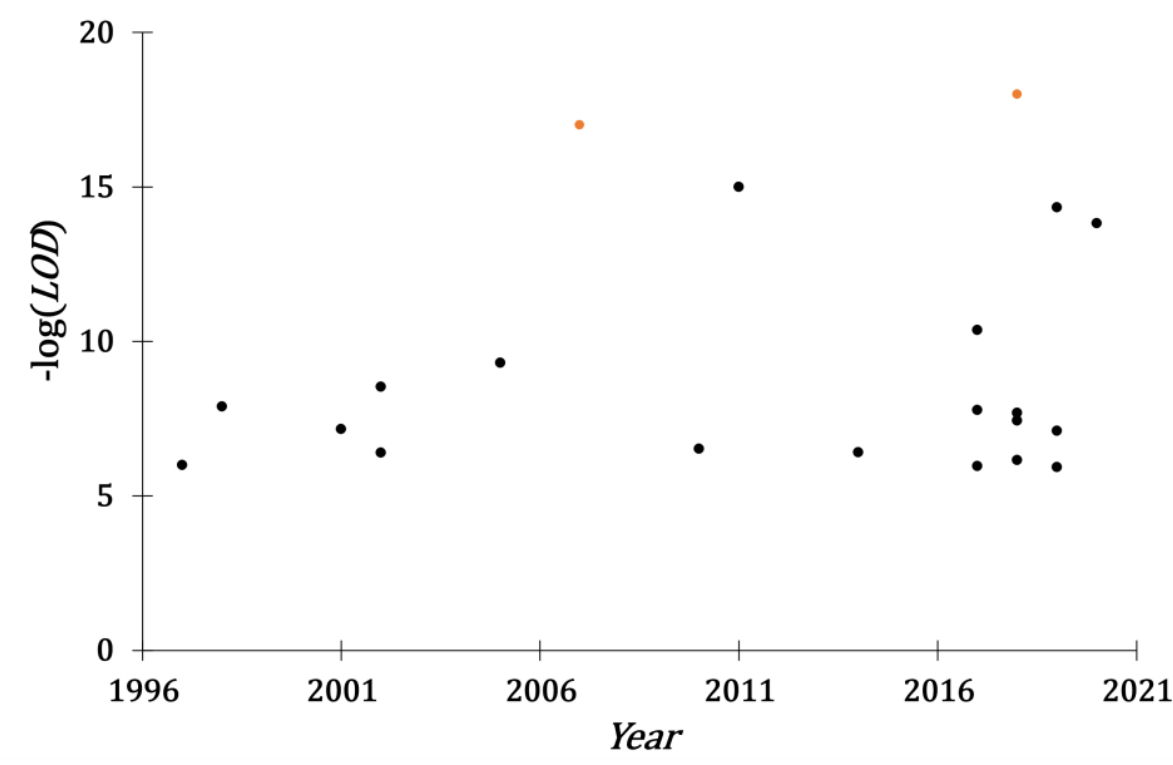

Fig. 5. $L O D$ evolution of electrochemical DNA-biosensors based on guanine oxidation.

Orange circles: attomolar detection limit but sample volume not indicated.

Since 1997, only five studies have reported a LOD in the femtomolar range, unfortunately, the analytical sample volume was not mentioned for the two studies with the lowest LODs. The LOD obtained are too high to detect genomic DNAs or messenger RNAs without PCR amplification but enough low to direct detection of abundant miRNAs. The LOD obtained using carbon paste electrodes (CPE) and screen-printed electrodes (SPE) are high $\left(10^{-8} \mathrm{M}\right)$. The utilization of materials like pencil electrodes (PE) and nanomaterials (such as Au-NPs) immobilized onto electrode surface allows to reach lower LODs $\left(10^{-15} \mathrm{M}\right)$.

\section{Non-Faradaic Biosensors}

Transduction can be based on the modification of the electrical properties of the electrode-electrolyte interface due to hybridization: both electrical conductivity and capacity of the interface are changed during hybridization. This kind of transduction is interesting because it does not require redox species and because DNA -probe and -target are not damaged during the measurement, allowing repeating hybridization with the same biosensor. The variation of the interfacial capacity can be measured by transient electrochemical 
techniques like electrochemical impedance spectroscopy (EIS), or linear sweep (LSV) and cyclic voltammetry (CV) (Fig. 6).
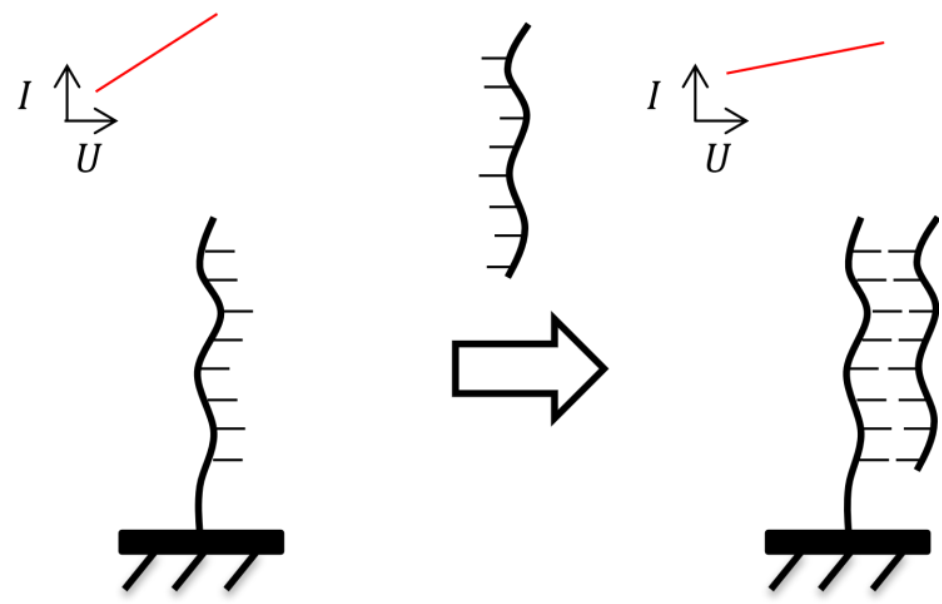

Fig. 6. Electrochemical transduction of DNA hybridization of non-faradic biosensor: linear sweep voltammetry response.

Transient electrochemical techniques allow the separation of ohmic and capacitive responses of the interface. The $L O D$ reported for these transduction pathways are summarized in Table 2 and presented on Fig. 7.

Table 2. DNA detection limit of non-faradaic biosensors.

\begin{tabular}{|c|c|c|c|c|c|c|c|c|c|}
\hline $\begin{array}{l}\text { Electrode } \\
\text { (setup) }\end{array}$ & $\begin{array}{c}\text { Electrochemical } \\
\text { detection }\end{array}$ & Target & PCR & $\begin{array}{l}\text { Target } \\
\text { Volume }\end{array}$ & $\begin{array}{c}\text { Hybridization } \\
\text { time }\end{array}$ & $\begin{array}{l}\text { Mismatch } \\
\text { detection }\end{array}$ & $\begin{array}{c}\text { LOD } \\
(\mathrm{mol} / \mathrm{L})\end{array}$ & Year & Ref. \\
\hline $\begin{array}{c}\mathrm{Si} / 4-\mathrm{ABDMMS} \\
\text { (3-electrode) }\end{array}$ & EIS & $\begin{array}{c}\text { 30-base } \\
\text { DNA }\left(\mathrm{A}_{30}\right)\end{array}$ & Yes & $50 \mu \mathrm{L}$ & - & - & $1.0 \cdot 10^{-10}$ & 2000 & [25] \\
\hline Au (3-electrode) & EIS & $\begin{array}{l}\text { 26-base } \\
\text { DNA }\end{array}$ & No & - & $15 \mathrm{~min}$ & - & $1.0 \cdot 10^{-9}$ & 2003 & [26] \\
\hline $\begin{array}{c}\mathrm{CdIn}_{2} \mathrm{O}_{4} \\
\text { semi-conductor } \\
\text { (3-electrode) }\end{array}$ & EIS & $\begin{array}{l}20 \text {-base } \\
\text { DNA }\end{array}$ & No & No & $45 \mathrm{~min}$ & - & $1.3 \cdot 10^{-11}$ & 2006 & [27] \\
\hline Au (3-electrode) & EIS & $\begin{array}{l}\text { 27-base } \\
\text { DNA }\end{array}$ & No & $20 \mu \mathrm{L}$ & $5 \mathrm{~min}$ & - & $1.0 \cdot 10^{-14}$ & 2008 & [28] \\
\hline $\begin{array}{c}\mathrm{Au} / \mathrm{SDD}-\mathrm{Co}(\mathrm{II}) \\
\text { (3-electrode) }\end{array}$ & EIS & $\begin{array}{l}\text { 21-base } \\
\text { DNA }\end{array}$ & No & $250 \mu \mathrm{L}$ & $45 \mathrm{~min}$ & - & $3.4 \cdot 10^{-13}$ & 2010 & [29] \\
\hline $\begin{array}{c}\text { Au/PAMAM/G } \\
\text { aNNWs } \\
\text { (3-electrode) }\end{array}$ & EIS & $\begin{array}{c}\text { 24-base } \\
\text { DNA }\end{array}$ & No & - & $120 \mathrm{~min}$ & 1,3-base & $1.0 \cdot 10^{-19}$ & 2013 & [30] \\
\hline $\begin{array}{c}\text { GC/AuNps/PPy } \\
\text { (3-electrode) }\end{array}$ & EIS & $\begin{array}{l}\text { 20-base } \\
\text { DNA }\end{array}$ & No & $7 \mu \mathrm{L}$ & $40 \mathrm{~min}$ & 1,2-base & $8.4 \cdot 10^{-13}$ & 2014 & [31] \\
\hline $\begin{array}{c}\text { RGO-FET } \\
\text { (3-electrode) }\end{array}$ & $\mathrm{CP}$ & $\begin{array}{l}\text { 22-base } \\
\text { DNA }\end{array}$ & No & - & $60 \mathrm{~min}$ & 1-base & $1.0 \cdot 10^{-13}$ & 2014 & [32] \\
\hline $\begin{array}{c}\mathrm{SiO}_{2}-\mathrm{IDE} \\
\mathrm{CMOS} \\
\text { (2-electrode) }\end{array}$ & $\mathrm{CM}$ & $\begin{array}{l}\text { 20-base } \\
\text { DNA }\end{array}$ & No & - & - & - & $1.0 \cdot 10^{-17}$ & 2017 & [33] \\
\hline $\begin{array}{c}\text { Au-IDE } \\
\text { (2-electrode) }\end{array}$ & $\mathrm{CM}$ & $\begin{array}{l}\text { 24-base } \\
\text { DNA }\end{array}$ & No & $20 \mu \mathrm{L}$ & $30 \mathrm{~min}$ & - & $1.5 \cdot 10^{-18}$ & 2017 & [34] \\
\hline Al-IDE & EIS & 28-base & No & $10 \mu \mathrm{L}$ & $30 \mathrm{~s}$ & - & $1.0 \cdot 10^{-17}$ & 2017 & [35] \\
\hline
\end{tabular}




\begin{tabular}{|c|c|c|c|c|c|c|c|c|c|}
\hline (2-electrode) & & DNA & & & & & & & \\
\hline $\begin{array}{c}\text { Gr-FET } \\
\text { (3-electrode) }\end{array}$ & $\mathrm{CP}$ & $\begin{array}{l}\text { 26-base } \\
\text { DNA }\end{array}$ & No & - & - & 1-base & $1.0 \cdot 10^{-11}$ & 2017 & [36] \\
\hline $\begin{array}{l}\text { C-NTs-FET } \\
\text { (3-electrode) }\end{array}$ & $\mathrm{CA}$ & $\begin{array}{c}\text { 24-base } \\
\text { DNA }\end{array}$ & No & - & $120 \mathrm{~min}$ & - & $1.0 \cdot 10^{-12}$ & 2017 & [37] \\
\hline $\begin{array}{c}\text { CNT-FET } \\
\text { (3-electrode) }\end{array}$ & $\mathrm{CA}$ & $\begin{array}{l}\text { 21-base } \\
\text { DNA }\end{array}$ & No & - & $1 \mathrm{~min}$ & - & $1.0 \cdot 10^{-12}$ & 2017 & [38] \\
\hline $\begin{array}{c}\text { AAO-FET } \\
\text { (3-electrode) }\end{array}$ & $\mathrm{CP}$ & $\begin{array}{l}\text { 10-base } \\
\text { DNA }\end{array}$ & No & - & $90 \mathrm{~min}$ & 1,2-base & $1.0 \cdot 10^{-10}$ & 2017 & [39] \\
\hline $\begin{array}{c}\text { Gr-FET } \\
\text { (3-electrode) }\end{array}$ & $\mathrm{CP}$ & $\begin{array}{c}\text { 15-base } \\
\text { DNA }\end{array}$ & No & - & - & - & $1.0 \cdot 10^{-13}$ & 2018 & [40] \\
\hline $\begin{array}{c}\mathrm{MoS}_{2} \text {-FET } \\
\text { (3-electrode) }\end{array}$ & $\mathrm{CA}$ & $\begin{array}{l}\text { 22-base } \\
\text { DNA }\end{array}$ & No & - & $60 \mathrm{~min}$ & 1,3-base & $6.0 \cdot 10^{-15}$ & 2018 & [41] \\
\hline $\begin{array}{c}\text { NiO-FET } \\
\text { (3-electrode) }\end{array}$ & $\mathrm{CA}$ & $\begin{array}{l}\text { 21-base } \\
\text { DNA }\end{array}$ & No & $20 \mu \mathrm{L}$ & $30 \mathrm{~min}$ & 2-base & $3.0 \cdot 10^{-19}$ & 2018 & [42] \\
\hline $\begin{array}{l}\text { ITO NWs-FET } \\
\text { (3-electrode) }\end{array}$ & $\mathrm{CA}$ & $\begin{array}{l}\text { 21-base } \\
\text { DNA }\end{array}$ & No & $6 \mu \mathrm{L}$ & $90 \mathrm{~min}$ & 1-base & $1.0 \cdot 10^{-15}$ & 2018 & [43] \\
\hline $\begin{array}{c}\text { Gr-FET } \\
\text { (3-electrode) }\end{array}$ & $\mathrm{CP}$ & $\begin{array}{l}\text { 15-base } \\
\text { DNA }\end{array}$ & No & - & $300 \mathrm{~min}$ & - & $1.0 \cdot 10^{-16}$ & 2018 & [44] \\
\hline $\begin{array}{c}\mathrm{MoS}_{2} \text {-FET } \\
\text { (3-electrode) }\end{array}$ & $\mathrm{CA}$ & $\begin{array}{l}\text { 23-base } \\
\text { miRNA }\end{array}$ & No & $20 \mu \mathrm{L}$ & $40 \mathrm{~min}$ & 1-base & $3.0 \cdot 10^{-17}$ & 2018 & [45] \\
\hline $\begin{array}{c}\text { Au/AuNPs } \\
\text { (3-electrode) }\end{array}$ & EIS & $\begin{array}{l}\text { 22-base } \\
\text { miRNA }\end{array}$ & No & - & $50 \mathrm{~min}$ & - & $2.0 \cdot 10^{-12}$ & 2018 & [46] \\
\hline $\begin{array}{c}\mathrm{Al} / \mathrm{p}-\mathrm{Si} / \mathrm{SiO}_{2} / \mathrm{PA} \\
\mathrm{H} \text { EIS chip } \\
\text { (2-electrode) }\end{array}$ & EIS & $\begin{array}{l}\text { 72-base } \\
\text { DNA }\end{array}$ & Yes & $50 \mu \mathrm{L}$ & $40 \min$ & - & $3.0 \cdot 10^{-10}$ & 2018 & [47] \\
\hline $\begin{array}{c}\text { GaN } \\
\text { /AlGaN-HEMT } \\
\text { (3-electrode) }\end{array}$ & CA & $\begin{array}{l}\text { 22-base } \\
\text { DNA }\end{array}$ & No & $20 \mu \mathrm{L}$ & $3 \min$ & 1,2-base & $1.0 \cdot 10^{-15}$ & 2018 & [48] \\
\hline $\begin{array}{c}\text { Gr-FET } \\
\text { (3-electrode) }\end{array}$ & $\mathrm{CA}$ & $\begin{array}{l}\text { 16-base } \\
\text { DNA }\end{array}$ & No & $50 \mu \mathrm{L}$ & $45 \mathrm{~min}$ & - & $1.0 \cdot 10^{-15}$ & 2019 & [49] \\
\hline $\begin{array}{c}\text { CeO2 NRs/Ppy } \\
\text { NPs } \\
\text { (3-electrode) }\end{array}$ & EIS & $\begin{array}{l}\text { 26-base } \\
\text { DNA }\end{array}$ & No & - & - & 1,2,3-base & $2.9 \cdot 10^{-7}$ & 2019 & [50] \\
\hline $\begin{array}{c}\mathrm{MoS}_{2} \text {-FET } \\
\text { (3-electrode) }\end{array}$ & $\mathrm{CA}$ & $\begin{array}{c}\text { 30-base } \\
\text { DNA }\end{array}$ & No & $60 \mu \mathrm{L}$ & $60 \mathrm{~min}$ & 3-base & $1.0 \cdot 10^{-16}$ & 2019 & [51] \\
\hline $\begin{array}{l}\mathrm{Al} / \mathrm{p}-\mathrm{Si} / \mathrm{SiO} 2 / \mathrm{P} \\
\mathrm{AH} \text { EIS chip } \\
\text { (2-electrode) }\end{array}$ & EIS & $\begin{array}{l}\text { 72-base } \\
\text { DNA }\end{array}$ & No & $100 \mu \mathrm{L}$ & $40 \min$ & - & $1.0 \cdot 10^{-10}$ & 2019 & [52] \\
\hline $\begin{array}{c}\text { Gr-FET } \\
\text { (3-electrode) }\end{array}$ & $\mathrm{CP}$ & $\begin{array}{l}\text { 15-base } \\
\text { DNA }\end{array}$ & No & - & $300 \mathrm{~min}$ & - & $1.0 \cdot 10^{-19}$ & 2020 & [53] \\
\hline $\begin{array}{l}\mathrm{SiO}_{2} \text {-ISFET } \\
\text { (3-electrode) }\end{array}$ & EIS & $\begin{array}{c}\text { 21-base } \\
\text { DNA }\end{array}$ & No & - & - & - & $1.0 \cdot 10^{-10}$ & 2020 & [54] \\
\hline $\begin{array}{c}\text { Gr-FET } \\
\text { (3-electrode) }\end{array}$ & $\mathrm{CP}$ & $\begin{array}{l}\text { 20-base } \\
\text { miRNA }\end{array}$ & No & $1 \mu \mathrm{L}$ & $20 \mathrm{~min}$ & - & $1.0 \cdot 10^{-14}$ & 2020 & [55] \\
\hline $\begin{array}{c}\text { ITO/GA } \\
\text { (3-electrode) }\end{array}$ & EIS & $\begin{array}{c}\text { 24-base } \\
\text { DNA }\end{array}$ & No & $10 \mu \mathrm{L}$ & $10 \mathrm{~min}$ & - & $1.4 \cdot 10^{-15}$ & 2020 & [56] \\
\hline $\begin{array}{l}\text { Au- EGFET } \\
\text { (3-electrode) }\end{array}$ & EIS & $\begin{array}{c}\text { 26-base } \\
\text { DNA }\end{array}$ & No & - & $30 \mathrm{~min}$ & - & $9.8 \cdot 10^{-13}$ & 2021 & [57] \\
\hline $\begin{array}{l}\text { OTFT- FET } \\
\text { (3-electrode) }\end{array}$ & $\mathrm{CA}$ & $\begin{array}{l}\text { 24-base } \\
\text { miRNA }\end{array}$ & No & $100 \mu \mathrm{L}$ & $240 \mathrm{~min}$ & 1-base & $1.0 \cdot 10^{-20}$ & 2021 & [58] \\
\hline $\begin{array}{l}\text { ITO/SnO } / \text { /rGO } \\
\text { N/PANHS-FET }\end{array}$ & $\mathrm{CA}$ & $\begin{array}{l}\text { 22-base } \\
\text { miRNA }\end{array}$ & Yes & - & $20 \mathrm{~min}$ & 1-base & $1.0 \cdot 10^{-14}$ & 2021 & [59] \\
\hline
\end{tabular}




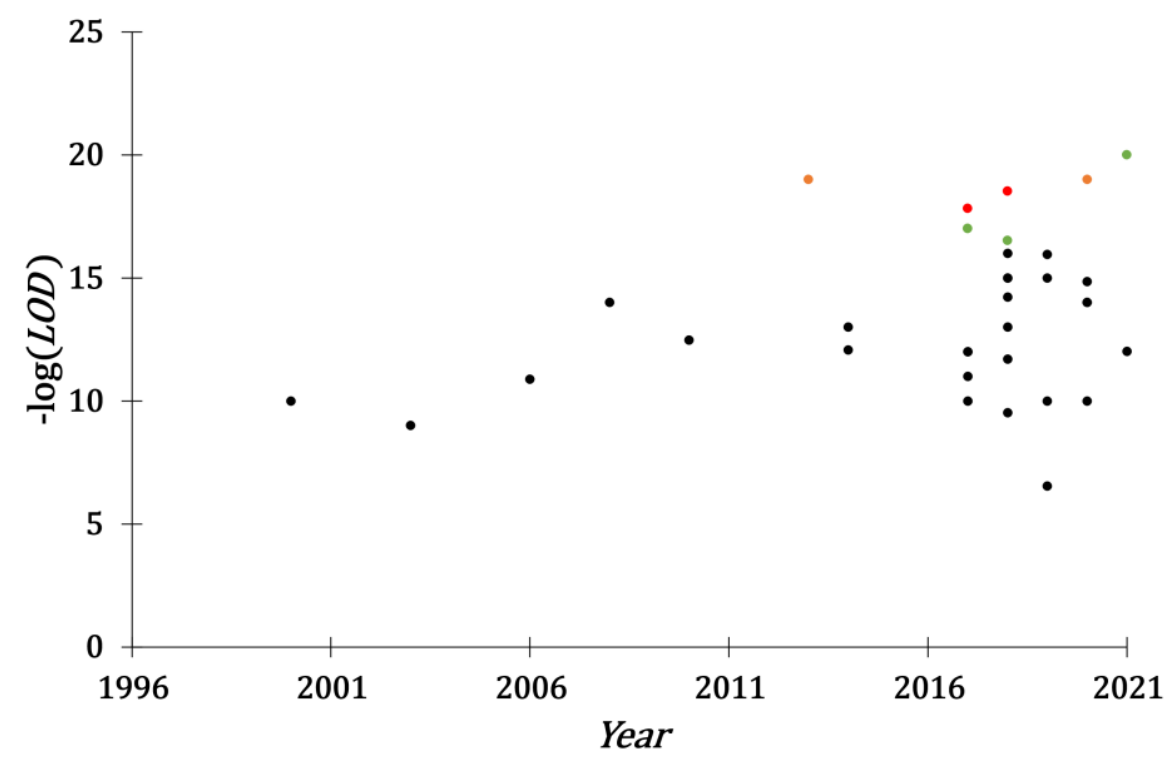

Fig. 7. $L O D$ evolution of non-faradaic biosensors. Green: attomolar LOD. Orange: attomolar LOD but sample volume not mentioned. Red: attomolar detection but dilution of nucleic acid sample beyond Avogadro number.

Ten studies reported a LOD in the femtomolar range, eight studies a LOD in the attomolar range and the lower reported LOD is equal to $10^{-20} \mathrm{~mol} / \mathrm{L}$. It is interesting to note that most of the lowest LOD are obtained for semiconducting materials: the space charge layer of a semiconductor is drastically modified during adsorption of nucleic acid targets (negative charge) due to the low concentration of charge carriers, yielding to an important modification of interface electric impedance. In the case of a metallic conductor, the concentration of charge carriers in the space charge layer is very high yielding to a feeble modification of electric properties of the interface.

\section{Biosensors based on redox probe labeling}

The principle of this transduction is based on the measurement of the redox response of a DNA-probe labeled with an electroactive molecule, in a classic or hairpin configurations (Fig. 8). 
$\stackrel{j \uparrow}{\longrightarrow}$
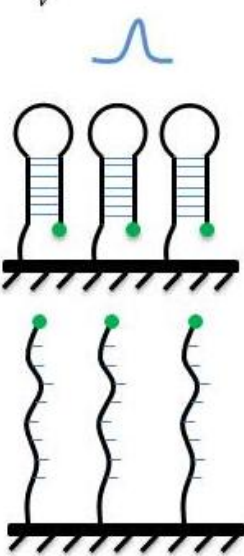
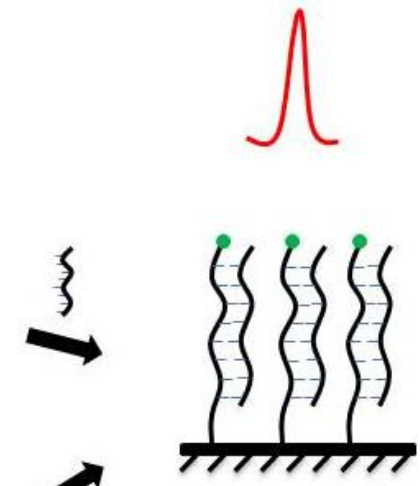

Fig. 8. Illustration of redox probe electrochemical transduction pathway with classic (left, bottom) and hairpin (left, top) DNA-probes tagged with redox groups (green circle symbols): Linear Sweep Voltammetry (LSV) responses.

The electrochemical response is due to reversible oxidation of the redox probe:

$$
\boldsymbol{Q}=\boldsymbol{\Gamma} \cdot \boldsymbol{F} \cdot \boldsymbol{A}[1]
$$

$\Gamma\left(\mathrm{mol} / \mathrm{cm}^{2}\right)$ is the surface concentration of redox probes onto electrode, $F(\mathrm{C} / \mathrm{mol})$ the Faraday constant and $A\left(\mathrm{~cm}^{2}\right)$ the electrode area. In the case of a hairpin configuration, the current can increase or decrease depending on the nature of the transduction and on the DNA-probe sequence. This transduction pathway is focused on detection of short DNA targets. If a hairpin probe is used, single mismatch detection can be achieved if the hairpin duplex is more stable than the hairpin-mismatched target duplex. Compared with the classical configuration DNA-probe, the hairpin configuration DNA-probe can distinguish single mismatch well and can be used for real-time monitoring of hybridization [60, 61]. The LOD reported for this kind of transduction pathway are summarized in Table 3 and presented on Fig. 9. Tagging a DNA-probe with a redox group adds one step more to the probe synthesis. Also, such probes are expensive to produce as they require two chemical modifications, for both surface anchoring and redox monitoring functions. 
Table 3. Detection limit of electrochemical DNA-biosensors based on redox probe labeling.

\begin{tabular}{|c|c|c|c|c|c|c|c|c|c|}
\hline $\begin{array}{l}\text { Electrode } \\
\text { (setup) }\end{array}$ & $\begin{array}{c}\text { Electrochemical } \\
\text { detection }\end{array}$ & Target & PCR & $\begin{array}{c}\text { Target } \\
\text { Volume }\end{array}$ & $\begin{array}{c}\text { Hybridization } \\
\text { time }\end{array}$ & $\begin{array}{c}\text { Mismatch } \\
\text { detection }\end{array}$ & $\begin{array}{c}\text { LOD } \\
(\mathrm{mol} / \mathrm{L})\end{array}$ & Year & Ref. \\
\hline $\begin{array}{l}\text { GC/chitosan } \\
\text { (3-electrode) }\end{array}$ & DPV & $\begin{array}{l}\text { 256-base } \\
\text { DNA }\end{array}$ & No & $1 \mathrm{~mL}$ & $60 \mathrm{~min}$ & - & $2.0 \cdot 10^{-9}$ & 2001 & [62] \\
\hline $\begin{array}{c}\mathrm{Au} \\
\text { (3-electrode) }\end{array}$ & $\mathrm{CV}$ & $\begin{array}{l}\text { 27-base } \\
\text { DNA }\end{array}$ & No & $500 \mu \mathrm{L}$ & $30 \mathrm{~min}$ & - & $1.0 \cdot 10^{-11}$ & 2003 & [63] \\
\hline $\begin{array}{c}\mathrm{Au} \\
\text { (3-electrode) }\end{array}$ & $\mathrm{CV}$ & $\begin{array}{l}\text { 24-base } \\
\text { DNA }\end{array}$ & No & $2 \mu \mathrm{L}$ & $60 \mathrm{~min}$ & 1-base & $1.0 \cdot 10^{-13}$ & 2006 & [64] \\
\hline $\begin{array}{c}\mathrm{Au} \\
\text { (3-electrode) }\end{array}$ & $\mathrm{CV}$ & $\begin{array}{l}\text { 15-base } \\
\text { DNA }\end{array}$ & No & $5 \mu \mathrm{L}$ & $60 \mathrm{~min}$ & 1-base & $2.0 \cdot 10^{-10}$ & 2007 & [65] \\
\hline $\begin{array}{c}\mathrm{Au} \\
\text { (3-electrode) }\end{array}$ & DPV & $\begin{array}{l}\text { 28-base } \\
\text { DNA }\end{array}$ & No & $12 \mu \mathrm{L}$ & $120 \mathrm{~min}$ & - & $1.0 \cdot 10^{-9}$ & 2011 & [66] \\
\hline $\begin{array}{c}\mathrm{Au} \\
\text { (3-electrode) }\end{array}$ & $\mathrm{CV}$ & $\begin{array}{l}\text { 17-base } \\
\text { DNA }\end{array}$ & No & $100 \mu \mathrm{L}$ & $60 \mathrm{~min}$ & - & $2.0 \cdot 10^{-8}$ & 2014 & [67] \\
\hline $\begin{array}{c}\mathrm{Au} \\
\text { (3-electrode) }\end{array}$ & DPV & $\begin{array}{c}\text { 27-base } \\
\text { DNA }\end{array}$ & No & $5 \mu \mathrm{L}$ & $120 \mathrm{~min}$ & 1,3-base & $7.4 \cdot 10^{-16}$ & 2015 & [68] \\
\hline $\begin{array}{c}\mathrm{Au} \\
\text { (3-electrode) }\end{array}$ & $\mathrm{CV}$ & $\begin{array}{l}\text { 18-base } \\
\text { DNA }\end{array}$ & No & - & $60 \mathrm{~min}$ & 1,3-base & $1.7 \cdot 10^{-18}$ & 2016 & [69] \\
\hline $\begin{array}{c}\mathrm{Au} \\
\text { (3-electrode) }\end{array}$ & DPV & $\begin{array}{l}\text { 18-base } \\
\text { DNA }\end{array}$ & No & $20 \mu \mathrm{L}$ & $45 \mathrm{~min}$ & 1-base & $6.0 \cdot 10^{-14}$ & 2017 & [70] \\
\hline $\begin{array}{c}\mathrm{Au} \\
\text { (3-electrode) }\end{array}$ & DPV & $\begin{array}{l}\text { 14-base } \\
\text { DNA }\end{array}$ & No & - & $40 \mathrm{~min}$ & 1,3-base & $2.3 \cdot 10^{-12}$ & 2017 & [71] \\
\hline $\begin{array}{c}\mathrm{Au} \\
\text { (3-electrode) }\end{array}$ & $\mathrm{CV}$ & $\begin{array}{l}\text { 25-base } \\
\text { DNA }\end{array}$ & No & $10 \mu \mathrm{L}$ & $63 \mathrm{~min}$ & - & $5.0 \cdot 10^{-9}$ & 2017 & [72] \\
\hline $\begin{array}{l}\text { C-SP/G-PANI } \\
\text { (3-electrode) }\end{array}$ & SWV & $\begin{array}{l}\text { 14-base } \\
\text { DNA }\end{array}$ & Yes & $3 \mu \mathrm{L}$ & $15 \mathrm{~min}$ & - & $2.3 \cdot 10^{-9}$ & 2017 & [73] \\
\hline $\begin{array}{c}\mathrm{Au} \\
\text { (3-electrode) }\end{array}$ & DPV & $\begin{array}{l}\text { 21-base } \\
\text { DNA }\end{array}$ & No & $5 \mu \mathrm{L}$ & $30 \mathrm{~min}$ & - & $7.0 \cdot 10^{-10}$ & 2017 & [74] \\
\hline $\begin{array}{c}\text { GC/AuNPs } \\
\text { (3-electrode) }\end{array}$ & LSV & $\begin{array}{l}\text { 22-base } \\
\text { miRNA }\end{array}$ & No & $50 \mu \mathrm{L}$ & $30 \mathrm{~min}$ & 1,3-base & $2.0 \cdot 10^{-17}$ & 2017 & [75] \\
\hline $\begin{array}{c}\text { Au microchip } \\
\text { array } \\
\text { (3-electrode) }\end{array}$ & $\mathrm{CV}$ & $\begin{array}{l}\text { 27-base } \\
\text { DNA }\end{array}$ & No & $5 \mu \mathrm{L}$ & $20 \mathrm{~min}$ & - & $2.5 \cdot 10^{-13}$ & 2017 & [76] \\
\hline $\begin{array}{c}\text { ITO/PET } \\
\text { (3-electrode) }\end{array}$ & DPV & $\begin{array}{l}\text { 22-base } \\
\text { miRNA }\end{array}$ & No & $3 \mu \mathrm{L}$ & $30 \mathrm{~min}$ & - & $5.0 \cdot 10^{-9}$ & 2018 & [77] \\
\hline $\begin{array}{c}\text { Au-Cys } \\
\text { (3-electrode) }\end{array}$ & DPV & $\begin{array}{l}\text { 28-base } \\
\text { DNA }\end{array}$ & Yes & $2.5 \mu \mathrm{L}$ & $30 \mathrm{~min}$ & - & $1.5 \cdot 10^{-10}$ & 2018 & [78] \\
\hline $\begin{array}{c}\text { Gr-PE/CB/Au } \\
\text { NPs } \\
\text { (3-electrode) }\end{array}$ & DPV & $\begin{array}{l}\text { 22-base } \\
\text { miRNA }\end{array}$ & No & $100 \mu \mathrm{L}$ & $30 \mathrm{~min}$ & 3-base & $1.0 \cdot 10^{-15}$ & 2019 & [79] \\
\hline $\begin{array}{c}\mathrm{Au} \\
\text { (3-electrode) }\end{array}$ & $\mathrm{CV}$ & $\begin{array}{l}\text { 22-base } \\
\text { miRNA }\end{array}$ & No & $200 \mu \mathrm{L}$ & $10 \mathrm{~min}$ & 1-base & $1.7 \cdot 10^{-16}$ & 2020 & [80] \\
\hline Au(3-electrode & DPV & $\begin{array}{l}\text { 27-base } \\
\text { DNA }\end{array}$ & No & - & - & 1-base & $7.4 \cdot 10^{-16}$ & 2020 & [81] \\
\hline $\begin{array}{c}\mathrm{Au}(3-\mathrm{electrode} \\
)\end{array}$ & DPV & $\begin{array}{l}\text { 18-base } \\
\text { DNA }\end{array}$ & No & $100 \mu \mathrm{L}$ & $45 \mathrm{~min}$ & 1,3-base & $1.1 \cdot 10^{-16}$ & 2021 & [82] \\
\hline $\begin{array}{c}\mathrm{Au} \\
\text { (3-electrode) }\end{array}$ & $\mathrm{CV}$ & $\begin{array}{l}\text { 107-base } \\
\text { miRNA }\end{array}$ & Yes & - & $30 \mathrm{~min}$ & - & $2.1 \cdot 10^{-8}$ & 2021 & [83] \\
\hline
\end{tabular}




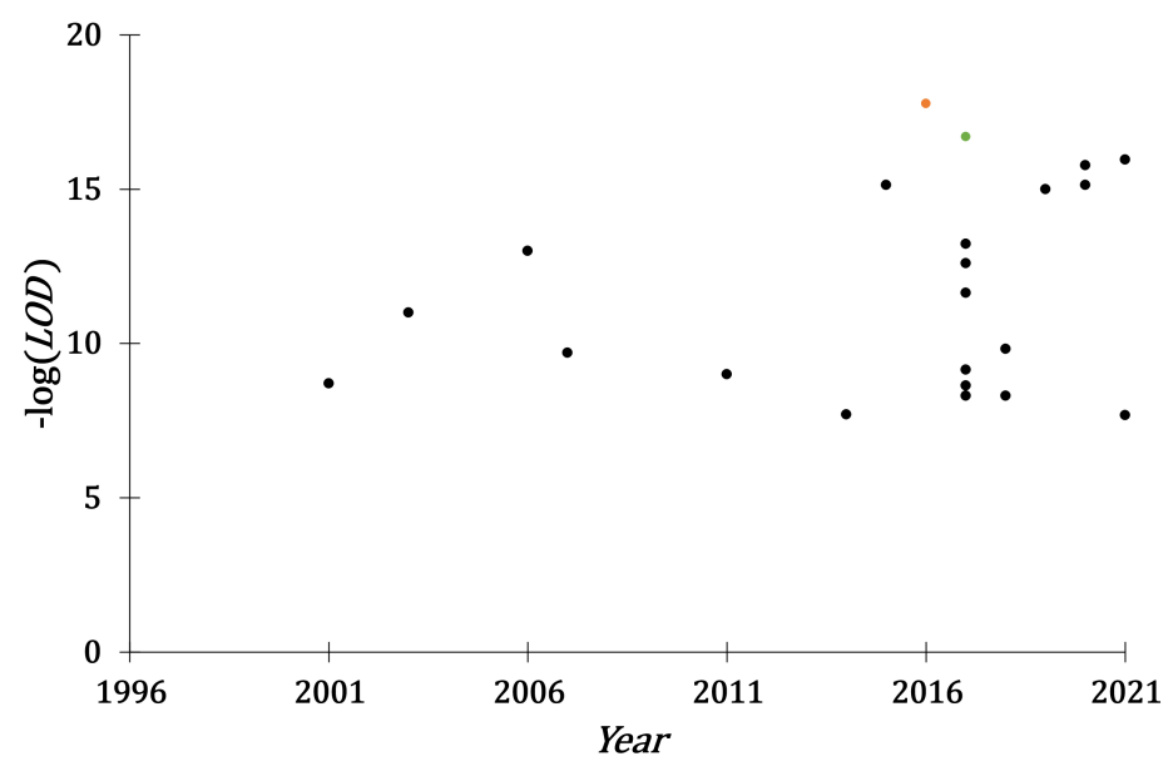

Fig. 9. $L O D$ evolution of electrochemical DNA-biosensors based on redox probe labeling. Green: attomolar LOD. Orange: attomolar LOD but sample volume not mentioned.

Six studies reported a LOD in the femtomolar range, two studies a LOD in the attomolar range and the lower reported LOD is equal to $1.7 \cdot 10^{-18} \mathrm{~mol} / \mathrm{L}$.

\section{Biosensors based on long-range electron transfer}

Long range electron transfer is the principle according to which most electrochemical biosensors are developed. The transduction in these sensors is explained by the increase of the electronic conductivity of the DNA duplex due to the stacking of the DNA bases along the helix axis. First generation biosensors are based on the electrochemical response of cationic redox species, such as tris(1,10-phenanthroline) cobalt (III) perchlorate (i.e. $[\mathrm{Co}(\mathrm{Phen})]^{3+}, 3 \mathrm{ClO}_{4}{ }^{-}$) intercalated in the negatively charged DNA-probes (Fig. 10).

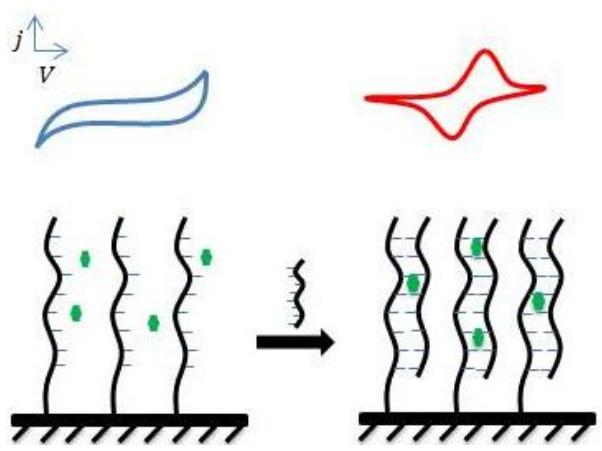

Fig. 10. Hybridization detection based on long-range electron transfer of cationic redox species: cyclic voltammetry response. 
In

Table 4 are summarized the LOD reported by the long-range electron transfer transduction

The LOD evolution over the years of this type of electrochemical DNA-biosensors is presented on Fig. 811.

Table 4. Detection limit of electrochemical DNA-biosensors based on long-range electron transfer.

\begin{tabular}{|c|c|c|c|c|c|c|c|c|c|}
\hline Electrode (setup) & \begin{tabular}{|c|}
$\begin{array}{c}\text { Electrochemical } \\
\text { detection }\end{array}$ \\
\end{tabular} & Target & PCR & $\begin{array}{l}\text { Target } \\
\text { Volume }\end{array}$ & $\begin{array}{c}\text { Hybridization } \\
\text { time }\end{array}$ & \begin{tabular}{|c|} 
Mismatch \\
detection
\end{tabular} & $\begin{array}{l}\text { LOD } \\
(\mathbf{M})\end{array}$ & Year & Ref. \\
\hline CPE (3-electrode) & DPV & $\begin{array}{l}\text { 20-base } \\
\text { DNA }\end{array}$ & No & - & $5 \min$ & - & $9.0 \cdot 10^{-9}$ & 2010 & {$[84]$} \\
\hline $\begin{array}{c}\mathrm{GC} / \mathrm{ZnONW} / \mathrm{MWCNT} / \mathrm{AuNP} \\
\text { (3-electrode) }\end{array}$ & DPV & $\begin{array}{l}\text { 24-base } \\
\text { DNA }\end{array}$ & No & $4 \mu \mathrm{L}$ & $35 \min$ & 1,3-base & $3.5 \cdot 10^{-14}$ & 2010 & {$[85]$} \\
\hline GC/graphene/ PANIw & DPV & $\begin{array}{l}\text { 24-base } \\
\text { DNA }\end{array}$ & No & - & $30 \mathrm{~min}$ & 3-base & $3.3 \cdot 10^{-13}$ & 2011 & {$[86]$} \\
\hline GC/MP/AuNPs (3-electrode) & DPV & $\begin{array}{l}\text { 22-base } \\
\text { DNA }\end{array}$ & No & - & $60 \mathrm{~min}$ & 4-base & $7.2 \cdot 10^{-11}$ & 2011 & {$[87]$} \\
\hline Au (3-electrode) & DPV & $\begin{array}{l}\text { 20-base } \\
\text { DNA }\end{array}$ & No & - & $40 \mathrm{~min}$ & 1-base & $1.0 \cdot 10^{-10}$ & 2012 & {$[88]$} \\
\hline GC/GO (3-electrode) & DPV & $\begin{array}{l}\text { 18-base } \\
\text { DNA }\end{array}$ & No & $10 \mu \mathrm{L}$ & $30 \mathrm{~min}$ & 2-base & $3.2 \cdot 10^{-14}$ & 2012 & {$[89]$} \\
\hline Gold/Ni(en) ${ }_{3} \mathrm{Ag}_{2} \mathrm{I}_{4}$ (3-electrode) & SWV & $\begin{array}{l}\text { 18-base } \\
\text { DNA }\end{array}$ & No & - & $240 \min$ & 1-base & $5.0 \cdot 10^{-12}$ & 2013 & {$[90]$} \\
\hline $\begin{array}{c}\text { GC/Fe@ AuNPs/AETGO } \\
\text { (3-electrode) }\end{array}$ & SWV & $\begin{array}{l}\text { 17-base } \\
\text { DNA }\end{array}$ & No & - & $20 \min$ & 1,2,3-base & $2.1 \cdot 10^{-15}$ & 2014 & {$[91]$} \\
\hline GC/ MWCNT-PAMAM & DPV & $\begin{array}{l}\text { 22-base } \\
\text { miRNA }\end{array}$ & No & $100 \mu \mathrm{L}$ & $60 \mathrm{~min}$ & 1-base & $5.0 \cdot 10^{-16}$ & 2015 & {$[92]$} \\
\hline $\mathrm{Au} / \mathrm{CS}-\mathrm{MWCNTs} / \mathrm{AuNPs}$ & DPV & $\begin{array}{l}\text { 21-base } \\
\text { DNA }\end{array}$ & Yes & $4 \mu \mathrm{L}$ & $30 \mathrm{~min}$ & 1,3-base & $3.3 \cdot 10^{-16}$ & 2015 & {$[93]$} \\
\hline Au (3-electrode) & DPV & $\begin{array}{l}\text { 18-base } \\
\text { DNA }\end{array}$ & No & $2.5 \mu \mathrm{L}$ & $120 \mathrm{~min}$ & 1-base & $1.7 \cdot 10^{-10}$ & 2016 & {$[94]$} \\
\hline ITO/AuNPs (3-electrode) & SWV & $\begin{array}{l}\text { 22-base } \\
\text { miRNA }\end{array}$ & No & - & $60 \mathrm{~min}$ & 1,2-base & $1.0 \cdot 10^{-15}$ & 2016 & {$[95]$} \\
\hline GC/IL/NrGO (3-electrode) & DPV & $\begin{array}{l}\text { 30-base } \\
\text { DNA }\end{array}$ & No & $5 \mu \mathrm{L}$ & $15 \min$ & 1,2-base & $8.1 \cdot 10^{-9}$ & 2017 & {$[96]$} \\
\hline Au (3-electrode) & DPV & $\begin{array}{l}\text { 24-base } \\
\text { miRNA }\end{array}$ & No & $100 \mu \mathrm{L}$ & $60 \mathrm{~min}$ & 1,4-base & $1.0 \cdot 10^{-7}$ & 2017 & {$[97]$} \\
\hline Au (3-electrode) & DPV & $\begin{array}{l}\text { 24-base } \\
\text { DNA }\end{array}$ & No & $40 \mu \mathrm{L}$ & $30 \mathrm{~min}$ & - & $1.2 \cdot 10^{-14}$ & 2017 & {$[98]$} \\
\hline GC/Pd-Au@CDs (3-electrode) & DPV & $\begin{array}{l}\text { 24-base } \\
\text { DNA }\end{array}$ & No & $200 \mu \mathrm{L}$ & $35 \min$ & 1,3-base & $1.9 \cdot 10^{-17}$ & 2017 & {$[99]$} \\
\hline Au-SPE (3-electrode) & DPV & $\begin{array}{l}\text { 21-base } \\
\text { DNA }\end{array}$ & No & $2.5 \mu \mathrm{L}$ & $120 \mathrm{~min}$ & 1,3-base & $8.5 \cdot 10^{-12}$ & 2017 & {$[100]$} \\
\hline GC/PEG/PANI (3-electrode) & DPV & $\begin{array}{l}\text { 19-base } \\
\text { DNA }\end{array}$ & No & $1 \mathrm{~mL}$ & $30 \mathrm{~min}$ & 1,3-base & $3.8 \cdot 10^{-15}$ & 2017 & [101] \\
\hline $\begin{array}{c}\text { CILE/AuNPs/RGO } \\
\text { (3-electrode) }\end{array}$ & DPV & $\begin{array}{l}\text { 22-base } \\
\text { DNA }\end{array}$ & Yes & $10 \mu \mathrm{L}$ & $30 \mathrm{~min}$ & 1,3-base & $3.2 \cdot 10^{-14}$ & 2017 & {$[102]$} \\
\hline Gr-PE /Ppy (3-electrode) & DPV & $\begin{array}{l}\text { 22-base } \\
\text { miRNA }\end{array}$ & No & $100 \mu \mathrm{L}$ & $30 \mathrm{~min}$ & 1-base & $1.7 \cdot 10^{-10}$ & 2017 & {$[103]$} \\
\hline $\begin{array}{c}\text { C-SP /GO/AuNWs } \\
\text { (3-electrode) }\end{array}$ & DPV & $\begin{array}{l}\text { 23-base } \\
\text { miRNA }\end{array}$ & No & $2.5 \mu \mathrm{L}$ & $120 \mathrm{~min}$ & 1,3-base & $1.7 \cdot 10^{-15}$ & 2017 & {$[104]$} \\
\hline $\mathrm{Au}$ (3-electrode) & DPV & 26-base & No & - & $30 \mathrm{~min}$ & - & $1.0 \cdot 10^{-9}$ & 2017 & [105] \\
\hline
\end{tabular}




\begin{tabular}{|c|c|c|c|c|c|c|c|c|c|}
\hline & & DNA & & & & & & & \\
\hline $\begin{array}{l}\text { C-SP /AuNPs/AcMPs } \\
\text { (3-electrode) }\end{array}$ & DPV & $\begin{array}{l}\text { 24-base } \\
\text { DNA }\end{array}$ & Yes & $300 \mu \mathrm{L}$ & $60 \mathrm{~min}$ & - & $1.0 \cdot 10^{-18}$ & 2017 & [106] \\
\hline $\begin{array}{l}\text { C-SP /AuNPs/PSA } \\
\text { (3-electrode) }\end{array}$ & DPV & $\begin{array}{l}\text { 30-base } \\
\text { DNA }\end{array}$ & No & - & $60 \mathrm{~min}$ & 3-base & $1.0 \cdot 10^{-21}$ & 2017 & [107] \\
\hline $\begin{array}{l}\text { KC-PPy-SPE/AuNPs } \\
\text { (3-electrode) }\end{array}$ & DPV & $\begin{array}{l}\text { 26-base } \\
\text { DNA }\end{array}$ & Yes & $350 \mu \mathrm{L}$ & $30 \min$ & 3,6,17-base & $5.0 \cdot 10^{-18}$ & 2017 & [108] \\
\hline FTO/Pt-Pd/ZnO (3-electrode) & $\mathrm{CV}$ & $\begin{array}{l}\text { 34-base } \\
\text { DNA }\end{array}$ & No & - & $120 \mathrm{~min}$ & - & $4.3 \cdot 10^{-5}$ & 2017 & [109] \\
\hline $\mathrm{GC} / 3 \mathrm{D} \mathrm{NG}-\mathrm{Fe}_{3} \mathrm{O}_{4}$ (3-electrode) & DPV & $\begin{array}{l}\text { 25-base } \\
\text { DNA }\end{array}$ & No & $5 \mu \mathrm{L}$ & $50 \mathrm{~min}$ & 1,3-base & $3.6 \cdot 10^{-15}$ & 2017 & [110] \\
\hline 3D-GF/AgNPs (3-electrode) & DPV & $\begin{array}{l}\text { 25-base } \\
\text { DNA }\end{array}$ & Yes & $5 \mu \mathrm{L}$ & $50 \mathrm{~min}$ & 1,3-base & $1.0 \cdot 10^{-14}$ & 2018 & [111] \\
\hline $\begin{array}{c}\text { Au-SPE/CDs/AuSPEs } \\
\text { (3-electrode) }\end{array}$ & DPV & $\begin{array}{l}\text { 25-base } \\
\text { DNA }\end{array}$ & Yes & $10 \mu \mathrm{L}$ & $60 \mathrm{~min}$ & 1-base & $1.6 \cdot 10^{-10}$ & 2018 & {$[112]$} \\
\hline AuNWEs (3-electrode) & SWV & $\begin{array}{l}\text { 22-base } \\
\text { DNA }\end{array}$ & No & $50 \mu \mathrm{L}$ & $120 \mathrm{~min}$ & 1,3-base & $4.8 \cdot 10^{-16}$ & 2018 & [113] \\
\hline GC/AuNPs (3-electrode) & DPV & $\begin{array}{l}\text { 22-base } \\
\text { miRNA }\end{array}$ & No & $200 \mu \mathrm{L}$ & $60 \mathrm{~min}$ & 1-base & $7.8 \cdot 10^{-17}$ & 2018 & {$[114]$} \\
\hline Pt (3-electrode) & DPV & $\begin{array}{l}\text { 33-base } \\
\text { DNA }\end{array}$ & No & $200 \mu \mathrm{L}$ & $60 \mathrm{~min}$ & - & $1.4 \cdot 10^{-18}$ & 2018 & [115] \\
\hline $\begin{array}{c}\text { C-SPE/Au colloid/Si } \\
\text { nanospheres (3-electrode) }\end{array}$ & DPV & $\begin{array}{l}\text { 30-base } \\
\text { DNA }\end{array}$ & No & $400 \mu \mathrm{L}$ & $90 \mathrm{~min}$ & 1-base & $1.0 \cdot 10^{-9}$ & 2018 & [116] \\
\hline $\begin{array}{l}\text { Pt/PEDOT:PSS/PEDOT/AuNPs } \\
\text { (3-electrode) }\end{array}$ & DPV & $\begin{array}{l}\text { 19-base } \\
\text { DNA }\end{array}$ & Yes & - & - & - & $1.0 \cdot 10^{-12}$ & 2018 & {$[117]$} \\
\hline Au/ns-AuNPs (3-electrode) & DPV & $\begin{array}{l}\text { 26-base } \\
\text { DNA }\end{array}$ & No & $10 \mu \mathrm{L}$ & $40 \mathrm{~min}$ & 1,2,3-base & $2.0 \cdot 10^{-19}$ & 2018 & [118] \\
\hline $\begin{array}{l}\text { C-SPE /AuNP/HSiSs } \\
\text { (3-electrode) }\end{array}$ & DPV & $\begin{array}{l}\text { 17-base } \\
\text { DNA }\end{array}$ & No & $300 \mu \mathrm{L}$ & $60 \mathrm{~min}$ & - & $8.2 \cdot 10^{-20}$ & 2018 & {$[119]$} \\
\hline $\begin{array}{c}\mathrm{GC} / \mathrm{H}_{2} \mathrm{~N}-\mathrm{GQD} / \mathrm{GA} \\
\text { (3-electrode) }\end{array}$ & DPV & $\begin{array}{l}\text { 22-base } \\
\text { miRNA }\end{array}$ & No & $5 \mu \mathrm{L}$ & $120 \mathrm{~min}$ & 1-base & $9.5 \cdot 10^{-11}$ & 2018 & [120] \\
\hline GC/PPy/PEG (3-electrode) & DPV & $\begin{array}{l}\text { 19-base } \\
\text { RNA }\end{array}$ & No & - & $60 \mathrm{~min}$ & 1,3-base & $3.3 \cdot 10^{-14}$ & 2019 & [121] \\
\hline GC (3-electrode) & DPV & $\begin{array}{l}\text { 24-base } \\
\text { DNA }\end{array}$ & No & $10 \mu \mathrm{L}$ & $60 \mathrm{~min}$ & 1,3-base & $1.0 \cdot 10^{-16}$ & 2019 & [122] \\
\hline $\mathrm{Au} /$ Chitosan (3-electrode) & DPV & $\begin{array}{l}\text { 22-base } \\
\text { miRNA }\end{array}$ & No & - & $120 \mathrm{~min}$ & 1-base & $8.0 \cdot 10^{-14}$ & 2019 & [123] \\
\hline Gr-PE (3-electrode) & DPV & $\begin{array}{l}\text { 22-base } \\
\text { miRNA }\end{array}$ & No & $100 \mu \mathrm{L}$ & $30 \mathrm{~min}$ & 2-base & $8.4 \cdot 10^{-8}$ & 2020 & {$[124]$} \\
\hline $\begin{array}{c}\text { C-SPE/rGO/PPy/AuNPs } \\
\text { (3-electrode) }\end{array}$ & DPV & $\begin{array}{l}\text { 22-base } \\
\text { DNA }\end{array}$ & No & $5 \mu \mathrm{L}$ & $15 \mathrm{~min}$ & 1,5-base & $4.0 \cdot 10^{-17}$ & 2020 & [125] \\
\hline GC/MWPPy/ZnO (3-electrode) & DPV & $\begin{array}{l}\text { 15-base } \\
\text { DNA }\end{array}$ & No & $20 \mu \mathrm{L}$ & $50 \mathrm{~min}$ & 1,2-base & $2.9 \cdot 10^{-11}$ & 2020 & [126] \\
\hline $\begin{array}{c}\text { C-SPE /rGO-MWCNT/AuNPs } \\
\text { (3-electrode) }\end{array}$ & DPV & $\begin{array}{l}\text { 14-base } \\
\text { DNA }\end{array}$ & Yes & - & $15 \mathrm{~min}$ & 1,3-base & $5.0 \cdot 10^{-17}$ & 2020 & {$[127]$} \\
\hline CILE/3D-Gr (3-electrode) & DPV & $\begin{array}{l}\text { 22-base } \\
\text { DNA }\end{array}$ & Yes & $10 \mu \mathrm{L}$ & $30 \mathrm{~min}$ & 1,3-base & $3.3 \cdot 10^{-13}$ & 2020 & {$[128]$} \\
\hline GC/P5Fin (3-electrode) & DPV & $\begin{array}{l}\text { 22-base } \\
\text { DNA }\end{array}$ & No & $10 \mu \mathrm{L}$ & $90 \min$ & - & $8.1 \cdot 10^{-13}$ & 2020 & [129] \\
\hline
\end{tabular}




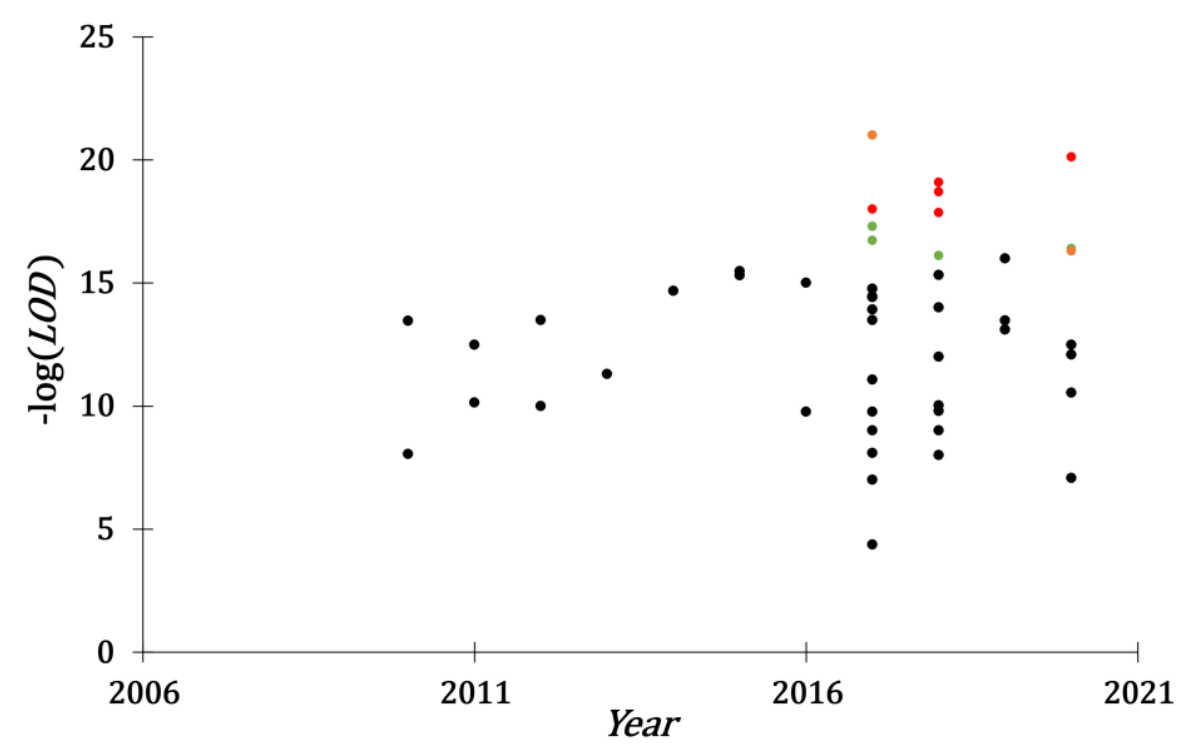

Fig. 11. $L O D$ evolution of electrochemical DNA-biosensors based on long-range electron transfer. Green: attomolar LOD. Orange: attomolar LOD but sample volume not mentioned. Red: attomolar detection but dilution of nucleic acid sample beyond Avogadro number.

Sixteen studies reported a LOD in the femtomolar range, ten studies a LOD in the attomolar range and the lower reported LOD is equal to $10^{-21} \mathrm{~mol} / \mathrm{L}$, unfortunately, the analytical sample volume was not mentioned for the two studies with the two lowest LODs and dilution of nucleic acid sample beyond Avogadro number for the four next LODs.

\section{Biosensors based on catalyzed long-range electron transfer}

Two redox systems are used to ensure the long-range electron transfer of electrochemical biosensors. They consist of a negatively charged redox mediator $\left(\left[\mathrm{Fe}(\mathrm{CN})_{6}\right]^{3-14-}\right)$ in solution at high concentration $\left(10^{-3} \mathrm{M}\right)$, and catalyst, which is an organic redox intercalator (methylene blue) adsorbed in the DNA biological layer at a low concentration $\left(10^{-6} \mathrm{M}\right)$.

The negatively charged DNA phosphate backbones block the diffusion of the redox mediator into the DNA layer due to electrostatic repulsions.

Furthermore, due to the very low concentration of the intercalator, the resulting current is very low. The redox signal of the indicator electro catalyzed by a long-range electron transfer enhanced by the redox intercalator represents the unique electrochemical response of this system ( Fig. 12). 


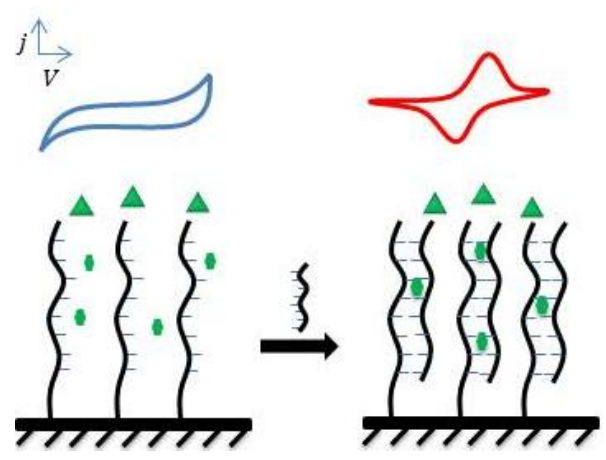

Fig. 12. Hybridization detection based on catalyzed long-range electron transfer (green triangles are redox indicators and green circles are redox intercalators.

Table 5 lists the references of works based on this transduction pathway allowing single mismatch detection and focused on detection of short DNA targets.

The results of the bibliography show that we can reach low detection limits, but we cannot evaluate the performance of these biosensors (Table 5 and Fig. 13).

As the faradic signal is not limited to the redox species adsorbed on the biosensor surface which explains the low detection limit. Another advantage of this transduction pathway, compared to all others, is the possible detection of a single mismatch at room temperature. Indeed, a single mismatched target can be hybridized without heating, but the mismatch induces a disruption of the axial stacking of the DNA bases, resulting in a decrease in the long-range electron transfer efficiency.

Table 5. Detection limit of electrochemical DNA-biosensors based on catalyzed long-range electron transfer.

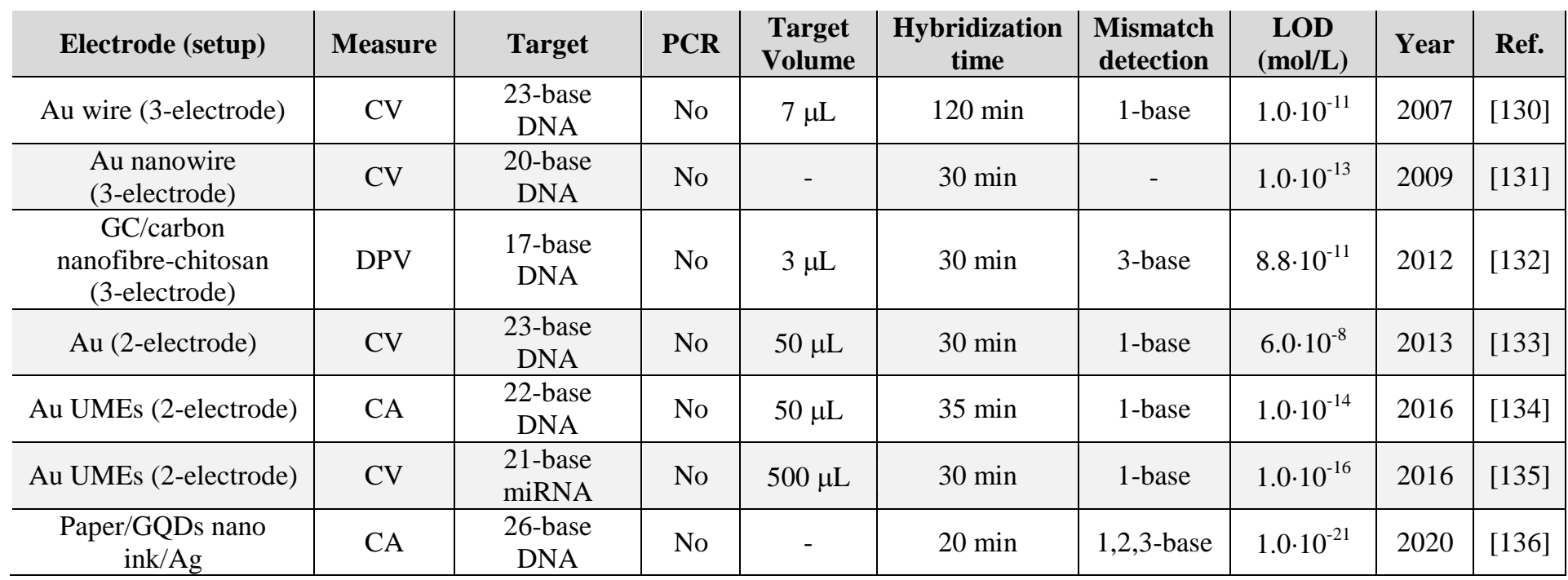




\begin{tabular}{|c|l|l|l|l|l|l|l|l|}
\hline $\begin{array}{c}\text { NPr/AuNPs-Cys } \\
(2-\text {-electrode })\end{array}$ & & & & & & & & \\
\hline
\end{tabular}

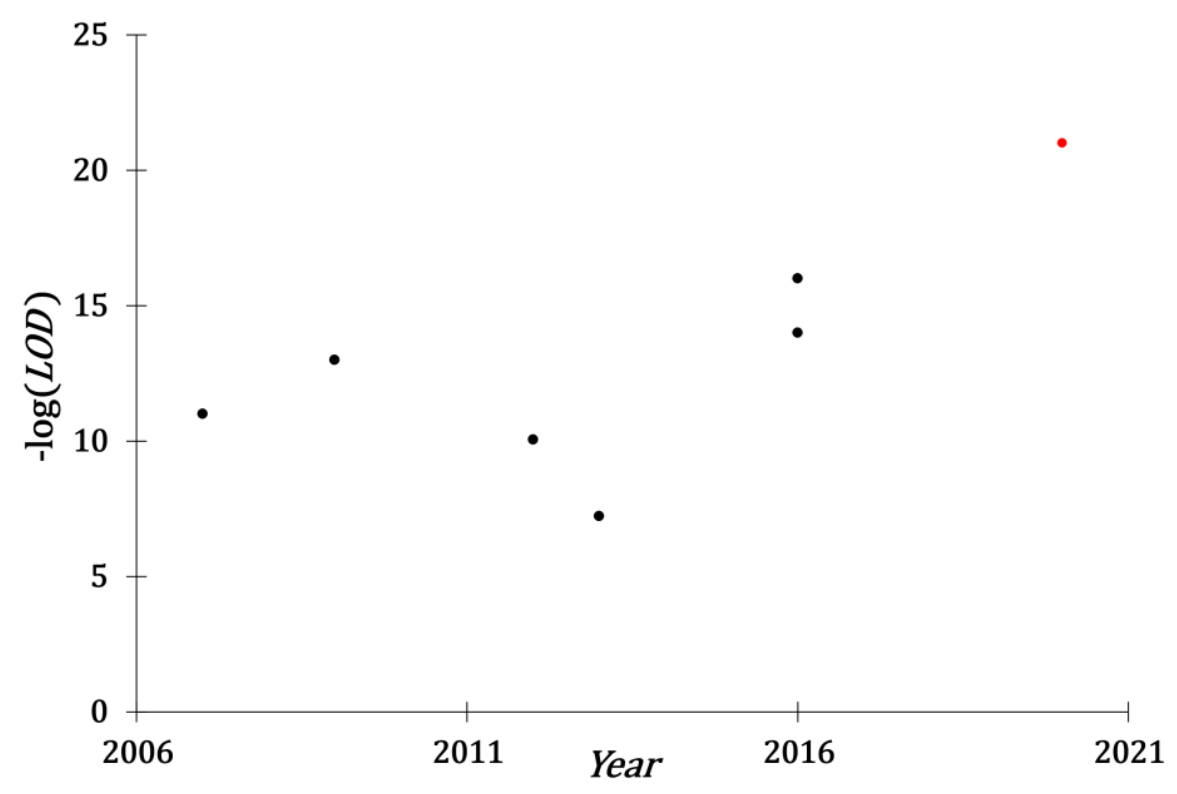

Fig. 13. $L O D$ evolution of electrochemical DNA-biosensors based on catalyzed long-range electron transfer. Red: attomolar detection limit but dilution of nucleic acid sample beyond Avogadro number.

Two studies reported a LOD in the femtomolar range, one study a LOD in the attomolar range and the lower reported LOD is equal to $10^{-21} \mathrm{~mol} / \mathrm{L}$, unfortunately, the dilution of nucleic acid sample is beyond Avogadro number.

\section{Biosensors Based on Conducting Polymers}

We can use the reversible oxidation of conjugated organic polymers, such as polypyrrole (PPy), to achieve transduction by hybridization (Fig. 14). The transduction is based on the modification of the electrochemical response of the conducting polymer following hybridization. 


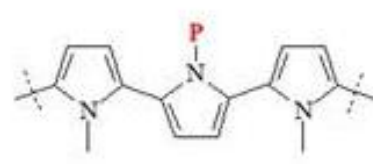

$+2 \mathrm{e}^{-} \mid-2 \mathrm{e}^{-}$

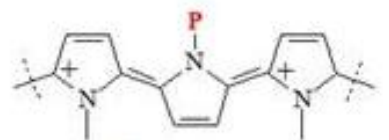

$\stackrel{j}{\mathrm{~V}}$

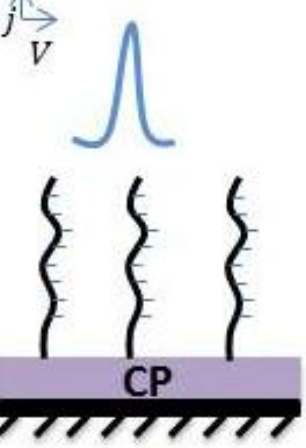

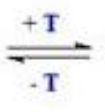

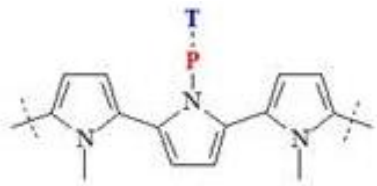

$+2 \mathrm{e}^{-} \|-2 \mathrm{e}^{-}$
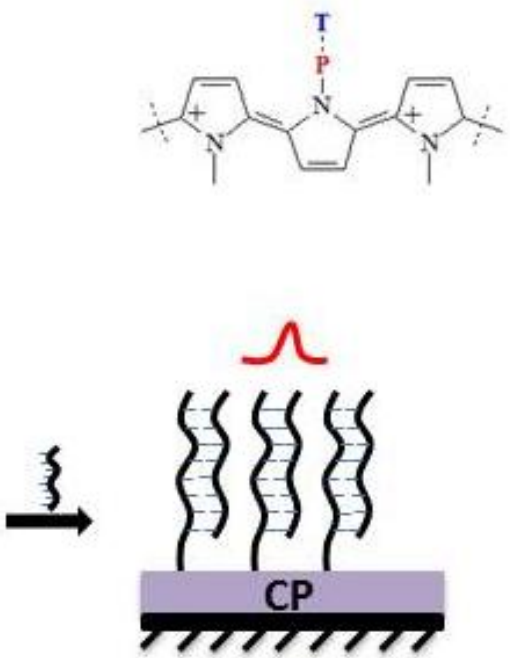

Fig. 12. Reversible pyrrole oxidation of polypyrrole response of probe $(\mathrm{P})$ and probe-target (P-T): Linear Sweep Voltammetry (LSV) response before (blue) and after (red) hybridization.

It is to be noted that guanine is preserved from oxidation because oxidation of conducting polymers such as polypyrrole to a dication group occurs at a low potential. This transduction pathway allows detection of single mismatches and is focused on detection of short DNA targets.

Despite the low detection limits (on the order of $10^{-15} \mathrm{M}$ ), this approach suffers from some limitations including the aging of the conducting polymer which can be irreversibly oxidized in air. Also, the discrimination of ss-DNA versus ds-DNA is poor because the difference in charge of the conductive polymer, before and after hybridization, is very small compared to the signal of the conductive polymer background (before hybridization).

The reported LODs for this transduction pathway are summarized in Table 6 and presented on Fig. 8. 
Table 6. Detection limit of electrochemical DNA-biosensors based on conducting polymers.

\begin{tabular}{|c|c|c|c|c|c|c|c|c|c|}
\hline $\begin{array}{c}\text { Electrode } \\
\text { (setup) }\end{array}$ & $\begin{array}{c}\text { Electrochemical } \\
\text { detection }\end{array}$ & Target & PCR & $\begin{array}{l}\text { Target } \\
\text { Volume }\end{array}$ & $\begin{array}{c}\text { Hybridization } \\
\text { time }\end{array}$ & $\begin{array}{c}\text { Mismatch } \\
\text { detection }\end{array}$ & $\begin{array}{c}\text { LOD } \\
(\mathrm{mol} / \mathrm{L})\end{array}$ & Year & Ref. \\
\hline $\begin{array}{c}\mathrm{Pt} / \mathrm{PPy} \\
\text { (3-electrode) }\end{array}$ & $\mathrm{CV}$ & $\begin{array}{c}\text { 15-base } \\
\text { DNA }\end{array}$ & No & - & $120 \mathrm{~min}$ & - & $1.0 \cdot 10^{-11}$ & 2001 & [137] \\
\hline $\begin{array}{c}\text { Pt/PPy-Fc } \\
\text { (3-electrode) }\end{array}$ & $\mathrm{CV}$ & $\begin{array}{c}\text { 25-base } \\
\text { DNA }\end{array}$ & No & - & $120 \mathrm{~min}$ & - & $1.0 \cdot 10^{-14}$ & 2002 & [138] \\
\hline $\begin{array}{c}\text { Pt/PTAE } \\
\text { (3-electrode) }\end{array}$ & $\mathrm{CV}$ & $\begin{array}{l}\text { 15-base } \\
\text { DNA }\end{array}$ & No & - & $180 \mathrm{~min}$ & 1-base & $1.0 \cdot 10^{-9}$ & 2003 & [139] \\
\hline $\begin{array}{c}\mathrm{Pt} / \mathrm{Ppy} \\
\text { (3-electrode) }\end{array}$ & $\mathrm{CA}$ & $\begin{array}{c}\text { 23-base } \\
\text { DNA }\end{array}$ & Yes & $50 \mu \mathrm{L}$ & $35 \mathrm{~min}$ & - & $5.2 \cdot 10^{-11}$ & 2004 & [140] \\
\hline $\begin{array}{c}\text { ITO/PPy } \\
\text { (3-electrode) }\end{array}$ & $\mathrm{CA}$ & $\begin{array}{c}\text { 41-base } \\
\text { DNA }\end{array}$ & No & $5 \mu \mathrm{L}$ & $30 \mathrm{~min}$ & - & $1.6 \cdot 10^{-15}$ & 2005 & [141] \\
\hline $\begin{array}{c}\mathrm{Au} / \mathrm{PPy} \\
\text { (3-electrode) }\end{array}$ & CA & $\begin{array}{l}\text { 20-base } \\
\text { DNA }\end{array}$ & No & - & $60 \mathrm{~min}$ & - & $7.2 \cdot 10^{-13}$ & 2006 & [142] \\
\hline $\begin{array}{c}\mathrm{Au} / \mathrm{PPy} \\
\text { (3-electrode) }\end{array}$ & $\mathrm{CV}$ & $\begin{array}{l}\text { 18-base } \\
\text { DNA }\end{array}$ & No & $10 \mu \mathrm{L}$ & $10 \mathrm{~min}$ & - & $1.6 \cdot 10^{-16}$ & 2006 & [143] \\
\hline $\begin{array}{l}\text { GC/poly(JU } \\
\text { G-co-JUGA) } \\
\text { (3-electrode) }\end{array}$ & SWV & $\begin{array}{c}10 \text { to } \\
\text { 30-bases } \\
\text { DNA }\end{array}$ & No & - & $120 \mathrm{~min}$ & 1,2-base & $2.5 \cdot 10^{-8}$ & 2006 & [144] \\
\hline $\begin{array}{c}\text { Gr-SPE/Ppy- } \\
\text { Fc } \\
\text { (3-electrode) }\end{array}$ & $\mathrm{CV}$ & $\begin{array}{l}\text { 33-base } \\
\text { DNA }\end{array}$ & No & $33 \mu \mathrm{L}$ & $60 \mathrm{~min}$ & - & $1.0 \cdot 10^{-10}$ & 2007 & [145] \\
\hline $\begin{array}{l}\text { GC/Ppy-co- } \\
\text { PPA } \\
\text { (3-electrode) }\end{array}$ & $\mathrm{CV}$ & $\begin{array}{l}\text { 18-bases } \\
\text { DNA }\end{array}$ & No & $40 \mu \mathrm{L}$ & $60 \mathrm{~min}$ & 1,2-base & $9.8 \cdot 10^{-10}$ & 2007 & [146] \\
\hline $\begin{array}{c}\mathrm{Au} / \mathrm{PPy} \\
\text { (3-electrode) }\end{array}$ & $\mathrm{CV}$ & $\begin{array}{c}\text { 24-base } \\
\text { DNA }\end{array}$ & No & - & - & - & $1.0 \cdot 10^{-12}$ & 2008 & [147] \\
\hline $\begin{array}{l}\text { GC/poly(JU } \\
\text { G-co-JUGA) } \\
\text { (3-electrode) }\end{array}$ & SWV & $\begin{array}{l}\text { 15-bases } \\
\text { DNA }\end{array}$ & No & $1 \mathrm{~mL}$ & $180 \mathrm{~min}$ & 1-base & $1.0 \cdot 10^{-8}$ & 2008 & [148] \\
\hline $\begin{array}{c}\mathrm{Au} / \mathrm{JUG}_{\text {thio }} \\
\text { (3-electrode) }\end{array}$ & SWV & $\begin{array}{l}\text { 20-bases } \\
\text { DNA }\end{array}$ & No & $50 \mu \mathrm{L}$ & $120 \mathrm{~min}$ & 1-base & $3.0 \cdot 10^{-10}$ & 2008 & [149] \\
\hline $\begin{array}{c}\text { GC/Pin } \\
\text { (3-electrode) }\end{array}$ & $\mathrm{CV}$ & $\begin{array}{l}\text { 18-bases } \\
\text { DNA }\end{array}$ & No & $3 \mathrm{~mL}$ & $60 \mathrm{~min}$ & 1-base & $5.8 \cdot 10^{-12}$ & 2009 & [150] \\
\hline $\begin{array}{c}\text { Au/Ppy-Fc } \\
\text { (3-electrode) }\end{array}$ & $\mathrm{CV}$ & $\begin{array}{l}\text { 32-base } \\
\text { DNA }\end{array}$ & No & $50 \mu \mathrm{L}$ & $120 \mathrm{~min}$ & - & $5.0 \cdot 10^{-17}$ & 2010 & [151] \\
\hline $\begin{array}{l}\text { GC/poly(JU } \\
\text { G-co-JUGA) } \\
\text { (3-electrode) }\end{array}$ & SWV & $\begin{array}{l}\text { 22-base } \\
\text { miRNA }\end{array}$ & No & $500 \mu \mathrm{L}$ & $120 \mathrm{~min}$ & - & $6.5 \cdot 10^{-13}$ & 2014 & [152] \\
\hline $\begin{array}{c}\mathrm{Pt} / \mathrm{PPy} \\
\text { (3-electrode) }\end{array}$ & DPV & $\begin{array}{c}\text { 40-base } \\
\text { DNA }\end{array}$ & No & - & $20 \mathrm{~min}$ & - & $1.0 \cdot 10^{-10}$ & 2014 & [153] \\
\hline $\begin{array}{c}\text { Au/MWCN } \\
\text { Ts/Ppy/PAM } \\
\text { AM-Fc } \\
\text { (3-electrode) } \\
\end{array}$ & $\mathrm{CV} / \mathrm{SWV}$ & $\begin{array}{l}\text { 15-base } \\
\text { DNA }\end{array}$ & Yes & - & $60 \mathrm{~min}$ & - & $3.0 \cdot 10^{-16}$ & 2015 & [154] \\
\hline $\begin{array}{l}\text { Au/PEDOT } \\
\text { (3-electrode) }\end{array}$ & DPV & $\begin{array}{c}\text { 21-base } \\
\text { DNA }\end{array}$ & No & - & $30 \mathrm{~min}$ & - & $1.3 \cdot 10^{-10}$ & 2015 & [155] \\
\hline $\begin{array}{c}\text { GC/AuNPs/J } \\
\text { UG-MHA } \\
\text { (3-electrode) }\end{array}$ & SWV & $\begin{array}{l}\text { 23-base } \\
\text { miRNA }\end{array}$ & No & $500 \mu \mathrm{L}$ & $60 \mathrm{~min}$ & - & $1.0 \cdot 10^{-13}$ & 2017 & [156] \\
\hline $\begin{array}{c}\text { GC/PANI/P } \\
\text { A } \\
\text { (3-electrode) }\end{array}$ & DPV, CV & $\begin{array}{l}\text { 22-base } \\
\text { miRNA }\end{array}$ & No & - & $45 \mathrm{~min}$ & 1,3-base & $3.4 \cdot 10^{-16}$ & 2020 & [157] \\
\hline
\end{tabular}




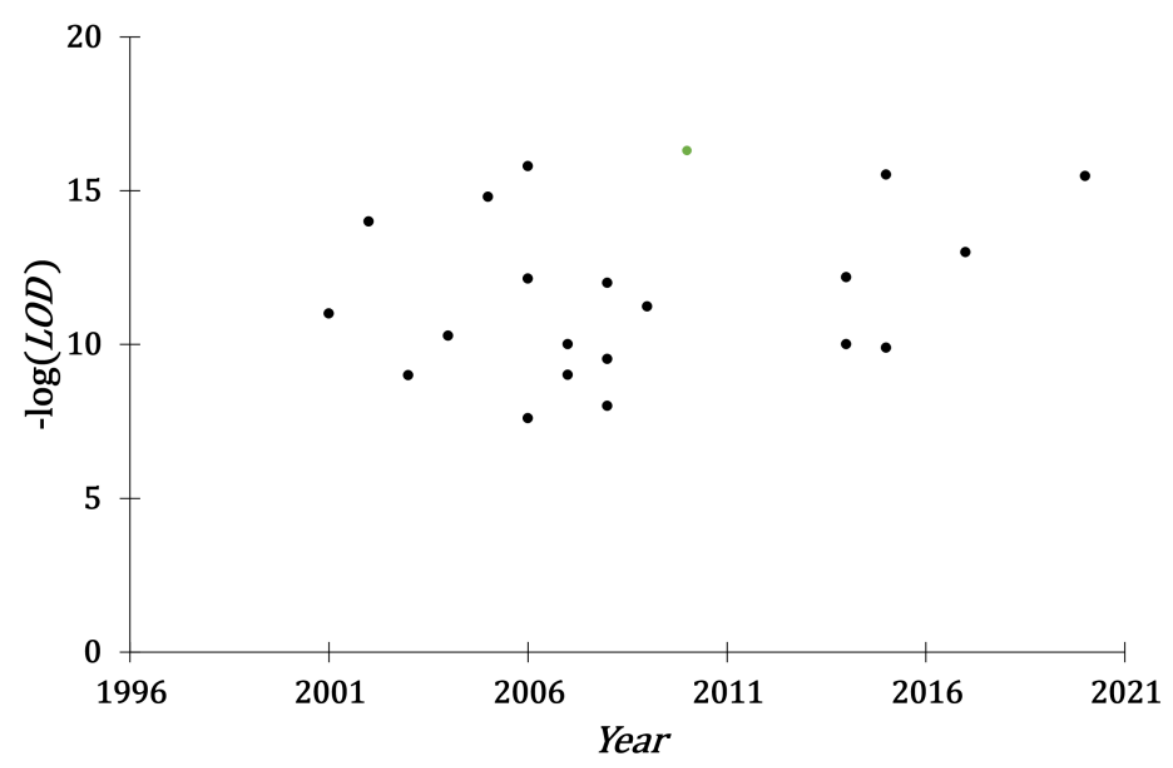

Fig. 13. $L O D$ evolution of electrochemical DNA-biosensors based on conducting polymers. Green: attomolar LOD.

Six studies reported a LOD in the femtomolar range and the lower reported LOD is equal to $5.0 \cdot 10^{-17} \mathrm{~mol} / \mathrm{L}$.

\section{Biosensors based on variation of resistance increase}

This transduction pathway is based on the decrease of the faradic charge after hybridization (Fig. ). It allows the detection of single mismatches and is focused on the detection of short DNA targets. The reported data show that low reproducible detection limits in the pM-fM range $\left(10^{-12} / 10^{-15} \mathrm{~mol} / \mathrm{L}\right)$ can be achieved (Table 7 and Fig. 8), but this transduction pathway is not attractive compared to long-range electron transfer because the hybridization response is lower than the initial response. Similarly, detection of a single mismatch is not possible at room temperature for the same reason, as both perfected matched and single mismatch DNA induce a decrease of the redox response. 


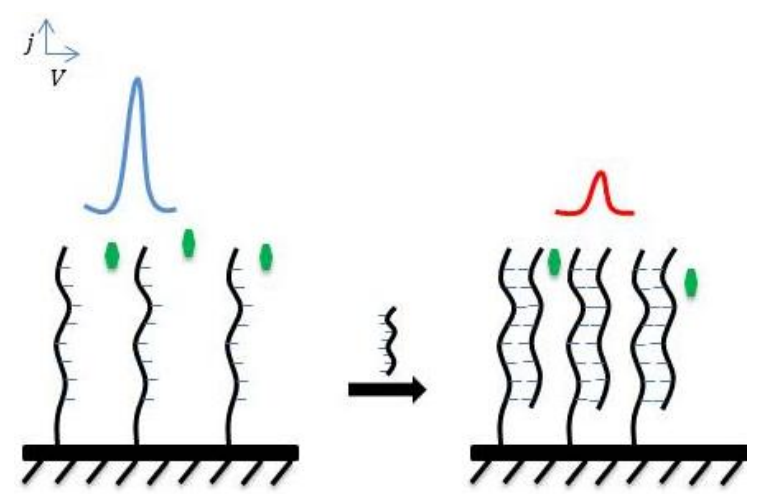

Fig. 14. Illustration of DNA biosensor variation of faradic resistance: (LSV) response.

Table 7. Detection limit of electrochemical DNA-biosensors based on faradaic resistance increase.

\begin{tabular}{|c|c|c|c|c|c|c|c|c|c|}
\hline $\begin{array}{l}\text { Electrode } \\
\text { (setup) }\end{array}$ & $\begin{array}{c}\text { Electrochemical } \\
\text { detection }\end{array}$ & Target & PCR & $\begin{array}{l}\text { Target } \\
\text { Volume }\end{array}$ & $\begin{array}{c}\text { Hybridization } \\
\text { time }\end{array}$ & $\begin{array}{l}\text { Mismatch } \\
\text { detection }\end{array}$ & $\begin{array}{c}\text { LOD } \\
(\mathrm{mol} / \mathrm{L})\end{array}$ & Year & Ref. \\
\hline Au (3-electrode) & DPV & $\begin{array}{c}\text { 24-base } \\
\text { DNA }\end{array}$ & No & No & $30 \min$ & 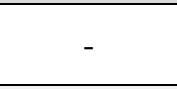 & $1.0 \cdot 10^{-10}$ & 2004 & [158] \\
\hline $\begin{array}{c}\mathrm{GC} / \mathrm{CeO}_{2} / \mathrm{CHIT} \\
\text { (3-electrode) }\end{array}$ & DPV & $\begin{array}{c}\text { 44-base } \\
\text { DNA }\end{array}$ & No & $10 \mu \mathrm{L}$ & $60 \mathrm{~min}$ & 4-base & $1.6 \cdot 10^{-11}$ & 2006 & [159] \\
\hline $\begin{array}{l}\text { GC/PDC/SWN } \\
\text { Ts (3-electrode) }\end{array}$ & EIS & $\begin{array}{c}\text { 20-base } \\
\text { DNA }\end{array}$ & Yes & $10 \mu \mathrm{L}$ & $500 \mathrm{~s}$ & 1,2-base & $1.4 \cdot 10^{-12}$ & 2007 & [160] \\
\hline $\begin{array}{c}\text { GC/PDC-SWN } \\
\text { Ts/PDDA } \\
\text { (3-electrode) }\end{array}$ & DPV & $\begin{array}{c}\text { 20-base } \\
\text { DNA }\end{array}$ & Yes & $2 \mathrm{~mL}$ & $60 \mathrm{~min}$ & 1,2-base & $2.6 \cdot 10^{-12}$ & 2008 & [161] \\
\hline $\begin{array}{l}\text { GC/EBT/NG } \\
\text { (3-electrode) }\end{array}$ & DPV & $\begin{array}{c}\text { 18-base } \\
\text { DNA }\end{array}$ & No & $10 \mu \mathrm{L}$ & $60 \mathrm{~min}$ & 1-base & $1.0 \cdot 10^{-13}$ & 2010 & [162] \\
\hline $\begin{array}{l}\text { Au/GG1PAMA } \\
\text { M (3-electrode) }\end{array}$ & DPV & $\begin{array}{c}\text { 23-base } \\
\text { DNA }\end{array}$ & No & $5 \mu \mathrm{L}$ & - & 1-base & $1.0 \cdot 10^{-12}$ & 2012 & [163] \\
\hline $\begin{array}{c}\mathrm{Au} / \mathrm{ZrO} 2-\mathrm{CeO} 2 / \\
\text { Chitosan } \\
\text { (3-electrode) }\end{array}$ & DPV & $\begin{array}{c}\text { 20-base } \\
\text { DNA }\end{array}$ & No & $10 \mu \mathrm{L}$ & $60 \mathrm{~min}$ & 3-base & $3.0 \cdot 10^{-14}$ & 2012 & [164] \\
\hline $\begin{array}{c}\text { GC/CuS-Gr/Au } \\
\text { NPs } \\
\text { (3-electrode) }\end{array}$ & DPV & $\begin{array}{c}\text { 18-base } \\
\text { DNA }\end{array}$ & No & $10 \mu \mathrm{L}$ & $50 \mathrm{~min}$ & 1,3-base & $1.0 \cdot 10^{-13}$ & 2014 & [165] \\
\hline $\begin{array}{c}\text { GC/MWCNT } \\
\text { (3-electrode) }\end{array}$ & DPV & $\begin{array}{c}\text { 22-base } \\
\text { DNA }\end{array}$ & No & $10 \mu \mathrm{L}$ & $60 \mathrm{~min}$ & 3-base & $1.0 \cdot 10^{-11}$ & 2016 & [166] \\
\hline $\begin{array}{c}\text { Au nanotubes } \\
\text { array } \\
\text { (3-electrode) }\end{array}$ & DPV & $\begin{array}{c}\text { 21-base } \\
\text { DNA }\end{array}$ & No & $10 \mu \mathrm{L}$ & $45 \min$ & - & $7.7 \cdot 10^{-9}$ & 2016 & [167] \\
\hline $\begin{array}{c}\text { GC/hemin-rGO/ } \\
\text { AuNPs } \\
\text { (3-electrode) }\end{array}$ & DPV & $\begin{array}{c}\text { 22-base } \\
\text { DNA }\end{array}$ & No & $50 \mu \mathrm{L}$ & $90 \min$ & 1,2,3-base & $1.4 \cdot 10^{-19}$ & 2017 & [168] \\
\hline $\begin{array}{c}\text { PEG/CB } \\
\text { (3-electrode) }\end{array}$ & EIS & $\begin{array}{l}\text { 24-base } \\
\text { miRNA }\end{array}$ & No & $100 \mu \mathrm{L}$ & $35 \mathrm{~min}$ & - & $1.0 \cdot 10^{-11}$ & 2017 & [169] \\
\hline Au (3-electrode) & $\mathrm{CV}$ & $\begin{array}{l}\text { 18-base } \\
\text { DNA }\end{array}$ & Yes & - & $60 \mathrm{~min}$ & - & $2.0 \cdot 10^{-16}$ & 2017 & [170] \\
\hline $\begin{array}{c}\text { C-SPE } \\
\text { /ZnO/PSE-G } \\
\text { (3-electrode) }\end{array}$ & EIS & $\begin{array}{c}\text { 25-base } \\
\text { RNA }\end{array}$ & No & $5 \mu \mathrm{L}$ & $60 \mathrm{~min}$ & 1,2-base & $4.3 \cdot 10^{-12}$ & 2017 & [171] \\
\hline Au (3-electrode) & DPV & $\begin{array}{c}\text { 18-base } \\
\text { DNA }\end{array}$ & No & - & $40 \min$ & 1,2,3-base & $7.6 \cdot 10^{-15}$ & 2017 & [172] \\
\hline $\mathrm{Au}$ (3-electrode) & EIS & 25-base & No & $30 \mu \mathrm{L}$ & $720 \mathrm{~min}$ & 2-base & $1.5 \cdot 10^{-10}$ & 2017 & [173] \\
\hline
\end{tabular}




\begin{tabular}{|c|c|c|c|c|c|c|c|c|c|}
\hline & & DNA & & & & & & & \\
\hline $\begin{array}{c}\mathrm{GC} / \mathrm{GO} \\
\text { (3-electrode) }\end{array}$ & DPV & $\begin{array}{l}\text { 16-base } \\
\text { DNA }\end{array}$ & No & $10 \mu \mathrm{L}$ & $60 \min$ & 1-base & $1.2 \cdot 10^{-9}$ & 2017 & [174] \\
\hline $\begin{array}{c}\text { GC/MoS } \mathrm{MoShi}_{2} \text { - } \\
\text { uNPs } \\
\text { (3-electrode) }\end{array}$ & SWV & $\begin{array}{l}\text { 22-base } \\
\text { miRNA }\end{array}$ & No & $5 \mu \mathrm{L}$ & $50 \mathrm{~min}$ & 1-base & $2.6 \cdot 10^{-13}$ & 2017 & [175] \\
\hline $\begin{array}{c}\text { GC/Cys-AuNPs } \\
\text { (3-electrode) }\end{array}$ & EIS & $\begin{array}{l}\text { 22-base } \\
\text { miRNA }\end{array}$ & No & $30 \mu \mathrm{L}$ & $120 \mathrm{~min}$ & 1-base & $2.5 \cdot 10^{-13}$ & 2017 & [176] \\
\hline $\begin{array}{c}\mathrm{Au} / \mathrm{Fc} / \mathrm{PAMAM} \\
\text { (3-electrode) }\end{array}$ & DPV & $\begin{array}{l}\text { 23-base } \\
\text { DNA }\end{array}$ & No & - & $60 \mathrm{~min}$ & 1-base & $3.0 \cdot 10^{-10}$ & 2019 & [177] \\
\hline $\begin{array}{l}\text { Gr-SPE/G/AuN } \\
\text { Ps (3-electrode) }\end{array}$ & DPV & $\begin{array}{l}\text { 15-base } \\
\text { DNA }\end{array}$ & No & $8 \mu \mathrm{L}$ & $5 \mathrm{~min}$ & 1-base & $3.6 \cdot 10^{-16}$ & 2017 & [178] \\
\hline $\begin{array}{c}\mathrm{GC} \\
\text { (3-electrode) } \\
\end{array}$ & EIS & $\begin{array}{c}\text { 25-base } \\
\text { DNA }\end{array}$ & No & $2 \mu \mathrm{L}$ & $120 \mathrm{~min}$ & 1-base & $1.5 \cdot 10^{-13}$ & 2017 & [179] \\
\hline Au (3-electrode) & EIS & $\begin{array}{c}\text { 38-base } \\
\text { DNA }\end{array}$ & No & $20 \mu \mathrm{L}$ & $120 \mathrm{~min}$ & - & $1.0 \cdot 10^{-7}$ & 2017 & [180] \\
\hline $\begin{array}{c}\text { GC/MNF } \\
\text { (3-electrode) }\end{array}$ & CV/EIS/DPV & $\begin{array}{l}\text { 28-base } \\
\text { DNA }\end{array}$ & No & - & $60 \mathrm{~min}$ & - & $1.2 \cdot 10^{-19}$ & 2017 & [181] \\
\hline $\begin{array}{c}\mathrm{GC} / \mathrm{GO} / \mathrm{CS} \\
\text { (3-electrode) }\end{array}$ & EIS & $\begin{array}{l}\text { 21-base } \\
\text { DNA }\end{array}$ & No & $15 \mu \mathrm{L}$ & $50 \min$ & 1,2-base & $3.6 \cdot 10^{-15}$ & 2017 & [182] \\
\hline $\begin{array}{l}\text { ITO/NVTO/CH } \\
\text { IT (3-electrode) }\end{array}$ & EIS & $\begin{array}{l}\text { 26-base } \\
\text { DNA }\end{array}$ & No & $10 \mu \mathrm{L}$ & $60 \mathrm{~min}$ & 1,2-base & $1.1 \cdot 10^{-16}$ & 2017 & [183] \\
\hline $\begin{array}{c}\text { Au-NTs/PC } \\
\text { (3-electrode) }\end{array}$ & EIS & $\begin{array}{l}\text { 25-base } \\
\text { DNA }\end{array}$ & No & $1 \mu \mathrm{L}$ & - & 1-base & $1.0 \cdot 10^{-15}$ & 2018 & [184] \\
\hline $\begin{array}{c}\text { Gr-SPE /AuNPs } \\
\text { (3-electrode) }\end{array}$ & EIS & $\begin{array}{l}\text { 14-base } \\
\text { DNA }\end{array}$ & No & $15 \mu \mathrm{L}$ & $60 \mathrm{~min}$ & - & $1.0 \cdot 10^{-7}$ & 2018 & [185] \\
\hline $\begin{array}{c}\mathrm{Au} / \mathrm{AgNF} / \mathrm{PPy} \\
\text { (3-electrode) }\end{array}$ & $\mathrm{CV}$ & $\begin{array}{l}\text { 22-base } \\
\text { miRNA }\end{array}$ & No & $10 \mu \mathrm{L}$ & $15 \min$ & 1,2-base & $2.0 \cdot 10^{-16}$ & 2018 & [186] \\
\hline Au (3-electrode) & $\mathrm{CV}$ & $\begin{array}{l}\text { 50-base } \\
\text { DNA }\end{array}$ & Yes & $20 \mu \mathrm{L}$ & $180 \min$ & - & $6.5 \cdot 10^{-13}$ & 2018 & [187] \\
\hline Au (3-electrode) & DPV & $\begin{array}{l}\text { 32-base } \\
\text { DNA }\end{array}$ & No & $40 \mu \mathrm{L}$ & - & - & $7.9 \cdot 10^{-12}$ & 2018 & [188] \\
\hline $\begin{array}{c}\text { GC/Thi-rGO/Au } \\
\text { NPs } \\
\text { (3-electrode) } \\
\end{array}$ & DPV & $\begin{array}{l}\text { 22-base } \\
\text { DNA }\end{array}$ & No & $5 \mu \mathrm{L}$ & $60 \mathrm{~min}$ & 1,2,3-base & $4.3 \cdot 10^{-19}$ & 2018 & [189] \\
\hline $\begin{array}{c}\text { Carbon } \\
\text { graphene } \\
\text { ink/PAD } \\
\text { (3-electrode) }\end{array}$ & EIS & $\begin{array}{l}\text { 15-base } \\
\text { DNA }\end{array}$ & Yes & $3 \mu \mathrm{L}$ & $15 \min$ & 1,2-base & $1.2 \cdot 10^{-9}$ & 2018 & [190] \\
\hline $\begin{array}{c}\mathrm{Au} / \mathrm{MNP}-\mathrm{CNTs} \\
\text { (3-electrode) }\end{array}$ & DPV & $\begin{array}{l}\text { 25-base } \\
\text { DNA }\end{array}$ & No & $40 \mu \mathrm{L}$ & $60 \mathrm{~min}$ & 1-base & $8.4 \cdot 10^{-12}$ & 2018 & [191] \\
\hline $\begin{array}{c}\text { Gr-SPE/MoS } \\
\text { (3-electrode) }\end{array}$ & CV, EIS & $\begin{array}{l}\text { 20-base } \\
\text { DNA }\end{array}$ & No & $3 \mu \mathrm{L}$ & $35 \mathrm{~s}$ & - & $3.4 \cdot 10^{-9}$ & 2018 & [192] \\
\hline $\begin{array}{c}\text { FTO/NFG/AgN } \\
\text { Ps/PANI } \\
\text { (3-electrode) } \\
\end{array}$ & DPV & $\begin{array}{l}\text { 22-base } \\
\text { miRNA }\end{array}$ & No & - & $30 \mathrm{~min}$ & - & $2.0 \cdot 10^{-16}$ & 2018 & [193] \\
\hline $\begin{array}{c}\text { GC/poly } \\
\text { (Py-co-PAA) } \\
\text { (3-electrode) } \\
\end{array}$ & EIS & $\begin{array}{l}\text { 25-base } \\
\text { DNA }\end{array}$ & No & $20 \mu \mathrm{L}$ & $60 \mathrm{~min}$ & - & $2.9 \cdot 10^{-9}$ & 2018 & [194] \\
\hline Au (3-electrode) & DPV & $\begin{array}{l}\text { 22-base } \\
\text { miRNA }\end{array}$ & No & $5 \mu \mathrm{L}$ & $20 \min$ & - & $1.0 \cdot 10^{-12}$ & 2018 & [195] \\
\hline $\begin{array}{c}\text { ITO-PET/P }{ }_{3} \text { AN } \\
\text { A/PU } \\
\text { (3-electrode) }\end{array}$ & EIS & DNA & No & - & $60 \min$ & 1,2-base & $1.0 \cdot 10^{-7}$ & 2018 & [196] \\
\hline $\begin{array}{c}\text { PEG/GO } \\
\text { (3-electrode) }\end{array}$ & EIS & $\begin{array}{l}\text { 22-base } \\
\text { miRNA }\end{array}$ & No & $100 \mu \mathrm{L}$ & $30 \mathrm{~min}$ & - & $2.6 \cdot 10^{-7}$ & 2018 & [197] \\
\hline $\begin{array}{c}\mathrm{GC} / \mathrm{GO} / \mathrm{AgNPs} \\
\text { (3-electrode) }\end{array}$ & EIS & $\begin{array}{l}\text { 23-base } \\
\text { miRNA }\end{array}$ & No & $10 \mathrm{~mL}$ & $30 \mathrm{~min}$ & 6-base & $4.5 \cdot 10^{-15}$ & 2018 & [198] \\
\hline GC/ERGO/PP 3 & EIS, DPV & 19-base & No & $20 \mu \mathrm{L}$ & $60 \mathrm{~min}$ & 2,3-base & $3.0 \cdot 10^{-15}$ & 2018 & [199] \\
\hline
\end{tabular}




\begin{tabular}{|c|c|c|c|c|c|c|c|c|c|}
\hline $\begin{array}{c}\mathrm{CA} \\
\text { (3-electrode) }\end{array}$ & & DNA & & & & & & & \\
\hline $\begin{array}{c}\mathrm{GC} / \mathrm{Gr} \\
\text { (3-electrode) }\end{array}$ & EIS & $\begin{array}{l}\text { 15-base } \\
\text { DNA }\end{array}$ & No & $100 \mu \mathrm{L}$ & $30 \mathrm{~min}$ & 1,3-base & $1.0 \cdot 10^{-18}$ & 2018 & [200] \\
\hline $\begin{array}{c}\mathrm{Au} / \mathrm{CeO}_{2} \mathrm{NRs} \\
\text { (3-electrode) }\end{array}$ & EIS & $\begin{array}{c}\text { 26-base } \\
\text { DNA }\end{array}$ & No & $30 \mu \mathrm{L}$ & $40 \mathrm{~min}$ & - & $1.0 \cdot 10^{-8}$ & 2018 & [201] \\
\hline $\begin{array}{c}\text { CPE/RCNFs - } \\
\text { MWCNTs } \\
\text { (3-electrode) }\end{array}$ & EIS & $\begin{array}{l}\text { 19-base } \\
\text { DNA }\end{array}$ & No & $10 \mu \mathrm{L}$ & $30 \mathrm{~min}$ & 2,3-base & $2.4 \cdot 10^{-12}$ & 2018 & [202] \\
\hline $\begin{array}{c}\mathrm{GC} / \mathrm{Gr} / \mathrm{Pol} / \mathrm{AuN} \\
\mathrm{P}(3 \text {-electrode) }\end{array}$ & DPV & $\begin{array}{c}\text { 18-base } \\
\text { DNA }\end{array}$ & No & $6 \mu \mathrm{L}$ & $120 \mathrm{~min}$ & 4-base & $1.0 \cdot 10^{-12}$ & 2018 & [203] \\
\hline $\begin{array}{c}\mathrm{Au} / \\
\text { AgNPs/CD/lipid } \\
\text { /MPA } \\
\text { (3-electrode) } \\
\end{array}$ & EIS & $\begin{array}{c}\text { 30-base } \\
\text { DNA }\end{array}$ & No & $2 \mu \mathrm{L}$ & $60 \mathrm{~min}$ & 1,2,3-base & $1.0 \cdot 10^{-16}$ & 2019 & [204] \\
\hline $\begin{array}{c}\text { ITO/c-GNF/AP } \\
\text { TMS-ZnO } \\
\text { (3-electrode) }\end{array}$ & EIS & $\begin{array}{c}\text { 17-base } \\
\text { DNA }\end{array}$ & No & $20 \mu \mathrm{L}$ & $30 \mathrm{~min}$ & 1-base & $1.0 \cdot 10^{-16}$ & 2019 & [205] \\
\hline $\begin{array}{c}\mathrm{FTO} / \mathrm{Gr} \\
\text { microfiber/ZnO } \\
\text { (3-electrode) }\end{array}$ & EIS & $\begin{array}{c}\text { 20-base } \\
\text { DNA }\end{array}$ & No & - & $2 \min$ & 1-base & $3.3 \cdot 10^{-15}$ & 2019 & [206] \\
\hline $\begin{array}{c}\text { GC/ERGO/PAB } \\
\text { A/AuNPs } \\
\text { (3-electrode) }\end{array}$ & EIS & $\begin{array}{c}\text { 20-base } \\
\text { DNA }\end{array}$ & No & $5 \mu \mathrm{L}$ & $60 \mathrm{~min}$ & 2,4-base & $3.7 \cdot 10^{-17}$ & 2019 & [207] \\
\hline $\begin{array}{c}\text { Ti/AuNPs } \\
\text { (3-electrode) }\end{array}$ & DPV & $\begin{array}{c}\text { 28-base } \\
\text { DNA }\end{array}$ & Yes & $20 \mu \mathrm{L}$ & $60 \mathrm{~min}$ & 2-base & $9.7 \cdot 10^{-16}$ & 2019 & [208] \\
\hline $\begin{array}{c}\mathrm{GC} / \mathrm{AGr} \\
\text { (3-electrode) }\end{array}$ & DPV & $\begin{array}{l}\text { 23-base } \\
\text { miRNA }\end{array}$ & No & $3 \mu \mathrm{L}$ & $180 \mathrm{~min}$ & 1-base & $1.3 \cdot 10^{-14}$ & 2019 & [209] \\
\hline $\begin{array}{c}\mathrm{GC} / \mathrm{GN} \\
\text { (3-electrode) }\end{array}$ & EIS & $\begin{array}{c}\text { 20-base } \\
\text { DNA }\end{array}$ & No & $5 \mu \mathrm{L}$ & $60 \mathrm{~min}$ & 1,2,3-base & $1.0 \cdot 10^{-16}$ & 2019 & [210] \\
\hline $\begin{array}{c}\mathrm{Si} / \mathrm{Pt} / \mathrm{ZnO} \\
\text { (3-electrode) }\end{array}$ & EIS & $\begin{array}{c}\text { 36-base } \\
\text { DNA }\end{array}$ & No & $10 \mu \mathrm{L}$ & - & - & $2.8 \cdot 10^{-13}$ & 2019 & [201] \\
\hline $\begin{array}{c}\mathrm{GC} / \mathrm{CHIT} / \mathrm{CeO}_{2} \\
\text { (3-electrode) }\end{array}$ & EIS/DPV & $\begin{array}{c}\text { 20-base } \\
\text { DNA }\end{array}$ & No & $5 \mu \mathrm{L}$ & $30 \min$ & 1, 3-base & $2.0 \cdot 10^{-15}$ & 2019 & [212] \\
\hline Au (3-electrode) & $\mathrm{CV}$ & $\begin{array}{c}\text { 17-base } \\
\text { DNA }\end{array}$ & No & $5 \mu \mathrm{L}$ & $10 \mathrm{~min}$ & 1,2,3-base & $1.0 \cdot 10^{-13}$ & 2019 & [213] \\
\hline $\begin{array}{c}\mathrm{C}-\mathrm{SPE} / \mathrm{G}_{2}-\mathrm{PS} \\
\text { (3-electrode) }\end{array}$ & EIS & $\begin{array}{l}\text { 22-base } \\
\text { miRNA }\end{array}$ & No & $35 \mu \mathrm{L}$ & $30 \mathrm{~min}$ & - & $1.4 \cdot 10^{-7}$ & 2019 & [214] \\
\hline $\begin{array}{l}\text { Paper/Graphehe } \\
\text { ink (3-electrode) }\end{array}$ & DPV & $\begin{array}{c}\text { 21-base } \\
\text { DNA }\end{array}$ & No & $2 \mu \mathrm{L}$ & $40 \mathrm{~min}$ & 1,2-base & $1.5 \cdot 10^{-12}$ & 2020 & [215] \\
\hline $\begin{array}{c}\mathrm{GC} / \mathrm{ZnO} / \mathrm{AuNPs} \\
\text { (3-electrode) }\end{array}$ & DPV & $\begin{array}{l}\text { 19-base } \\
\text { DNA }\end{array}$ & No & - & $45 \min$ & 2,3-base & $1.8 \cdot 10^{-12}$ & 2020 & [216] \\
\hline $\begin{array}{l}\text { GC/PA@Ni-M } \\
\text { OF (3-electrode) }\end{array}$ & EIS & $\begin{array}{c}\text { 27-base } \\
\text { DNA }\end{array}$ & No & $10 \mu \mathrm{L}$ & $60 \mathrm{~min}$ & - & $7.5 \cdot 10^{-16}$ & 2020 & [217] \\
\hline Au (3-electrode) & EIS & $\begin{array}{c}\text { 22-base } \\
\text { DNA }\end{array}$ & No & $200 \mu \mathrm{L}$ & $60 \mathrm{~min}$ & - & $4.1 \cdot 10^{-11}$ & 2020 & [218] \\
\hline $\begin{array}{c}\text { Paper/AuNPs } \\
\text { (3-electrode) }\end{array}$ & EIS & $\begin{array}{l}\text { 23-base } \\
\text { miRNA }\end{array}$ & No & $5 \mu \mathrm{L}$ & $5 \min$ & 1-base & $3.4 \cdot 10^{-8}$ & 2021 & [219] \\
\hline $\begin{array}{c}\mathrm{GCE} \\
\text { (3-electrode) }\end{array}$ & DPV & $\begin{array}{c}\text { 20-base } \\
\text { DNA }\end{array}$ & No & - & $5 \mathrm{~min}$ & - & $8.3 \cdot 10^{-11}$ & 2021 & [220] \\
\hline $\begin{array}{l}\mathrm{PGE} / \mathrm{RGO} / \mathrm{AuN} \\
\mathrm{Ps} \text { (3-electrode) }\end{array}$ & EIS & $\begin{array}{c}\text { 22-base } \\
\text { DNA }\end{array}$ & No & - & $30 \mathrm{~min}$ & 1,2,3-base & $1.3 \cdot 10^{-10}$ & 2021 & [221] \\
\hline $\begin{array}{c}\text { ITO } \\
\text { /PPy/AuNp/Cys } \\
\text { (3-electrode) }\end{array}$ & EIS & $\begin{array}{c}\text { 28-base } \\
\text { DNA }\end{array}$ & No & $2 \mu \mathrm{L}$ & $15 \mathrm{~min}$ & - & $5.7 \cdot 10^{-14}$ & 2021 & [222] \\
\hline $\begin{array}{c}\mathrm{CPE} / \mathrm{Pb}-\mathrm{IIP} / \\
\text { AuNPs } \\
\text { (3-electrode) }\end{array}$ & DPV & $\begin{array}{c}\text { 20-base } \\
\text { DNA }\end{array}$ & No & $5 \mu \mathrm{L}$ & $45 \mathrm{~min}$ & $\begin{array}{c}1,2,3,4 \text {-bas } \\
\mathrm{e}\end{array}$ & $3.0 \cdot 10^{-16}$ & 2021 & [223] \\
\hline
\end{tabular}




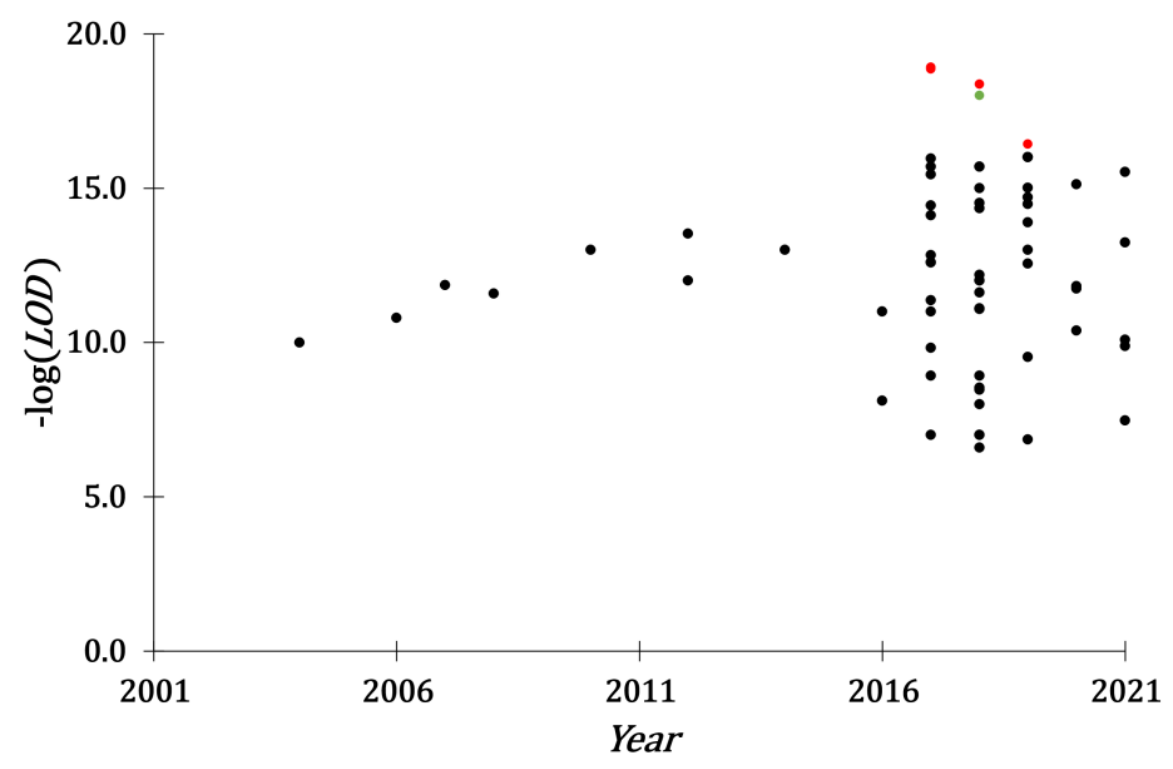

Fig. 17. $L O D$ evolution of electrochemical DNA-biosensors based on faradic resistance increase. Green: attomolar LOD. Red: attomolar detection but dilution of nucleic acid sample beyond Avogadro number.

Twenty-one studies reported a LOD in the femtomolar range, five studies a LOD in the attomolar range and the lower reported LOD is equal to $1.2 \cdot 10^{-19} \mathrm{~mol} / \mathrm{L}$, unfortunately, the dilution of nucleic acid sample is beyond Avogadro number for 3 of the 4 lowest LOD.

\section{Critical analysis of the lowest LOD}

The performances of transduction pathway are summarized in Table 8. It should be pointed out that (i) The number of studies is indicated; (ii) The LOD of the electrochemical DNA-biosensors reviewed herein were examined for each transduction pathway: the works for which dilution of nucleic acid sample beyond Avogadro number were not taken into accounts and the lowest LOD is considered if the detection was performed at least three times; (iii) The selectivity criterion is the ratio of biosensors allowing single mismatch detection.

Table 8. Comparison between biosensor transduction pathways for nucleic acid detection

\begin{tabular}{|c|c|c|c|}
\hline Transduction & $\begin{array}{c}\text { Number of } \\
\text { biosensors }\end{array}$ & $\begin{array}{c}\text { Reproducible } \\
\text { LOD (mol/L) }\end{array}$ & $\begin{array}{c}\text { Mismatch } \\
\text { detection } \\
\text { ratio }\end{array}$ \\
\hline Guanine oxidation & 22 & $10^{-14}$ & $41 \%$ \\
\hline
\end{tabular}




\begin{tabular}{|c|c|l|l|}
\hline Non-faradic & 35 & $10^{-16}$ & $40 \%$ \\
\hline Probe labeling & 22 & $10^{-16}$ & $50 \%$ \\
\hline LRET & 46 & $10^{-16}$ & $80 \%$ \\
\hline Catalyzed LRET & 7 & $10^{-13}$ & $86 \%$ \\
\hline Conducting Polymers & 21 & $10^{-16}$ & $33 \%$ \\
\hline Resistance increase & 66 & $10^{-16}$ & $68 \%$ \\
\hline
\end{tabular}

A significative number of studies was reported for 6 transduction pathways, the number of studies using catalyzed long-range electron transfer (LRET) is low. The reproducible LOD of detection is in the $10^{-16} \mathrm{~mol} / \mathrm{L}$ range and is the same for 5 transduction pathways. The LOD of the biosensors using guanine oxidation is higher and the LOD of the biosensors using catalyzed LRET is higher but this LOD is not relevant as the number of studies is not yet significative. It means that electrochemical DNA biosensor is not a mature technology to perform direct nucleic acid detection without PCR. The selectivity is higher for LRET transduction, high for resistance increase transduction and average for other transduction pathways. The more solid transduction pathway is long-range electron transfer (i.e. without catalysis), allowing reproducible detection and mismatch detection in the fentomolar range $\left(10^{-16} \mathrm{~mol} / \mathrm{L}\right)$.

\section{Conclusions}

Over the past three decades, electrochemical DNA biosensors based on different transduction pathways have been developed rapidly. Although many exciting results have been achieved, further efforts are still needed to improve the performance of electrochemical techniques in the field of DNA analysis. An overview of electrochemical transduction pathways of DNA electrochemical biosensors and the evolution of the detection limits were provided in this review and aimed to develop high accurate and sensitive biosensing platforms to promote the application of electrochemical DNA biosensors in clinical diagnosis. The evolution of the detection limits of electrochemical DNA biosensors shows that many breakthroughs were achieved for each transduction pathway. Low detection limits, in the femtomolar range, are obtained for biosensors based direct guanine oxidation, non-faradaic oxidation, redox probe labelling, long-range electron transfer, conducting polymer, and faradaic resistance increase, which the LOD based on long-range electron transfer was the lowest and in the attomolar range. Nevertheless, as previously mentioned, biosensors based on conducting polymer and on faradaic resistance increase are less interesting because of material aging and of signal decrease during the detection event, respectively. 
Despite important advances in DNA electrochemical detection in different transduction pathways, there are still some important problems and challenges. Constructing a biosensor with simple design and strong anti-interference ability, while can obviously improve the sensitivity and selectivity performance, especially allow the detection of mismatch, are still research hotspots in the future. Our opinion is that biosensors based on long-range electron transfer and non-faradaic transduction are the more interesting for DNA detection, not only because of the low detection limit, but also the simplified electrode assembly and detection methods, which will further promote the construction of miniaturized and portable sensors. In addition, it is important to underline that electrochemical DNA biosensors based on long-range electron transfer are especially interesting as they allow single-mismatch detection at room temperature, which makes this transduction pathway useful for constructing electrochemical biosensors for DNA immunoassay applications and clinical diagnostics.

\section{Acknowledgements}

YuanYuan Zhang acknowledges the China Scholarship Council for PhD grant.

\section{Compliance with Ethical Standards}

We certify compliance of this review and we do not have any conflict of interest to report.

\section{References}

1. Ho TH, Guillon FX, Bigey P, Bedioui F, Lazerges M. Analysis of the evolution of the detection limits of electrochemical nucleic acid biosensors II. Anal Bioanal Chem. 2017;409(18):4335-52. https://doi.org/10.1007/s00216-017-0377-8.

2. Lazerges M, Bedioui F. Analysis of the evolution of the detection limits of electrochemical DNA biosensors. Anal Bioanal Chem. 2013;405(11):3705-14. https://doi.org/10.1007/s00216-012-6672-5.

3. Wang J, Rivas G, Fernandes JR, Paz JLL, Jiang M, Waymire R. Indicator-free electrochemical DNA hybridization biosensor. Anal Chim Acta. 1998;375(3):197-203. https://doi.org/10.1016/S0003-2670(98)00503-0.

4. Cai X, Rivas G, Shirashi H, Farias P, Wang J, Tomschik M et al. Electrochemical analysis of formation of polynucleotide complexes in solution and at electrode surfaces. Anal Chim Acta. 1997;344(1-2):65-76. https://doi.org/10.1016/S0003-2670(97)00007-X.

5. Wang J, Kawde A-N. Pencil-based renewable biosensor for label-free electrochemical detection of DNA hybridization. Anal Chim Acta. 2001;431(2):219-24. https://doi.org/10.1016/S0003-2670(00)01318-0.

6. Lucarelli F, Marrazza G, Palchetti I, Cesaretti S, Mascini M. Coupling of an indicator-free electrochemical DNA biosensor with polymerase chain reaction for the detection of DNA sequences related to the apolipoprotein E. Anal Chim Acta. 2002;469(1):93-9. https://doi.org/10.1016/S0003-2670(02)00605-0.

7. Ozkan D, Erdem A, Kara P, Kerman K, Meric B, Hassmann J et al. Allele-specific genotype detection of factor V Leiden mutation from polymerase chain reaction amplicons based on label-free electrochemical genosensor. Anal Chem. 2002;74(23):5931-6. https://doi.org/10.1021/ac0257905.

8. Ariksoysal DO, Karadeniz H, Erdem A, Sengonul A, Sayiner AA, Ozsoz M. Label-free electrochemical hybridization genosensor for the detection of hepatitis B virus genotype on the development of lamivudine resistance. Anal Chem. 2005;77(15):4908-17. https://doi.org/10.1021/ac050022+.

9. Erdem A, Papakonstantinou P, Murphy H. Direct DNA hybridization at disposable graphite electrodes modified with carbon nanotubes. Anal Chem. 2006;78(18):6656-9. https://doi.org/10.1021/ac060202z. 
10. Arora K, Prabhakar N, Chand S, Malhotra B. Immobilization of single stranded DNA probe onto polypyrrole-polyvinyl sulfonate for application to DNA hybridization biosensor. Sensors Actuators B Chem. 2007;126(2):655-63. https://doi.org/10.1016/j.snb.2007.04.029.

11. Muti M, Kuralay F, Erdem A, Abaci S, Yumak T, Sinağ A. Tin oxide nanoparticles-polymer modified single-use sensors for electrochemical monitoring of label-free DNA hybridization. Talanta. 2010;82(5):1680-6. https://doi.org/10.1016/j.talanta.2010.07.040.

12. Alipour E, Pournaghi-Azar MH, Parvizi M, Golabi SM, Hejazi MS. Electrochemical detection and discrimination of single copy gene target DNA in non-amplified genomic DNA. Electrochim Acta. 2011;56(5):1925-31. https://doi.org/10.1016/j.electacta.2010.11.092.

13. Tajik S, Taher MA, Beitollahi H. Mangiferin DNA biosensor using double-stranded DNA modified pencil graphite electrode based on guanine and adenine signals. J Electroanal Chem. 2014;720-721:134-8. https://doi.org/10.1016/j.jelechem.2014.03.039.

14. Ozkan-Ariksoysal D, Kayran YU, Yilmaz FF, Ciucu AA, David IG, David V et al. DNA-wrapped multi-walled carbon nanotube modified electrochemical biosensor for the detection of Escherichia coli from real samples. Talanta. 2017;166:27-35. https://doi.org/10.1016/j.talanta.2017.01.005.

15. Ahour F, Shamsi A. Electrochemical label-free and sensitive nanobiosensing of DNA hybridization by graphene oxide modified pencil graphite electrode. Anal Biochem. 2017;532:64-71. https://doi.org/10.1016/j.ab.2017.06.004.

16. Isin D, Eksin E, Erdem A. Graphene oxide modified single-use electrodes and their application for voltammetric miRNA analysis. Mater Sci Eng C. 2017;75:1242-9. https://doi.org/10.1016/j.msec.2017.02.166.

17. Tanik NA, Demirkan E, Aykut Y. Guanine oxidation signal enhancement in DNA via a polyacrylonitrile nanofiber-coated and cyclic voltammetry-treated pencil graphite electrode. J Phys Chem Solids. 2018;118:73-9. https://doi.org/10.1016/j.jpcs.2018.03.001.

18. Eksin E, Erdem A. Electrochemical detection of microRNAs by graphene oxide modified disposable graphite electrodes. J Electroanal Chem. 2018;810:232-8. https://doi.org/10.1016/j.jelechem.2018.01.015.

19. Elhakim HKA, Azab SM, Fekry AM. A novel simple biosensor containing silver nanoparticles/propolis (bee glue) for microRNA let-7a determination. Materials Science and Engineering C, Materials for Biological Applications. 2018;92:489-95. https://doi.org/10.1016/j.msec.2018.06.063.

20. Subak H, Ozkan-Ariksoysal D. Label-free electrochemical biosensor for the detection of Influenza genes and the solution of guanine-based displaying problem of DNA hybridization. Sensors Actuators B Chem. 2018;263:196-207. https://doi.org/10.1016/j.snb.2018.02.089.

21. Erdem A, Eksin E. Zip nucleic acid based single-use biosensor for electrochemical detection of Factor V Leiden mutation. Sensors Actuators B Chem. 2019;288:634-40. https://doi.org/10.1016/j.snb.2019.03.008.

22. Yaralı E, Kanat E, Erac Y, Erdem A. Ionic liquid modified single- use electrode developed for voltammetric detection of miRNA- 34a and its application to real samples. Electroanalysis. 2020;32(2):384-93. https://doi.org/10.1002/elan.201900353.

23. Azab SM, Elhakim HK, Fekry AM. The strategy of nanoparticles and the flavone chrysin to quantify miRNA-let 7a in zepto-molar level: Its application as tumor marker. J Mol Struct. 2019;1196:647-52. https://doi.org/10.1016/j.molstruc.2019.06.111.

24. Dagci Kiransan K, Topçu E. Conducting polymer-reduced graphene oxide sponge electrode for electrochemical detection based on DNA hybridization. ACS Appl Nano Mater. 2020;3(6):5449-62. https://doi.org/10.1021/acsanm.0c00782.

25. Berney H, West J, Haefele E, Alderman J, Lane W, Collins J. A DNA diagnostic biosensor: development, characterisation and performance. Sensors Actuators B Chem. 2000;68(1-3):100-8. https://doi.org/10.1016/S0925-4005(00)00468-8.

26. Guiducci C, Stagni C, Zuccheri G, Bogliolo A, Benini L, Samor1 L et al. DNA detection by integrable electronics. Biosens Bioelectron. 2004;19(8):781-7. https://doi.org/10.1016/s0956-5663(03)00266-5.

27. Zebda A, Stambouli V, Labeau M, Guiducci C, Diard JP, Le Gorrec B. Metallic oxide $\mathrm{CdIn}_{2} \mathrm{O}_{4}$ films for the label free electrochemical detection of DNA hybridization. Biosens Bioelectron. 2006;22(2):178-84. https://doi.org/10.1016/j.bios.2005.12.012.

28. Hassen WM, Chaix C, Abdelghani A, Bessueille F, Leonard D, Jaffrezic-Renault N. An impedimetric DNA sensor based on functionalized magnetic nanoparticles for HIV and HBV detection. Sensors Actuators B Chem. 2008;134(2):755-60. https://doi.org/10.1016/j.snb.2008.06.020.

29. Martinovic J, van Wyk J, Mapolie S, Jahed N, Baker P, Iwuoha E. Electrochemical and spectroscopic properties of dendritic cobalto-salicylaldiimine DNA biosensor. Electrochim Acta. 2010;55(14):4296-302. https://doi.org/10.1016/j.electacta.2009.06.065.

30. Sahoo P, Suresh S, Dhara S, Saini G, Rangarajan S, Tyagi AK. Direct label free ultrasensitive impedimetric DNA biosensor using dendrimer functionalized GaN nanowires. Biosens Bioelectron. 2013;44:164-70. https://doi.org/10.1016/j.bios.2013.01.023.

31. Nowicka AM, Fau M, Rapecki T, Donten M. Polypyrrole-Au nanoparticles composite as suitable platform for DNA biosensor with electrochemical impedance spectroscopy detection. Electrochim Acta. 2014;140:65-71. https://doi.org/10.1016/j.electacta.2014.03.187.

32. Cai B, Wang S, Huang L, Ning Y, Zhang Z, Zhang G-J. Ultrasensitive label-free detection of PNA-DNA hybridization by reduced graphene oxide field-effect transistor biosensor. ACS Nano. 2014;8(3):2632-8. https://doi.org/10.1021/nn4063424.

33. Chen C-M, Lu MS-C. A CMOS capacitive biosensor array for highly sensitive detection of pathogenic avian influenza DNA. 2017 19th International Conference on Solid-State Sensors, Actuators and Microsystems (TRANSDUCERS); 2017; https://doi.org/10.1109/TRANSDUCERS.2017.7994376. 
34. Wang L, Veselinovic M, Yang L, Geiss BJ, Dandy DS, Chen T. A sensitive DNA capacitive biosensor using interdigitated electrodes. Biosens Bioelectron. 2017;87:646-53. https://doi.org/10.1016/j.bios.2016.09.006.

35. Cheng C, Oueslati R, Wu J, Chen J, Eda S. Capacitive DNA sensor for rapid and sensitive detection of whole genome human herpesvirus- 1 dsDNA in serum. Electrophoresis. 2017;38(12):1617-23. https://doi.org/10.1002/elps.201700043.

36. Xu S, Zhan J, Man B, Jiang S, Yue W, Gao S et al.. Real-time reliable determination of binding kinetics of DNA hybridization using a multi-channel graphene biosensor. Nat Commun. 2017;8:14902. https://doi.org/10.1038/ncomms14902. 37. Tran TL, Nguyen TT, Tran TTH, Tran QT, Mai AT. Detection of influenza A virus using carbon nanotubes field effect transistor based DNA sensor. Physica E. 2017;93:83-6. https://doi.org/10.1016/j.physe.2017.05.019.

38. Xuan CT, Thuy NT, Luyen TT, Huyen TT, Tuan MA. Carbon nanotube field-effect transistor for DNA sensing. J Electron Mater. 2017;46(6):3507-11. https://doi.org/10.1007/s11664-016-5238-2.

39. Tao W, Lin P, Hu J, Ke S, Song J, Zeng X. A sensitive DNA sensor based on an organic electrochemical transistor using a peptide nucleic acid-modified nanoporous gold gate electrode. RSC Adv. 2017;7(82):52118-24. https://doi.org/ 10.1039 / C7RA09832D

40. Xu S, Jiang S, Zhang C, Yue W, Zou Y, Wang G et al. Ultrasensitive label-free detection of DNA hybridization by sapphire-based graphene field-effect transistor biosensor. Appl Surf Sci. 2018;427:1114-9. https://doi.org/10.1016/j.apsusc.2017.09.113.

41. Mei J, Li Y-T, Zhang H, Xiao M-M, Ning Y, Zhang Z-Y et al. Molybdenum disulfide field-effect transistor biosensor for ultrasensitive detection of DNA by employing morpholino as probe. Biosens Bioelectron. 2018;110:71-7. https://doi.org/10.1016/j.bios.2018.03.043.

42. Majd SM, Salimi A, Astinchap B. The development of radio frequency magnetron sputtered p-type nickel oxide thin film field-effect transistor device combined with nucleic acid probe for ultrasensitive label-free HIV-1 gene detection. Sensors Actuators B Chem. 2018;266:178-86. https://doi.org/10.1016/j.snb.2018.03.111.

43. Shariati M. The field effect transistor DNA biosensor based on ITO nanowires in label-free hepatitis B virus detecting compatible with CMOS technology. Biosens Bioelectron. 2018;105:58-64. https://doi.org/10.1016/j.bios.2018.01.022.

44. Tian M, Xu S, Zhang J, Wang X, Li Z, Liu H et al. RNA detection based on graphene field-effect transistor biosensor. Adv Cond Matter Phys. 2018;2018. https://doi.org/10.1155/2018/8146765.

45. Majd SM, Salimi A, Ghasemi F. An ultrasensitive detection of miRNA-155 in breast cancer via direct hybridization assay using two-dimensional molybdenum disulfide field-effect transistor biosensor. Biosens Bioelectron. 2018;105:6-13. https://doi.org/10.1016/j.bios.2018.01.009.

46. Peng J, He T, Sun Y, Liu Y, Cao Q, Wang Q et al. An organic electrochemical transistor for determination of microRNA21 using gold nanoparticles and a capture DNA probe. Microchim Acta. 2018;185(9):408. https://doi.org/10.1007/s00604-018-2944-X.

47. Bronder TS, Jessing MP, Poghossian A, Keusgen M, Schoning MJ. Detection of PCR-amplified tuberculosis DNA fragments with polyelectrolyte-modified field-effect sensors. Anal Chem. 2018;90(12):7747-53. https://doi.org/10.1021/acs.analchem.8b01807.

48. Chen Y-W, Tai T-Y, Hsu C-P, Sarangadharan I, Pulikkathodi AK, Wang H-L et al. Direct detection of DNA using electrical double layer gated high electron mobility transistor in high ionic strength solution with high sensitivity and specificity. Sensors Actuators B Chem. 2018;271:110-7. https://doi.org/10.1016/j.snb.2018.05.119.

49. Li S, Huang K, Fan Q, Yang S, Shen T, Mei T et al. Highly sensitive solution-gated graphene transistors for label-free DNA detection. Biosens Bioelectron. 2019;136:91-6. https://doi.org/10.1016/j.bios.2019.04.034.

50. Nguyet NT, Van Thu V, Lan H, Trung T, Le A-T, Pham V-H et al. Simple label-free DNA sensor based on $\mathrm{CeO}_{2}$ nanorods decorated with Ppy nanoparticles. J Electron Mater. 2019;48(10):6231-9. https://doi.org/10.1007/s11664-019-07414-0.

51. Liu J, Chen X, Wang Q, Xiao M, Zhong D, Sun W et al. Ultrasensitive monolayer $\mathrm{MoS}_{2}$ field-effect transistor based DNA sensors for screening of down syndrome. Nano Lett. 2019;19(3):1437-44. https://doi.org/10.1021 / acs.nanolett.8b03818.

52. Bronder TS, Poghossian A, Jessing MP, Keusgen M, Schoning MJ. Surface regeneration and reusability of label-free DNA biosensors based on weak polyelectrolyte-modified capacitive field-effect structures. Biosens Bioelectron. 2019;126:510-7. https://doi.org/10.1016/j.bios.2018.11.019.

53. Tian M, Qiao M, Shen C, Meng F, Frank LA, Krasitskaya VV et al. Highly-sensitive graphene field effect transistor biosensor using PNA and DNA probes for RNA detection. Appl Surf Sci. 2020;527:146839. https://doi.org/10.1016/j.apsusc.2020.146839.

54. Lee C, Lu MS-C. CMOS ion sensitive field effect transistors for detection of DNA hybridization under debye screen effect. 2020 IEEE 33rd International Conference on Micro Electro Mechanical Systems (MEMS); 2020; https://doi.org/10.1109/MEMS46641.2020.9056272.

55. Gao J, Gao Y, Han Y, Pang J, Wang C, Wang Y et al. Ultrasensitive label-free miRNA sensing based on a flexible graphene field-effect transistor without functionalization. ACS Appl Electron Mater. 2020;2(4):1090-8. https://doi.org/10.1021/acsaelm.0c00095.

56. Deshmukh R, Prusty AK, Roy U, Bhand S. A capacitive DNA sensor for sensitive detection of Escherichia coli O157:H7 in potable water based on the z3276 genetic marker: fabrication and analytical performance. Analyst. 2020;145(6):2267-78. https://doi.org/10.1039/c9an02291k.

57. Mello HJNPD, Junior BB, Mulato M. Polyaniline-based field effect transistor for DNA/RNA biomarker sensing: Comparison to electrochemical impedance and inorganic layer. Sens Actuator A Phys. 2021;318:112481. https://doi.org/10.1016/j.sna.2020.112481.

58. Macchia E, Manoli K, Di Franco C, Picca RA, Österbacka R, Palazzo G et al. Organic field-effect transistor platform for label-free, single-molecule detection of genomic biomarkers. ACS Sens. 2020;5(6):1822-30. https://doi.org/10.1021/acssensors.0c00694. 
59. Kim S, Park S, Cho YS, Kim Y, Tae JH, No TI et al. Electrical cartridge sensor enables reliable and direct identification of microRNAs in urine of patients. ACS Sens. 2021;6(3):833-41. https://doi.org/10.1021/acssensors.0c01870.

60. Huang TJ, Liu M, Knight LD, Grody WW, Miller JF, Ho CM. An electrochemical detection scheme for identification of single nucleotide polymorphisms using hairpin-forming probes. Nucleic Acids Res. 2002;30(12):e55-e55. https://doi.org/10.1093/nar/gnf054.

61. Canady TD, Berlyoung AS, Martinez JA, Emanuelson C, Telmer CA, Bruchez MP et al. Enhanced hybridization selectivity using structured gammaPNA probes. Molecules. 2020;25(4):970. https://doi.org/10.3390/molecules25040970.

62. Xu C, Cai H, He P, Fang Y. Electrochemical detection of sequence-specific DNA using a DNA probe labeled with aminoferrocene and chitosan modified electrode immobilized with ssDNA. Analyst. 2001;126(1):62-5. https://doi.org/10.1039/b005847p.

63. Fan C, Plaxco KW, Heeger AJ. Electrochemical interrogation of conformational changes as a reagentless method for the sequence-specific detection of DNA. P Nati Acad Sci USA. 2003;100(16):9134-7. https://doi.org/10.1073/pnas.1633515100. 64. Jenkins DM, Chami B, Kreuzer M, Presting G, Alvarez AM, Liaw BY. Hybridization probe for femtomolar quantification of selected nucleic acid sequences on a disposable electrode. Anal Chem. 2006;78(7):2314-8. https://doi.org/10.1021/ac051619s.

65. Jin Y, Yao X, Liu Q, Li J. Hairpin DNA probe based electrochemical biosensor using methylene blue as hybridization indicator. Biosens Bioelectron. 2007;22(6):1126-30. https://doi.org/10.1016/j.bios.2006.04.011.

66. Farjami E, Clima L, Gothelf K, Ferapontova EE. "Off-on" electrochemical hairpin-DNA-based genosensor for cancer diagnostics. Anal Chem. 2011;83(5):1594-602. https://doi.org/10.1021/ac1032929.

67. Salamifar SE, Lai RY. Fabrication of electrochemical DNA sensors on gold-modified recessed platinum nanoelectrodes. Anal Chem. 2014;86(6):2849-52. https://doi.org/10.1021/ac403816h.

68. Qian Y, Tang D, Du L, Zhang Y, Zhang L, Gao F. A novel signal-on electrochemical DNA sensor based on target catalyzed hairpin assembly strategy. Biosens Bioelectron. 2015;64:177-81. https://doi.org/10.1016/j.bios.2014.09.001.

69. Li S, Qiu W, Zhang X, Ni J, Gao F, Wang Q. A high-performance DNA biosensor based on the assembly of gold nanoparticles on the terminal of hairpin-structured probe DNA. Sensors Actuators B Chem. 2016;223:861-7. https://doi.org/10.1016/j.snb.2015.09.121.

70. Zhan F, Liao X, Gao F, Qiu W, Wang Q. Electroactive crown ester-Cu ${ }^{2+}$ complex with in-situ modification at molecular beacon probe serving as a facile electrochemical DNA biosensor for the detection of CaMV 35s. Biosens Bioelectron. 2017;92:589-95. https://doi.org/10.1016/j.bios.2016.10.055.

71. Hong N, Cheng L, Wei B, Chen C, He LL, Ceng J et al. An electrochemical DNA sensor without electrode pre-modification. Biosens Bioelectron. 2017;91:110-4. https://doi.org/10.1016/j.bios.2016.10.008.

72. Lotfi Zadeh Zhad HR, Lai RY. Hexavalent chromium as an electrocatalyst in DNA sensing. Anal Chem. 2017;89(24):13342-8. https://doi.org/10.1021/acs.analchem.7b03514.

73. Teengam P, Siangproh W, Tuantranont A, Henry CS, Vilaivan T, Chailapakul O. Electrochemical paper-based peptide nucleic acid biosensor for detecting human papillomavirus. Anal Chim Acta. 2017;952:32-40. https://doi.org/10.1016/j.aca.2016.11.071.

74. Li Q, Zhao C, Zheng Z, Weng S, Chen Q, Liu Q et al. A signal-off double probes electrochemical DNA sensor for the simultaneous detection of Legionella and Legionella pneumophila. J Electroanal Chem. 2017;788:23-8. https://doi.org/10.1016/j.jelechem.2017.01.050.

75. Liu L, Chang Y, Xia N, Peng P, Zhang L, Jiang M et al. Simple, sensitive and label-free electrochemical detection of microRNAs based on the in situ formation of silver nanoparticles aggregates for signal amplification. Biosens Bioelectron. 2017;94:235-42. https://doi.org/10.1016/j.bios.2017.02.041.

76. Pursey JP, Chen Y, Stulz E, Park MK, Kongsuphol P. Microfluidic electrochemical multiplex detection of bladder cancer DNA markers. Sensors Actuators B Chem. 2017;251:34-9. https://doi.org/10.1016/j.snb.2017.05.006.

77. Liu S, Su W, Li Y, Zhang L, Ding X. Manufacturing of an electrochemical biosensing platform based on hybrid DNA hydrogel: Taking lung cancer-specific miR-21 as an example. Biosens Bioelectron. 2018;103:1-5. https://doi.org/10.1016/j.bios.2017.12.021.

78. Jampasa S, Siangproh W, Laocharoensuk R, Yanatatsaneejit P, Vilaivan T, Chailapakul O. A new DNA sensor design for the simultaneous detection of HPV type 16 and 18 DNA. Sensors Actuators B Chem. 2018;265:514-21. https://doi.org/10.1016/j.snb.2018.03.045.

79. Yammouri G, Mohammadi H, Amine A. A highly sensitive electrochemical biosensor based on carbon black and gold nanoparticles modified pencil graphite electrode for microRNA-21 detection. Chemistry Africa. 2019;2(2):291-300. https://doi.org/10.1007/s42250-019-00058-x.

80. Chandra S, Adeloju S. A new sensor for detecting microrna 133B (Parkinson's disease biomarker). Sensors International. 2020;1:100005. https://doi.org/10.1016/j.sintl.2020.100005.

81. Su S, Ma J, Xu Y, Pan H, Zhu D, Chao J et al. Electrochemical Analysis of Target-Induced Hairpin-Mediated Aptamer Sensors. ACS Appl Mater Interfaces. 2020;12(42):48133-9. https://doi.org/10.1021/acsami.0c12897.

82. Zhan F, Liao X, Wang Q, Sun W. A subfemtomolar electrochemical DNA biosensor realized by in-situ grafting of gold nanoparticle/neutral red on the terminal of hairpin probe as the signal tag. Microchem J. 2021;164:106079. https://doi.org/10.1016/j.microc.2021.106079.

83. Marchlewicz K, Ostrowska I, Oszwałdowski S, Zasada A, Ziółkowski R, Malinowska E. Molecular diagnostic of toxigenic Corynebacterium diphtheriae strain by DNA sensor potentially suitable for electrochemical Point-of-Care diagnostic. Talanta. 2021;227:122161. https://doi.org/10.1016/j.talanta.2021.122161.

84. Hejazi MS, Raoof JB, Ojani R, Golabi SM, Asl EH. Brilliant cresyl blue as electroactive indicator in electrochemical DNA oligonucleotide sensors. Bioelectrochemistry. 2010;78(2):141-6. https://doi.org/10.1016/j.bioelechem.2009.09.004. 
85. Wang J, Li S, Zhang Y. A sensitive DNA biosensor fabricated from gold nanoparticles, carbon nanotubes, and zinc oxide nanowires on a glassy carbon electrode. Electrochim Acta. 2010;55(15):4436-40. https://doi.org/10.1016/j.electacta.2010.02.078.

86. Bo Y, Yang H, Hu Y, Yao T, Huang S. A novel electrochemical DNA biosensor based on graphene and polyaniline nanowires. Electrochim Acta. 2011;56(6):2676-81. https://doi.org/10.1016/j.electacta.2010.12.034.

87. Li F, Feng Y, Dong P, Yang L, Tang B. Gold nanoparticles modified electrode via simple electrografting of in situ generated mercaptophenyl diazonium cations for development of DNA electrochemical biosensor. Biosens Bioelectron. 2011;26(5):1947-52. https://doi.org/10.1016/j.bios.2010.07.076.

88. Wang L, Wang X, Chen X, Liu J, Liu S, Zhao C. Development of an electrochemical DNA biosensor with the DNA immobilization based on in situ generation of dithiocarbamate ligands. Bioelectrochemistry. 2012;88:30-5. https://doi.org/10.1016/j.bioelechem.2012.04.003.

89. Du M, Yang T, Li X, Jiao K. Fabrication of DNA/graphene/polyaniline nanocomplex for label-free voltammetric detection of DNA hybridization. Talanta. 2012;88:439-44. https://doi.org/10.1016/j.talanta.2011.10.054.

90. Shi L, Chu Z, Dong X, Jin W, Dempsey E. A highly oriented hybrid microarray modified electrode fabricated by a template-free method for ultrasensitive electrochemical DNA recognition. Nanoscale. 2013;5(21):10219-25. https://doi.org/10.1039/c3nr03097k.

91. Yola ML, Eren T, Atar N. A novel and sensitive electrochemical DNA biosensor based on Fe@Au nanoparticles decorated graphene oxide. Electrochim Acta. 2014;125:38-47. https://doi.org/10.1016/j.electacta.2014.01.074.

92. Li F, Peng J, Zheng Q, Guo X, Tang H, Yao S. Carbon nanotube-polyamidoamine dendrimer hybrid-modified electrodes for highly sensitive electrochemical detection of microRNA24. Anal Chem. 2015;87(9):4806-13. https://doi.org/10.1021/acs.analchem.5b00093.

93. Sun Y, He X, Ji J, Jia M, Wang Z, Sun X. A highly selective and sensitive electrochemical CS-MWCNTs/Au-NPs composite DNA biosensor for Staphylococcus aureus gene sequence detection. Talanta. 2015;141:300-6. https://doi.org/10.1016/j.talanta.2015.03.052.

94. Hajihosseini S, Nasirizadeh N, Hejazi MS, Yaghmaei P. An electrochemical DNA biosensor based on Oracet Blue as a label for detection of Helicobacter pylori. Int J Biol Macromol. 2016;91:911-7. https://doi.org/10.1016/j.ijbiomac.2016.04.009.

95. Su S, Wu Y, Zhu D, Chao J, Liu X, Wan Y et al. On-electrode synthesis of shape-controlled hierarchical flower-like gold nanostructures for efficient interfacial DNA assembly and sensitive electrochemical sensing of microRNA. Small. 2016;12(28):3794-3801. https://doi.org/10.1002/smll.201601066.

96. Sukumaran P, Veettil VT, Rajappa S, Li C-Z, Alwarappan S. Ionic liquid modified N-doped graphene as a potential platform for the electrochemical discrimination of DNA sequences. Sensors Actuators B Chem. 2017;247:556-63. https://doi.org/10.1016/j.snb.2017.03.078.

97. Yi X, Lu Z, Kong Y, Chen Z. Label-free electrochemical detection of microRNAs via intercalation of hemin into the DNA/RNA hybridization. Int J Electrochem Sci. 2017;12:2813-21. https://doi.org/10.20964/2017.04.33.

98. Gaiji H, Jolly P, Ustuner S, Goggins S, Abderrabba M, Frost CG et al. A peptide nucleic acid (PNA)- DNA ferrocenyl intercalator for electrochemical sensing. Electroanalysis. 2017;29(3):917-22. https://doi.org/10.1002/elan.201600576.

99. Huang Q, Lin X, Zhu J-J, Tong Q-X. Pd-Au@ carbon dots nanocomposite: Facile synthesis and application as an ultrasensitive electrochemical biosensor for determination of colitoxin DNA in human serum. Biosens Bioelectron. 2017;94:507-12. https://doi.org/10.1016/j.bios.2017.03.048.

100. Aghaei F, Seifati SM, Nasirizadeh N. Development of a DNA biosensor for the detection of phenylketonuria based on a screen-printed gold electrode and hematoxylin. Anal Methods. 2017;9(6):966-73. https://doi.org/10.1039/C6AY02853E.

101. Hui N, Sun X, Niu S, Luo X. PEGylated polyaniline nanofibers: antifouling and conducting biomaterial for electrochemical DNA sensing. ACS Appl Mater Interfaces. 2017;9(3):2914-23. https://doi.org/10.1021/acsami.6b11682.

102. Niu X, Zheng W, Yin C, Weng W, Li G, Sun W et al. Electrochemical DNA biosensor based on gold nanoparticles and partially reduced graphene oxide modified electrode for the detection of Listeria monocytogenes hly gene sequence. $\mathrm{J}$ Electroanal Chem. 2017;806:116-122. https://doi.org/10.1016/j.jelechem.2017.10.049.

103. Kaplan M, Kilic T, Guler G, Mandli J, Amine A, Ozsoz M. A novel method for sensitive microRNA detection: Electropolymerization based doping. Biosens Bioelectron. 2017;92:770-8. https://doi.org/10.1016/j.bios.2016.09.050.

104. Azimzadeh M, Nasirizadeh N, Rahaie M, Naderi-Manesh H. Early detection of Alzheimer's disease using a biosensor based on electrochemically-reduced graphene oxide and gold nanowires for the quantification of serum microRNA-137. RSC Adv. 2017;7(88):55709-19. https://doi.org/10.1039/C7RA09767K.

105. Loo AH, Chua CK, Pumera M. DNA biosensing with 3D printing technology. Analyst. 2017;142(2):279-83. https://doi.org/10.1039/C6AN02038K.

106. Rahman M, Heng LY, Futra D, Chiang CP, Rashid ZA, Ling TL. A highly sensitive electrochemical DNA biosensor from acrylic-gold nano-composite for the determination of arowana fish gender. Nanoscale Res Lett. 2017;12(1):484. https://doi.org/10.1186/s11671-017-2254-y.

107. Rahman M, Heng LY, Futra D, Ling TL. Ultrasensitive biosensor for the detection of Vibrio cholerae DNA with polystyrene-co-acrylic acid composite nanospheres. Nanoscale Res Lett. 2017;12(1):474. https://doi.org/10.1186/s11671-017-2236-0.

108. Esmaeili C, Heng LY, Chiang CP, Rashid ZA, Safitri E, Marugan RSPM. A DNA biosensor based on kappa-carrageenan-polypyrrole-gold nanoparticles composite for gender determination of Arowana fish (Scleropages formosus). Sensors Actuators B Chem. 2017;242:616-24. https://doi.org/10.1016/j.snb.2016.11.061.

109. Singhal C, Pundir C, Narang J. A genosensor for detection of consensus DNA sequence of Dengue virus using ZnO/Pt-Pd nanocomposites. Biosens Bioelectron. 2017;97:75-82. https://doi.org/10.1016/j.bios.2017.05.047.

110. Chen M, Su H, Mao L, Guo M, Tang J. Highly sensitive electrochemical DNA sensor based on the use of three-dimensional nitrogen-doped graphene. Mikrochim Acta. 2017;185(1):51. https://doi.org/10.1007/s00604-017-2588-2. 
111. Chen M, Wang Y, Su H, Mao L, Jiang X, Zhang T et al. Three-dimensional electrochemical DNA biosensor based on 3D graphene-Ag nanoparticles for sensitive detection of CYFRA21-1 in non-small cell lung cancer. Sensors Actuators B Chem. 2018;255:2910-8. https://doi.org/10.1016/j.snb.2017.09.111.

112. García-Mendiola T, Bravo I, López-Moreno JM, Pariente F, Wannemacher R, Weber K et al. Carbon nanodots based biosensors for gene mutation detection. Sensors Actuators B Chem. 2018;256:226-33. https://doi.org/10.1016/j.snb.2017.10.105.

113. Hua H, Liu Y, Guan X, Li Y. DNA nanosensors based on the use of single gold nanowire electrodes and methylene blue as an intercalator. Microchim Acta. 2018;185(2):152. https://doi.org/10.1007/s00604-018-2703-Z.

114. Tian L, Qian K, Qi J, Liu Q, Yao C, Song W et al. Gold nanoparticles superlattices assembly for electrochemical biosensor detection of microRNA-21. Biosens Bioelectron. 2018;99:564-70. https://doi.org/10.1016/j.bios.2017.08.035.

115. Yuan Y, Xun Z, Zhang B, Guan Y. Electrochemical signal enhancer fabricated using lysine- rich peptide for ultrasensitive electrochemical DNA biosensor analysis. Electroanalysis. 2019;31(4):607-10. https://doi.org/10.1002/elan.201800697.

116. Ling YP, Heng LY, Chee HY. A quantification strategy for DNA hybridization via measurement of adsorbed anthraquinone monosulphonic acid on silica nanospheres. Measurement. 2019;135:640-50. https://doi.org/10.1016/j.measurement.2018.12.026.

117. Gu Y, Tseng P-Y, Bi X, Yang JH. Quantification of DNA by a thermal-durable biosensor modified with conductive poly (3, 4-ethylenedioxythiophene). Sensors. 2018;18(11):3684. https://doi.org/10.3390/s18113684.

118. Nazari-Vanani R, Sattarahmady N, Yadegari H, Delshadi N, Hatam GR, Heli H. Electrochemical quantitation of Leishmania infantum based on detection of its kDNA genome and transduction of non-spherical gold nanoparticles. Anal Chim Acta. 2018;1041:40-9. https://doi.org/10.1016/j.aca.2018.08.036.

119. Ariffin EY, Lee YH, Futra D, Tan LL, Abd Karim NH, Ibrahim NNN et al. An ultrasensitive hollow-silica-based biosensor for pathogenic Escherichia coli DNA detection. Anal Bioanal Chem. 2018;410(9):2363-75. https://doi.org/10.1007/s00216-018-0893-1.

120. Akbarnia A, Zare HR. A voltammetric assay for microRNA-25 based on the use of amino-functionalized graphene quantum dots and ss-and ds-DNAs as gene probes. Microchim Acta. 2018;185(11):503. https://doi.org/10.1007/s00604-018-3037-6.

121. Wang J, Hui N. Electrochemical functionalization of polypyrrole nanowires for the development of ultrasensitive biosensors for detecting microRNA. Sensors Actuators B Chem. 2019;281:478-85. https://doi.org/10.1016/j.snb.2018.10.131. 122. Song J, Ni J, Wang Q, Chen H, Gao F, Lin Z et al. A planar and uncharged copper(II)-picolinic acid chelate: Its intercalation to duplex DNA by experimental and theoretical studies and electrochemical sensing application. Biosens Bioelectron. 2019;141:111405. https://doi.org/10.1016/j.bios.2019.111405.

123. Han S, Liu W, Yang S, Wang R. Facile and label-free electrochemical biosensors for microRNA detection based on DNA origami nanostructures. ACS omega. 2019;4(6):11025-31. https://doi.org/10.1021/acsomega.9b01166.

124. Erdem A, Eksin E, Kadikoylu G, Yildiz E. Voltammetric detection of miRNA hybridization based on electroactive indicator-cobalt phenanthroline. Int J Biol Macromol. 2020;158:819-25. https://doi.org/10.1016/j.ijbiomac.2020.04.168.

125. Fani M, Rezayi M, Meshkat Z, Rezaee SA, Makvandi M, Angali KA. A Novel electrochemical DNA biosensor based on a gold nanoparticles-reduced graphene oxide-polypyrrole nanocomposite to detect human T-lymphotropic virus-1. IEEE Sensors Journal. 2020. https://doi.org/10.1109 / JSEN.2020.2993274.

126. Ma W, Du H, Zhang M, Mori J, Ren X, Wang H et al. One-step synthesis of tunable zinc-based nanohybrids as an ultrasensitive DNA signal amplification platform. ACS Appl Mater Interfaces. 2019;12(2):2983-90. https://doi.org/10.1021/acsami.9b18973.

127. Mahmoodi P, Rezayi M, Rasouli E, Avan A, Gholami M, Mobarhan MG et al. Early-stage cervical cancer diagnosis based on an ultra-sensitive electrochemical DNA nanobiosensor for HPV-18 detection in real samples. J Nanobiotechnol. 2020;18(1):1-12. https://doi.org/10.1186/s12951-020-0577-9.

128. Niu X, Chen W, Wang X, Men Y, Wang Q, Sun W et al. A graphene modified carbon ionic liquid electrode for voltammetric analysis of the sequence of the Staphylococcus aureus nuc gene. Microchim Acta. 2018;185(3):167. https://doi.org/10.1007/s00604-018-2719-4.

129. Han Y, An F, Liu J, Kong J, Zhang X. Highly sensitive determination of DNA via a new type of electrochemical zirconium signaling probe. New J Chem. 2020;44(47):20770-5. https://doi.org/10.1039/D0NJ04405A.

130. Dharuman V, Hahn JH. Label free electrochemical DNA hybridization discrimination effects at the binary and ternary mixed monolayers of single stranded DNA/diluent/s in presence of cationic intercalators. Biosens Bioelectron. 2008;23(8):1250-8. https://doi.org/10.1016/j.bios.2007.11.015.

131. Fang Z, Kelley SO. Direct electrocatalytic mRNA detection using PNA-nanowire sensors. Anal Chem. 2009;81(2):612-7. https://doi.org/10.1021/ac801890f.

132. Wipawakarn P, Ju H, Wong DK. A label-free electrochemical DNA biosensor based on a Zr(IV)-coordinated DNA duplex immobilised on a carbon nanofibre|chitosan layer. Anal Bioanal Chem. 2012;402(9):2817-26. https://doi.org/10.1007/s00216-012-5733-0.

133. Lazerges M, Tal VT, Bigey P, Scherman D, Bedioui F. Electrochemical DNA-biosensors: Two-electrode setup well adapted for miniaturized devices. Sensors Actuators B Chem. 2013;182:510-3. https://doi.org/10.1016/j.snb.2013.02.098.

134. Nassi A, Guillon FX, Amar A, Hainque B, Amriche S, Maugé D et al. Electrochemical DNA-biosensors based on long-range electron transfer: optimization of the amperometric detection in the femtomolar range using two-electrode setup and ultramicroelectrode. Electrochim Acta. 2016;209:269-77. https://doi.org/10.1016/j.electacta.2016.04.144.

135. Horny MC, Lazerges M, Siaugue JM, Pallandre A, Rose D, Bedioui F et al. Electrochemical DNA biosensors based on long-range electron transfer: investigating the efficiency of a fluidic channel microelectrode compared to an ultramicroelectrode in a two-electrode setup. Lab Chip. 2016;16(22):4373-81. https://doi.org/10.1039/c6lc00869k. 
136. Farshchi F, Saadati A, Hasanzadeh M. Optimized DNA-based biosensor for monitoring Leishmania infantum in human plasma samples using biomacromolecular interaction: a novel platform for infectious disease diagnosis. Anal Methods. 2020;12(39):4759-68. https://doi.org/10.1039/D0AY01516D.

137. Korri-Youssoufi H, Yassar A. Electrochemical probing of DNA based on oligonucleotide-functionalized polypyrrole. Biomacromolecules. 2001;2(1):58-64. https://doi.org/10.1021/bm0000440.

138. Korri-Youssoufi H, Makrouf B. Electrochemical biosensing of DNA hybridization by ferrocenyl groups functionalized polypyrrole. Anal Chim Acta. 2002;469(1):85-92. https://doi.org/10.1016/S0003-2670(02)00539-1.

139. Cha J, Han JI, Choi Y, Yoon DS, Oh KW, Lim G. DNA hybridization electrochemical sensor using conducting polymer. Biosens Bioelectron. 2003;18(10):1241-7. https://doi.org/10.1016/s0956-5663(03)00088-5.

140. Ramanaviciene A, Ramanavicius A. Pulsed amperometric detection of DNA with an ssDNA/polypyrrole-modified electrode. Anal Bioanal Chem. 2004;379(2):287-93. https://doi.org/10.1007/s00216-004-2573-6.

141. Komarova E, Aldissi M, Bogomolova A. Direct electrochemical sensor for fast reagent-free DNA detection. Biosens Bioelectron. 2005;21(1):182-9. https://doi.org/10.1016/j.bios.2004.07.025.

142. Chen Y, Elling, Lee Y-1, Chong S-c. A Fast, Sensitive and label free electrochemical DNA sensor. J Phys Conf Ser. 2006;34:204-9. https://doi.org/10.1088/1742-6596/34/1/034.

143. dos Santos Riccardi C, Yamanaka H, Josowicz M, Kowalik J, Mizaikoff B, Kranz C. Label-free DNA detection based on modified conducting polypyrrole films at microelectrodes. Anal Chem. 2006;78(4):1139-45. https://doi.org/10.1021/ac051478u.

144. Reisberg S, Piro B, Noel V, Pham MC. Selectivity and sensitivity of a reagentless electrochemical DNA sensor studied by square wave voltammetry and fluorescence. Bioelectrochemistry. 2006;69(2):172-9. https://doi.org/10.1016/j.bioelechem.2005.12.007.

145. Bouchet A, Chaix C, Marquette CA, Blum LJ, Mandrand B. Cylinder-shaped conducting polypyrrole for labelless electrochemical multidetection of DNA. Biosens Bioelectron. 2007;23(5):735-40. https://doi.org/10.1016/j.bios.2007.06.018. 146. Peng H, Soeller C, Vigar NA, Caprio V, Travas-Sejdic J. Label-free detection of DNA hybridization based on a novel functionalized conducting polymer. Biosens Bioelectron. 2007;22(9-10):1868-73. https://doi.org/10.1016/j.bios.2006.07.010. 147. Tlili C, Jaffrezic-Renault NJ, Martelet C, Korri-Youssoufi H. Direct electrochemical probing of DNA hybridization on oligonucleotide-functionalized polypyrrole. Mater Sci Eng C. 2008;28(5-6):848-54. https://doi.org/10.1016/j.msec.2007.10.061.

148. Reisberg S, Dang LA, Nguyen QA, Piro B, Noel V, Nielsen PE et al. Label-free DNA electrochemical sensor based on a PNA-functionalized conductive polymer. Talanta. 2008;76(1):206-10. https://doi.org/10.1016/j.talanta.2008.02.044.

149. March G, Noël V, Piro Bt, Reisberg S, Pham M-C. Nanometric layers for direct, signal-on, selective, and sensitive electrochemical detection of oligonucleotides hybridization. J Am Chem Soc. 2008;130(47):15752-3. https://doi.org/10.1021/ja8047255.

150. Nie G, Zhang Y, Guo Q, Zhang S. Label-free DNA detection based on a novel nanostructured conducting

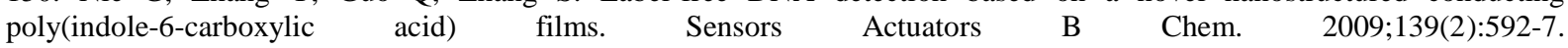
https://doi.org/10.1016/j.snb.2009.03.009.

151. Le HQ, Chebil S, Makrouf B, Sauriat-Dorizon H, Mandrand B, Korri-Youssoufi H. Effect of the size of electrode on electrochemical properties of ferrocene-functionalized polypyrrole towards DNA sensing. Talanta. 2010;81(4-5):1250-7. https://doi.org/10.1016/j.talanta.2010.02.017.

152. Tran HV, Piro B, Reisberg S, Anquetin G, Duc HT, Pham MC. An innovative strategy for direct electrochemical detection of microRNA biomarkers. Anal Bioanal Chem. 2014;406(4):1241-4. https://doi.org/10.1007/s00216-013-7292-4.

153. Bouffier L, Wang BS, Roget A, Livache T, Demeunynck M, Mailley P. Electrochemical transduction of DNA hybridization at modified electrodes by using an electroactive pyridoacridone intercalator. Anal Bioanal Chem. 2014;406(4):1163-72. https://doi.org/10.1007/s00216-013-7314-2.

154. Miodek A, Mejri N, Gomgnimbou M, Sola C, Korri-Youssoufi H. E-DNA sensor of Mycobacterium tuberculosis based on electrochemical assembly of nanomaterials (MWCNTs/PPy/PAMAM). Anal Chem. 2015;87(18):9257-64. https://doi.org/10.1021/acs.analchem.5b01761.

155. Galan T, Prieto-Simon B, Alvira M, Eritja R, Gotz G, Bauerle P et al. Label-free electrochemical DNA sensor using "click"-functionalized PEDOT electrodes. Biosens Bioelectron. 2015;74:751-6. https://doi.org/10.1016/j.bios.2015.07.037.

156. Tran HV, Nguyen ND, Piro B, Tran LT. Fabrication of a quinone containing layer on gold nanoparticles directed to a label-free and reagentless electrochemical miRNA sensor. Anal Methods. 2017;9(18):2696-702. https://doi.org/10.1039/C7AY00665A.

157. Yang L, Wang H, Lü H, Hui N. Phytic acid functionalized antifouling conducting polymer hydrogel for electrochemical detection of microRNA. Anal Chim Acta. 2020. https://doi.org/10.1016/j.aca.2020.05.025.

158. Zhu N, Zhang A, Wang Q, He P, Fang Y. Electrochemical detection of DNA hybridization using methylene blue and electro-deposited zirconia thin films on gold electrodes. Anal Chim Acta. 2004;510(2):163-8. https://doi.org/10.1016/j.aca.2004.01.017.

159. Feng KJ, Yang YH, Wang ZJ, Jiang JH, Shen GL, Yu RQ. A nano-porous $\mathrm{CeO}_{2} /$ Chitosan composite film as the immobilization matrix for colorectal cancer DNA sequence-selective electrochemical biosensor. Talanta. 2006;70(3):561-5. https://doi.org/10.1016/j.talanta.2006.01.009.

160. Yang J, Jiao K, Yang T. A DNA electrochemical sensor prepared by electrodepositing zirconia on composite films of single-walled carbon nanotubes and poly(2,6-pyridinedicarboxylic acid), and its application to detection of the PAT gene fragment. Anal Bioanal Chem. 2007;389(3):913-21. https://doi.org/10.1007/s00216-007-1450-5.

161. Yang T, Zhang W, Du M, Jiao K. A PDDA/poly(2,6-pyridinedicarboxylic acid)-CNTs composite film DNA electrochemical sensor and its application for the detection of specific sequences related to PAT gene and NOS gene. Talanta. 2008;75(4):987-94. https://doi.org/10.1016/j.talanta.2007.12.049. 
162. Lin L, Chen J, Lin Q, Chen W, Chen J, Yao H et al. Electrochemical biosensor based on nanogold-modified poly-eriochrome black T film for BCR/ABL fusion gene assay by using hairpin LNA probe. Talanta. 2010;80(5):2113-9. https://doi.org/10.1016/j.talanta.2009.11.017.

163. Jayakumar K, Rajesh R, Dharuman V, Venkatasan R, Hahn JH, Pandian SK. Gold nano particle decorated graphene core first generation PAMAM dendrimer for label free electrochemical DNA hybridization sensing. Biosens Bioelectron. 2012;31(1):406-12. https://doi.org/10.1016/j.bios.2011.11.001.

164. Wang Q, Gao F, Zhang X, Zhang B, Li S, Hu Z et al. Electrochemical characterization and DNA sensing application of a sphere-like $\mathrm{CeO}_{2}-\mathrm{ZrO}_{2}$ and chitosan nanocomposite formed on a gold electrode by one-step electrodeposition. Electrochim Acta. 2012;62:250-5. https://doi.org/10.1016/j.electacta.2011.12.020.

165. Xu CX, Zhai QG, Liu YJ, Huang KJ, Lu L, Li KX. A novel electrochemical DNA biosensor construction based on layered $\mathrm{CuS}$-graphene composite and $\mathrm{Au}$ nanoparticles. Anal Bioanal Chem. 2014;406(27):6943-51. https://doi.org/10.1007/s00216-014-7904-7.

166. Shahrokhian S, Salimian R, Kalhor HR. A simple label-free electrochemical DNA biosensor based on carbon nanotube-DNA interaction. RSC Adv. 2016;6(19):15592-8. https://doi.org/10.1039/C5RA20907B.

167. Torati SR, Reddy V, Yoon SS, Kim C. Electrochemical biosensor for Mycobacterium tuberculosis DNA detection based on gold nanotubes array electrode platform. Biosens Bioelectron. 2016;78:483-8. https://doi.org/10.1016/j.bios.2015.11.098.

168. Ye Y, Gao J, Zhuang H, Zheng H, Sun H, Ye Y et al. Electrochemical gene sensor based on a glassy carbon electrode modified with hemin-functionalized reduced graphene oxide and gold nanoparticle-immobilized probe DNA. Microchim Acta. 2017;184(1):245-52. https://doi.org/10.1007/s00604-016-1999-9.

169. Yammouri G, Mandli J, Mohammadi H, Amine A. Development of an electrochemical label-free biosensor for microRNA-125a detection using pencil graphite electrode modified with different carbon nanomaterials. J Electroanal Chem. 2017;806:75-81. https://doi.org/10.1016/j.jelechem.2017.10.012.

170. Bizid S, Blili S, Mlika R, Haj Said A, Korri-Youssoufi H. Direct electrochemical DNA sensor based on a new redox oligomer modified with ferrocene and carboxylic acid: Application to the detection of Mycobacterium tuberculosis mutant strain. Anal Chim Acta. 2017;994:10-8. https://doi.org/10.1016/j.aca.2017.09.022.

171. Low SS, Loh HS, Boey JS, Khiew PS, Chiu WS, Tan MTT. Sensitivity enhancement of graphene/zinc oxide nanocomposite-based electrochemical impedance genosensor for single stranded RNA detection. Biosens Bioelectron. 2017;94:365-73. https://doi.org/10.1016/j.bios.2017.02.038.

172. Gao N, Gao F, He S, Zhu Q, Huang J, Tanaka H et al. Graphene oxide directed in-situ deposition of electroactive silver nanoparticles and its electrochemical sensing application for DNA analysis. Anal Chim Acta. 2017;951:58-67. https://doi.org/10.1016/j.aca.2016.11.033.

173. Ribovski L, Zucolotto V, Janegitz BC. A label-free electrochemical DNA sensor to identify breast cancer susceptibility. Microchem J. 2017;133:37-42. https://doi.org/10.1016/j.microc.2017.03.011.

174. Kocak I, Şanal T, Hazer B. An electrochemical biosensor for direct detection of DNA using polystyrene-g-soya oil-g-imidazole graft copolymer. J Solid State Electr. 2017;21(5):1397-405. https://doi.org/10.1007/s10008-017-3504-8.

175. Zhu D, Liu W, Zhao D, Hao Q, Li J, Huang J et al. Label-free electrochemical sensing platform for microRNA-21 detection using thionine and gold nanoparticles co-functionalized MoS2 nanosheet. ACS Appl Mater Interfaces. 2017;9(41):35597-603. https://doi.org/10.1021/acsami.7b11385.

176. Asadzadeh-Firouzabadi A, Zare HR. Application of cysteamine-capped gold nanoparticles for early detection of lung cancer-specific miRNA (miR-25) in human blood plasma. Anal Methods. 2017;9(25):3852-61. https://doi.org/10.1039/C7AY01098B.

177. Senel M, Dervisevic M, Kokkokoğlu F. Electrochemical DNA biosensors for label-free breast cancer gene marker detection. Anal Bioanal Chem. 2019;411(13):2925-35. https://doi.org/10.1007/s00216-019-01739-9.

178. Mousavisani SZ, Raoof JB, Ojani R, Valiollahi R. Rapid detection of single nucleotide mutation in p53 gene based on gold nanoparticles decorated on graphene nanosheets. J Chem Sci. 2017;129(1):131-9. https://doi.org/10.1007/s12039-016-1198-6.

179. Karimizefreh A, Mahyari FA, VaezJalali M, Mohammadpour R, Sasanpour P. Impedimetic biosensor for the DNA of the human papilloma virus based on the use of gold nanosheets. Microchim Acta. 2017;184(6):1729-37. https://doi.org/10.1007/s00604-017-2173-8.

180. Falcone N, She Z, Chen C, Dong B, Yi D, Kraatz H-B. Demonstration of a tailorable and PCR-free detection of Enterococcus DNA isolated from soil samples. Anal Methods. 2017;9(10):1643-9. https://doi.org/10.1039/C6AY03309A.

181. Tripathy S, Vanjari SRK, Singh V, Swaminathan S, Singh SG. Electrospun manganese (III) oxide nanofiber based electrochemical DNA-nanobiosensor for zeptomolar detection of dengue consensus primer. Biosens Bioelectron. 2017;90:378-87. https://doi.org/10.1016/j.bios.2016.12.008.

182. Xu S, Zhang Y, Dong K, Wen J, Zheng C, Zhao S. Electrochemical DNA biosensor based on graphene oxide-chitosan hybrid nanocomposites for detection of Escherichia coli O157: H7. Int J Electrochem Sci. 2017;12:3443-58. https://doi.org/10.20964/2017.04.16.

183. Wang Y, Huang X, Li H, Guo L. Sensitive impedimetric DNA biosensor based on $(\mathrm{Nb}, \mathrm{V})$ codoped $\mathrm{TiO}_{2}$ for breast cancer susceptible gene detection. Mater Sci Eng C. 2017;77:867-73. https://doi.org/10.1016/j.msec.2017.03.260.

184. Shariati M, Ghorbani M, Sasanpour P, Karimizefreh A. An ultrasensitive label free human papilloma virus DNA biosensor using gold nanotubes based on nanoporous polycarbonate in electrical alignment. Anal Chim Acta. 2019;1048:31-41. https://doi.org/10.1016/j.aca.2018.09.062.

185. Khater M, de la Escosura-Muñiz A, Quesada-González D, Merkoçi A. Electrochemical detection of plant virus using gold nanoparticle-modified electrodes. Anal Chim Acta. 2019;1046:123-31. https://doi.org/10.1016/j.aca.2018.09.031.

186. Kangkamano T, Numnuam A, Limbut W, Kanatharana P, Vilaivan T, Thavarungkul P. Pyrrolidinyl PNA polypyrrole/silver nanofoam electrode as a novel label-free electrochemical miRNA-21 biosensor. Biosens Bioelectron. 2018;102:217-25. https://doi.org/10.1016/j.bios.2017.11.024. 
187. Manzano M, Viezzi S, Mazerat S, Marks RS, Vidic J. Rapid and label-free electrochemical DNA biosensor for detecting hepatitis A virus. Biosens Bioelectron. 2018;100:89-95. https://doi.org/10.1016/j.bios.2017.08.043.

188. Hong SA, Kim YJ, Kim SJ, Yang S. Electrochemical detection of methylated DNA on a microfluidic chip with nanoelectrokinetic pre-concentration. Biosens Bioelectron. 2018;107:103-10. https://doi.org/10.1016/j.bios.2018.01.067.

189. Ye Y, Xie J, Ye Y, Cao X, Zheng H, Xu X et al. A label-free electrochemical DNA biosensor based on thionine functionalized reduced graphene oxide. Carbon. 2018;129:730-7. https://doi.org/10.1016/j.carbon.2017.12.060.

190. Teengam P, Siangproh W, Tuantranont A, Vilaivan T, Chailapakul O, Henry CS. Electrochemical impedance-based DNA sensor using pyrrolidinyl peptide nucleic acids for tuberculosis detection. Anal Chim Acta. 2018;1044:102-9. https://doi.org/10.1016/j.aca.2018.07.045.

191. Lee J, Morita M, Takemura K, Park EY. A multi-functional gold/iron-oxide nanoparticle-CNT hybrid nanomaterial as virus DNA sensing platform. Biosens Bioelectron. 2018;102:425-31. https://doi.org/10.1016/j.bios.2017.11.052.

192. Singhal C, Khanuja M, Chaudhary N, Pundir C, Narang J. Detection of chikungunya virus DNA using two-dimensional $\mathrm{MoS}_{2}$ nanosheets based disposable biosensor. Sci Rep. 2018;8(1):1-11. https://doi.org/10.1038/s41598-018-25824-8.

193. Salahandish R, Ghaffarinejad A, Omidinia E, Zargartalebi H, Majidzadeh AK, Naghib SM et al. Label-free ultrasensitive detection of breast cancer miRNA-21 biomarker employing electrochemical nano-genosensor based on sandwiched AgNPs in PANI and N-doped graphene. Biosens Bioelectron. 2018;120:129-36. https://doi.org/10.1016/j.bios.2018.08.025.

194. Zhu B, Travas-Sejdic J. PNA versus DNA in electrochemical gene sensing based on conducting polymers: study of charge and surface blocking effects on the sensor signal. Analyst. 2018;143(3):687-94. https://doi.org/10.1039/C7AN01590A.

195. Boriachek K, Umer M, Islam MN, Gopalan V, Lam AK, Nguyen N-T et al. An amplification-free electrochemical detection of exosomal miRNA-21 in serum samples. Analyst. 2018;143(7):1662-9. https://doi.org/10.1039/C7AN01843F.

196. Gokce ZG, Akalın P, Kok FN, Sarac AS. Impedimetric DNA biosensor based on polyurethane/poly (m-anthranilic acid) nanofibers. Sensors Actuators B Chem. 2018;254:719-26. https://doi.org/10.1016/j.snb.2017.07.136.

197. Congur G, Eksin E, Erdem A. Impedimetric detection of miRNA-34a using graphene oxide modified chemically activated graphite electrodes. Sens Actuator A Phys. 2018;279:493-500. https://doi.org/10.1016/j.sna.2018.06.026.

198. Ebrahimi A, Nikokar I, Zokaei M, Bozorgzadeh E. Design, development and evaluation of microRNA-199a-5p detecting electrochemical nanobiosensor with diagnostic application in Triple Negative Breast Cancer. Talanta. 2018;189:592-8. https://doi.org/10.1016/j.talanta.2018.07.016.

199. Shahrokhian S, Salimian R. Ultrasensitive detection of cancer biomarkers using conducting polymer/electrochemically reduced graphene oxide-based biosensor: Application toward BRCA1 sensing. Sensors Actuators B Chem. 2018;266:160-9. https://doi.org/10.1016/j.snb.2018.03.120.

200. Benvidi A, Saucedo NM, Ramnani P, Villarreal C, Mulchandani A, Tezerjani MD et al. Electro- oxidized monolayer CVD graphene film transducer for ultrasensitive impedimetric DNA biosensor. Electroanalysis. 2018;30(8):1791-800. https://doi.org/10.1002/elan.201700654.

201. Nguyet NT, Van Thu V, Trung T, Vuong PH, Tam PD. Highly sensitive DNA sensors based on cerium oxide nanorods. J Phys Chem Solids. 2018;115:18-25. https://doi.org/10.1016/j.jpcs.2017.11.023.

202. Ehzari H, Safari M, Shahlaei M. A simple and label-free genosensor for BRCA1 related sequence based on electrospinned ribbon conductive nanofibers. Microchem J. 2018;143:118-26. https://doi.org/10.1016/j.microc.2018.07.033.

203. Mazloum-Ardakani M, Barazesh B, Khoshroo A, Moshtaghiun M, Sheikhha MH. A new composite consisting of electrosynthesized conducting polymers, graphene sheets and biosynthesized gold nanoparticles for biosensing acute lymphoblastic leukemia. Bioelectrochemistry. 2018;121:38-45. https://doi.org/10.1016/j.bioelechem.2017.12.010.

204. Divya KP, Karthikeyan R, Sinduja B, Grace AA, John SA, Hahn JH et al. Carbon dots stabilized silver-lipid nano hybrids for sensitive label free DNA detection. Biosens Bioelectron. 2019;133:48-54. https://doi.org/10.1016/j.bios.2019.03.027.

205. Jaiswal N, Pandey CM, Solanki S, Tiwari I, Malhotra BD. An impedimetric biosensor based on electrophoretically assembled $\mathrm{ZnO}$ nanorods and carboxylated graphene nanoflakes on an indium tin oxide electrode for detection of the DNA of Escherichia coli O157: H7. Microchim Acta. 2020;187(1):1. https://doi.org/10.1007/s00604-019-3921-8.

206. Zhang J, Han D, Yang R, Ji Y, Liu J, Yu X. Electrochemical detection of DNA hybridization based on three-dimensional $\mathrm{ZnO}$ nanowires/graphite hybrid microfiber structure. Bioelectrochemistry. 2019;128:126-32. https://doi.org/10.1016/j.bioelechem.2019.04.003.

207. Shamsipur M, Samandari L, Taherpour AA, Pashabadi A. Sub-femtomolar detection of HIV-1 gene using DNA immobilized on composite platform reinforced by a conductive polymer sandwiched between two nanostructured layers: a solid signal-amplification strategy. Anal Chim Acta. 2019;1055:7-16. https://doi.org/10.1016/j.aca.2018.12.013.

208. Tripathy S, Joseph J, Pothuneedi S, Das D, Vanjari SRK, Rao AN et al. A miniaturized electrochemical platform with an integrated PDMS reservoir for label-free DNA hybridization detection using nanostructured Au electrodes. Analyst. 2019;144(23):6953-61. https://doi.org/10.1039/C9AN01076A.

209. Salimi A, Kavosi B, Navaee A. Amine-functionalized graphene as an effective electrochemical platform toward easily miRNA hybridization detection. Measurement. 2019;143:191-8. https://doi.org/10.1016/j.measurement.2019.05.008.

210. Gong Q, Han H, Yang H, Zhang M, Sun X, Liang Y et al. Sensitive electrochemical DNA sensor for the detection of HIV based on a polyaniline/graphene nanocomposite. J Materiomics. 2019;5(2):313-9. https://doi.org/10.1016/j.jmat.2019.03.004.

211. Xia J, Qing J, Liu J. A sensitive electrochemical impedance DNA biosensor based on ZnO nanorod electrodes for BCR/ABL fusion gene detection. Int J Electrochem Sci. 2019;14:4271-9. https://doi.org/10.20964/2019.05.59.

212. Qian X, Qu Q, Li L, Ran X, Zuo L, Huang R et al. Ultrasensitive electrochemical detection of Clostridium perfringens DNA based morphology-dependent DNA adsorption properties of $\mathrm{CeO}_{2}$ nanorods in dairy products. Sensors. 2018;18(6):1878. https://doi.org/10.3390/s18061878. 
213. Kumari P, Adeloju SB. Fabrication of a novel DNA affinity biosensor based on hybridisation induced current by electrostatic repulsion of silicotungstic acid as a redox indicator. Talanta. 2019;194:127-33. https://doi.org/10.1016/j.talanta.2018.09.074.

214. Congur G, Erdem A. PAMAM dendrimer modified screen printed electrodes for impedimetric detection of miRNA-34a. Microchem J. 2019;148:748-58. https://doi.org/10.1016/j.microc.2019.05.040.

215. Srisomwat C, Teengam P, Chuaypen N, Tangkijvanich P, Vilaivan T, Chailapakul O. Pop-up paper electrochemical device for label-free hepatitis B virus DNA detection. Sensors Actuators B Chem. 2020;316:128077. https://doi.org/10.1016/j.snb.2020.128077.

216. Hatami Z, Ragheb E, Jalali F, Tabrizi MA, Shamsipur M. Zinc oxide-gold nanocomposite as a proper platform for label-free DNA biosensor. Bioelectrochemistry. 2020;133:107458. https://doi.org/10.1016/j.bioelechem.2020.107458.

217. Sheta SM, El-Sheikh SM, Osman DI, Salem AM, Ali O, Harraz FA et al. A novel HCV electrochemical biosensor based on a Polyaniline@ Ni-MOF nanocomposite. Dalton Trans. 2020;49:8918-26. https://doi.org/10.1039/D0DT01408G.

218. Kang SJ, Kim S, Lee K, Shin I-S, Kim Y-R. Tunable electrochemical grafting of diazonium for highly sensitive impedimetric DNA sensor. J Electrochem Soc. 2020;167(8):087504. https://doi.org/10.1149/1945-7111/ab8ce8.

219. Eksin E, Torul H, Yarali E, Tamer U, Papakonstantinou P, Erdem A. Paper-based electrode assemble for impedimetric detection of miRNA. Talanta. 2021;225:122043. https://doi.org/10.1016/j.talanta.2020.122043.

220. Alipour E, Norouzi S, Moradi S. The development of an electrochemical DNA biosensor based on quercetin as a new electroactive indicator for DNA hybridization detection. Anal Methods. 2021;13:719-29. https://doi.org/10.1039/d0ay01993c.

221. Moattari G, Izadi Z, Shakhsi-Niaei M. Development of an electrochemical genosensor for detection of viral hemorrhagic septicemia virus (VHSV) using glycoprotein (G) gene probe. Aquaculture. 2021;536:736451. https://doi.org/10.1016/j.aquaculture.2021.736451.

222. Avelino KY, Oliveira LS, Lucena-Silva N, Andrade CA, Oliveira MD. Flexible sensor based on conducting polymer and gold nanoparticles for electrochemical screening of HPV families in cervical specimens. Talanta. 2021;226:122118. https://doi.org/10.1016/j.talanta.2021.122118.

223. Shamsipur M, Samandari L, Farzin L, Besharati-Seidani A. Development of an ultrasensitive electrochemical genosensor for detection of HIV-1 pol gene using a gold nanoparticles coated carbon paste electrode impregnated with lead ion-imprinted polymer nanomaterials as a novel electrochemical probe. Microchem J. 2021;160:105714. https://doi.org/10.1016/j.microc.2020.105714. 